NBER WORKING PAPER SERIES

\title{
HOW PROGRESSIVE IS THE U.S. FEDERAL TAX SYSTEM? A HISTORICAL AND INTERNATIONAL PERSPECTIVE
}

\author{
Thomas Piketty \\ Emmanuel Saez \\ Working Paper 12404 \\ http://www.nber.org/papers/w12404
NATIONAL BUREAU OF ECONOMIC RESEARCH
1050 Massachusetts Avenue
Cambridge, MA 02138
July 2006

Thomas Piketty is Professor of Economics, Paris School of Economics (PSE), Paris, France, and a Research Fellow, Centre for Economic Policy Research, London, United Kingdom. Emmanuel Saez is Professor of Economics, University of California, Berkeley, California, and Research Associate, National Bureau of Economic Research, Cambridge, Massachusetts. Their e-mail addresses are <thomas.piketty@ens.fr $>$ and $<$ saez@econ.berkeley.edu $>$, respectively. This paper was prepared for the Fall 2006 issue of the Journal of Economic Perspectives. We are grateful to Anthony B. Atkinson and the editors of this Journal for helpful comments. The views expressed herein are those of the author(s) and do not necessarily reflect the views of the National Bureau of Economic Research.

(92006 by Thomas Piketty and Emmanuel Saez. All rights reserved. Short sections of text, not to exceed two paragraphs, may be quoted without explicit permission provided that full credit, including $\odot$ notice, is given to the source. 
How Progressive is the U.S. Federal Tax System? A Historical and International Perspective Thomas Piketty and Emmanuel Saez

NBER Working Paper No. 12404

July 2006

JEL No. H2

\begin{abstract}
This paper provides estimates of federal tax rates by income groups in the United States since 1960, with special emphasis on very top income groups. We include individual and corporate income taxes, payroll taxes, and estate and gift taxes. The progressivity of the U.S. federal tax system at the top of the income distribution has declined dramatically since the 1960s. This dramatic drop in progressivity is due primarily to a drop in corporate taxes and in estate and gift taxes combined with a sharp change in the composition of top incomes away from capital income and toward labor income. The sharp drop in statutory top marginal individual income tax rates has contributed only moderately to the decline in tax progressivity. International comparisons confirm that is it critical to take into account other taxes than the individual income tax to properly assess the extent of overall tax progressivity, both for time trends and for cross-country comparisons. The pattern for the United Kingdom is similar to the US pattern. France had less progressive taxes than the US or UK in 1970 but has experienced an increase in tax progressivity and has now a more progressive tax system than the US or the UK.
\end{abstract}

Thomas Piketty

Ecole Normale Superieure

48 Boulevard Jourdan

75014 Paris

FRANCE

thomas.piketty@ens.fr

Emmanuel Saez

University of California

549 Evans Hall \#3880

Berkeley, CA 94720

and NBER

saez@econ.berkeley.edu 
Over the last 40 years, the U.S. federal tax system has undergone three striking changes, each of which seems to move the federal tax system in the direction of less progressivity. First, there has been a dramatic decline in top marginal individual income tax rates. In the early 1960s, the statutory individual income tax rate applied to the marginal dollar of the highest incomes was 91 percent. This marginal tax rate on the highest incomes declined to 28 percent by 1988 , increased significantly to 39.6 percent in 1993, and fell to 35 percent as of 2003. Second, corporate income taxes as a fraction of gross domestic product have fallen by half, from around 3.5-4.0 percent of GDP in the early 1960s to less than 2 percent of GDP in the early 2000s (for example, Auerbach, 2006). However, corporate profits as a share of GDP have not declined during this period, suggesting that capital owners - who are disproportionately of aboveaverage incomes -- get to earn relatively more net of taxes today than in the 1960s. Third, there has been a substantial increase in payroll tax rates financing Social Security retirement benefits and Medicare. The combined employeeemployer payroll tax rate on labor income has increased from 6 percent in the early 1960s to over 15 percent in the 1990s and 2000s. Moreover, the Social Security payroll tax applies only up to a cap--equal to $\$ 90,000$ of annual earnings in 2005--and is therefore a relatively smaller tax burden as incomes rise above the cap.

However, the conclusion that these three changes have reduced the progressivity of the federal tax system less obvious than it may at first appear. For example, in the case of the individual income tax, the numerous deductions and exemptions mean that the tax rates listed in the tax tables might be a poor measure of the actual tax burden faced by each income group. In addition, some forms of income, such as capital gains, have traditionally faced lower tax rates, which benefits disproportionately high income taxpayers. In the case of the corporate income tax, there are competing theories about who bears the burden of the tax: for example, does it reduce returns for stockholders, or reduce the returns on other assets such as bonds or pensions of future retirees, or is it paid 
by workers in the form or lower wages, or is it paid by consumers in the form of higher prices?

We begin this paper by using the large public micro-file tax return data to estimate the current progressivity of the U.S. federal tax system, which essentially includes individual and corporate income taxes, estate taxes, and payroll taxes. We will lay out what we think are the most plausible and simple assumptions about the incidence of taxes based on previous work. We will then look at trends in the progressivity of the U.S. tax system from 1960 to the present. Throughout this discussion, we will pay particular attention to small groups at the top of the income distribution, who often represent a significant fraction of aggregate income and aggregate taxes paid, and who often face tax rules that have their main impact at the top of the income distribution. Government agencies such as the Internal Revenue Service (IRS) and the Congressional Budget Office (CBO) produce annual statistics on tax progressivity in the United States. Our approach differs from the IRS statistics (Parisi, 2004-05; Strudler et al., 2005), because those IRS statistics ignore other federal taxes such as the corporate income tax, the estate tax, or payroll taxes. Our approach differs from the CBO statistics (CBO, 2001) because we focus primarily on top incomes while they focus primarily on income quintiles. ${ }^{1}$ Our approach also differes from classic comprehensive studies of tax progressivity like Pechman and Okun (1974), Pechman (1985), or Kasten et al. (1994), because our more basic method does not incorporate state and local taxes, and we ignore government transfers. However, we provide progressivity results for over 40 years, while previous studies have focused on a few years at most. We will then contrast the U.S. results with the experience from other countries. Using a similar (if simplified) methodology, we will present progressivity results for the tax systems of France and the United Kingdom. 


\section{Current Federal Tax Progressivity in the United States}

The definition of a progressive tax system usually starts with the idea of a proportional tax, in which everyone pays the same share of income in taxes. From that baseline, a progressive tax is when the share of income paid in taxes rises with income, and a regressive tax is when the share of income paid in taxes falls with income. Of course, real-world tax codes are complex and full of rules that have different effects across the income distribution. Thus, a more general definition is that a tax system can be defined as progressive if after-tax income is more equally distributed than before-tax income, and regressive if after-tax income is less equally distributed than before-tax income.

Inequality and tax progressivity have many facets and should be explored along different measures depending on the specific issue one wants to examine. For example, an analyst can look at the impact of taxes on the poverty rate or on a measure of inequality like the Gini coefficient. In this paper, we will focus on top income shares, defined as how the tax code affects the fraction of total income going to a given group in the income distribution, such as the top decile or top percentile. $^{2}$

We begin with estimates of the progressivity of the U.S. tax code in 2004. More precisely, we use data on incomes for the year 2000, which is the most recent year for which detailed micro data on types of income is available. We adjust for nominal and real growth to 2004 dollars, and then apply the tax code as it stood in 2004 .

Income Groups

\footnotetext{
${ }^{1}$ The department of Treasury and the Joint Committee on Taxation also produce distributional analyses to evaluate tax reforms. Their distributional analyses are close to those of CBO (see CBO, 2001).

${ }^{2}$ The after-tax income share is equal to before-tax income share times the ratio of one minus the tax rate for the given group to one minus the average tax rate across the full distribution. Or in algebraic terms: after-tax income share $=$ before tax income share ${ }^{*}$ (1-average tax rate for the group $) /(1$ - average tax rate economy wide).
} 
The first column of Table 1 displays the groups we are considering according to the percentile of income, ranging from the second quintile (Percentile 20-40) to the top 0.01 percent (P99.99-100). We exclude the bottom quintile (P0-20) from the analysis because many low income earners have zero market income and receive only government transfers such as Social Security or Disability income, and do not file income tax returns. Groups are based on "tax units". A tax unit is defined in the U.S. tax code as a married couple or a single person, with their dependents if they have any. The total number of tax units in 2004 is 144 million and is taken from Piketty and Saez $(2003,2006)$. It is estimated from census data as the sum of all adults (aged 18 and above in the U.S. population) less all married women. In other words, this is the total number of tax units in the United States if every family had been required to file an individual tax return. In recent decades, about 90 to 95 percent of tax units file a tax return. Non-filers have in general very low incomes and they owe little or no income tax.

The average income for each group of tax units is shown in column 2. Income is defined as all sources of market income reported on income tax returns. This includes wages and salaries (before employer and employee Social Security and Medicare payroll taxes are deducted), bonuses and exercised stock-options, employer and private pensions, self-employment income, business income, dividends, interest, and rents, as well as realized capital gains. ${ }^{3}$ We also exclude all government transfers such as Social Security retirement and disability benefits, government-provided health benefits (Medicare and Medicaid), unemployment and workers compensation, and all cash and in-kind welfare

${ }^{3}$ Because realized capital gains are not an annual regular stream of income and tend to be realized by individuals in a lumpy way once every few years, we rank tax units based on income excluding realized capital gains when we define the income fractiles. We then add back realized capital gains to the incomes of each of those income groups (Piketty and Saez, 2003 use the same definition for one set of their top income share series). Ranking individuals based on income including capital gains would make the individual income tax look less progressive as capital gains have generally received a favorable treatment. 
programs. Our admittedly simple approach sidesteps a number of issues about how to measure income appropriately: for example, our income measure does not include the value of imputed rent for homeowners and does not exclude interest payments on debts such as mortgages or consumer credit. Our income measure also excludes non-taxable benefits such as employer provided health care. At the end of this section, we offer some further discussion of conceptual issues that can arise in measuring income. We use the large publicly available micro dataset of individual tax returns produced by IRS, available most years from 1960 to 2001 to estimate individual income and construct our various income fractiles. Full details on our estimation methodology, as well as a comparison with estimates from previous contributions, are reported in appendix.

\section{Taxes, Tax Rates, and Tax Incidence}

We consider four federal taxes: the individual income tax, the corporate income tax, the estate (and gift) tax, and the payroll tax financing disability, retirement, and health benefits for the elderly. Those four federal taxes represent over 90 percent of all federal taxes. The remaining federal taxes are primarily excise taxes like those on gasoline, alcohol and tobacco and various other small taxes such as stamp duties.

The federal individual income tax is the largest tax, typically collecting 710 percent of GDP in most years since the 1960s. Individual income taxes declined sharply from 2000 to 2004 following the tax cuts of the Bush administration, falling from 10.3 percent of GDP in 2000 to 7.0 percent of GDP in 2004. The payroll tax financing Social Security and Medicare has increased significantly, climbing from about 2 percent of GDP in the 1960s to 6.4 percent of GDP by 2004 . The corporate income tax has shrunk dramatically: it was typically 3.5-4.0 percent of GDP in the 1960s, but had fallen to 1.6 percent of GDP by 2004. The estate and gift tax has always been very small relative to the other taxes, although it is important for distributional analysis because it 
disproportionately affects those with higher incomes. The estate tax collected about 0.6 percent of GDP in the 1960s, and 0.25 percent of GDP in 2004.

Columns 3 to 6 display the average (not the marginal) tax rate for each of the four federal taxes we are considering; that is, what share of income for that group was collected by that tax in 2004. Column (7) displays the sum of the average tax rate of all four taxes combined.

We use the TAXSIM calculator developed at the National Bureau of Economic Research (Coutts and Feenberg, 1993) to compute federal individual income taxes.

Payroll taxes are by definition paid based on wages and salaries and shared between employers and employees. This distinction is in principle irrelevant. We assume that both the employer and employee payroll tax is paid by the wage earner, so that for most employees in recent years, the federal payroll tax rate is $15.3 \%$ (and not $7.65 \%$ ).

We will assume that the corporate income tax falls entirely on capital income and that all financial assets (and not only corporate stock) bear the tax equally. Auerbach (2006) summarizes the literature on the incidence of the corporate income tax and points out that there is still considerable uncertainty on the question because of the inherent difficulty in measuring empirically the economy-wide incidence of the corporate tax. Our assumption that the corporate income tax falls on capital income in general can be seen as a middle-ground assumption between two scenarios. In one scenario, the corporate income tax falls solely on shareholders. Because corporate stock ownership is more concentrated than wealth ownership in general, the corporate income tax would look more progressive under this scenario. In the other scenario, the corporate tax is shifted on to labor income, either in the form of reduced wages or increased commodity prices. Because capital income is more concentrated than labor income, the corporate income tax would look less progressive under this scenario. ${ }^{4}$

\footnotetext{
${ }^{4}$ The increased openness of the US economy might have shifted the corporate tax more toward labor income, which would accentuate the trends we document here.
} 
The federal estate tax is paid based on total net worth of the decedents after various exemptions such as spousal bequests and charitable donations. Only net estates larger than $\$ 1.5$ million in 2004 are liable for the estate tax. As a result, only about 1 percent of all adult decedents are liable for the estate tax in 2004. We use IRS published tabulations reporting the number of estates and estate taxes paid by size of estate to estimate the amount of taxes paid by each fractile of decedents (relative to the total number of adult deaths). We then assume that those taxes are borne by the corresponding fractile of tax units. This basic method is valid to the extent that ranking by income is relatively close to ranking by wealth at the top of the distribution.

\section{How Taxes Affect the Income Distribution}

Column 8 of Table 1 displays the share of pre-tax income for each group. Column 9 displays the share of post-tax income for each group. These statistics illustrate several themes. First, the federal tax system as a whole was progressive in 2004. The post-tax share of income is higher than the pre-tax share of income for those income groups that are lower in the income distribution; conversely, the post-tax share of income is lower than the pre-tax

share of income for the groups highest in the income distribution, above the $90^{\text {th }}$ percentile. Second, the statistics show that, even though the very top groups are very small in terms of number of families, they represent a large share of income earned, and an even larger share of total taxes paid. For example, the upper half of 1 percent of the income distribution earned 15.6 percent of total, and paid 22.5 percent of all federal taxes.

\section{Some Caveats}

The calculations presented in Table 1 sidestep or ignore a number of issues. We mention seven of those issues here.

First, government transfers, such as welfare programs, accrue disproportionately to the bottom of the income distribution and also reduce inequality in disposable income. Conceptually, transfers should be included (as a 
negative) in the tax rates to estimate the full redistribution carried out by the government through taxes and transfers. However, as our focus in this paper will primarily be on the top of the income distribution, and since transfers represent a very small fraction of middle and high-income earners incomes, ignoring transfers has little impact on our results.

Second and related, there is an argument that the payroll taxes that finance Social Security benefits should not be treated as a pure tax because Social Security benefits depend on payroll taxes paid. In principle, one would want to subtract the value of future Social Security benefits from payroll taxes paid on an individual basis and consider only the pure tax component of the tax. For simplicity, we count the entire payroll tax financing Social Security as a tax. ${ }^{5}$ Social Security benefits are overall progressive (the progressive benefits formula more than compensates for the lower life expectancy of lower income groups, Liebman, 2002). Hence, taking into account Social Security benefits would make the Social Security payroll tax look less regressive but would not affect much top income groups.

Third, we focus on annual incomes, which are not a perfect measure of permanent income over the course of a lifetime. Several studies have shown that, because of year-to-year transitory fluctuations in income, progressive individual income taxes appear less progressive from a lifetime perspective than from an annual perspective (for example, Fullerton and Rogers, 1993). However, there is also substantial evidence that consumption tracks income closely, either because households face borrowing constraints or because they do not plan according to the classic inter-temporal utility model (Akerlof, 2005). Thus, the best measure of economic affluence is probably in between the extreme cases of the annual perspective and the lifetime perspective. Measuring lifetime income requires longitudinal data, but there are no publicly available longitudinal data

\footnotetext{
${ }^{5}$ Medicare benefits are independent of payroll tax contributions, and hence the Medicare payroll tax is a pure tax.
} 
that do a good job of the very top of the U.S. income distribution. In this paper, we focus solely on the annual perspective. ${ }^{6}$

Fourth, our analysis ignores behavioral responses to taxation such as tax avoidance, reduction in labor supply or savings due to taxation. Those behavioral responses create an excess burden on taxpayers over and above the taxes paid; Fullerton and Rogers (1993) build a general equilibrium model where they estimate total tax burdens, including excess burdens. However, economists have substantial disagreement on the size of behavioral responses to taxation, and so considering the basic case with no behavioral response is a useful starting place.

Fifth, we ignore untaxed income, which is especially important in the case of in-kind employer benefits such as health care insurance and the imputed rent of homeowners. ${ }^{7}$ Health benefits and pensions accrue disproportionately (relative to income) to the middle and upper middle class and would reduce estimated average tax rates for those groups. However, this would probably not affect much the time series analysis for top groups.

Sixth, a number of issues arise in thinking about the treatment of capital gains. In our approach, capital gains serve as a way of counting corporate income. After all, retained earnings are reflected in the stock prices and will be part of our income definition when capital gains are realized on those stocks. In the long-run and in the aggregate, realized capital gains on corporate stock reported on individual tax returns are of comparable magnitude to retained earnings from corporations estimated in national accounts. Realized capital gains (or equivalently retained earnings) are net of corporate income taxes. Because we include corporate income taxes in the analysis, we need to add back corporate income taxes to income (see e.g., Feldstein, 1988). There are also issues regarding what portion of capital gains should be counted as income, and when it should be counted. In principle, capital gains should be counted as

\footnotetext{
${ }^{6}$ Kopczuk, Saez, and Song (2006) show that mobility has been quite stable within top wage income groups since the 1950s suggesting taking a longer term perspective for measuring income would probably not bias the trend of declining progressivity that we document here.

7 Similarly, our income measure excludes contributions to employer pensions (either defined benefits or defined contribution pensions), but we do include employer pensions when they are
} 
income when they accrue rather than when they are realized. However, our income measure includes only realized capital mainly because unrealized gains are difficult to observe. ${ }^{8}$ Also, there is an argument in principle for adjusting capital income for inflation and only counting real gains as income, both in the case of capital gains and in the case of interest income (Feldstein, 1988). We do not attempt such a correction here.

Finally, we ignore state and local taxes in this study. Federal taxes represent about two-thirds of all U.S. taxes, the remaining third are state and local taxes. State and local taxes in the United States are primarily of three types. First, state income taxes (individual and corporate) tend to be progressive and are about 25 percent of state and local tax revenues on average. ${ }^{9}$ Second, property income taxes, primarily on residential real estate, are about 30 percent of state and local tax revenue. Property taxes are progressive if incidence falls primarily on property owners, but become regressive if they are shifted on rents. Third, sales and excise taxes, which are regressive as lower income families spend a larger fraction of their income on taxed consumption goods, are about 35 percent of state revenue. Overall, state and local taxes are believed to be somewhat regressive but this depends on the assumed incidence of the property tax. If the property tax is assumed to fall on owners of capital, then overall, Pechman (1985) shows that state and local taxes are very close to being proportional to income across income groups. In that case, ignoring state and local states would be of no consequence when assessing overall tax progressivity.

received. Thus, our pension income measure, like our measure of capital gains, can be viewed as based on realization rather than accrual

${ }^{8}$ Capital gains are never realized on individual tax returns if the assets are transferred at death or through inter-vivos gifts. Poterba and Weisbenner (2001) estimate that, in 1998, such capital gains on transferred assets represent about 35 percent of the value of gross estates reported on estate tax returns. The fraction of never realized gains passed at death for financial assets are small relative to realized capital gains reported on individual tax returns and are ignored in this study.

${ }_{9}^{9}$ State income taxes can be deducted as an itemized deduction from income for federal income tax purposes. As we do not include state taxes in our analysis, we have also not deducted state taxes in our individual income tax TAXSIM computations. 


\section{U.S Trends in Federal Tax Progressivity}

To examine the evolution of U.S. federal tax progressivity over time, it is necessary to look at the patterns of how the tax code has evolved over time and how sources and size of income - especially for the very top of the income distribution - have evolved over time.

\section{Federal Tax Rates Over Time}

Figure 3 displays the average federal tax rate paid in 1960 and 2004 for various groups along the income distribution. Again, as in Table 1, because the latest IRS micro data is only available until year 2001 (before most of the recent tax cuts took place), we report tax rates based on 2004 tax law, applied to incomes reported in 2000 and adjusted for nominal and real growth.

The federal tax system is clearly progressive. In 2004, the average tax rate increases smoothly with income from less than 10 percent in the second quintile (P20-40) to around 35 percent at the very top. In that year, the average tax rate increases only modestly from 30 percent in the bottom half of the top percentile (P99-99.5) to 35 percent at the very top (P99.99-100), suggesting that the current federal tax system is relatively close to a flat tax rate within the top 1 percent (incomes above around $\$ 300,000$ in 2004).

The figure also shows how the total federal tax rate is decomposed into individual income tax, payroll tax, corporate income tax, and estate tax average rates. The individual income tax is the main component driving progressivity in 2004. The average individual tax rate is actually negative at the bottom of the income distribution (primarily because of the refundable Earned Income tax Credit) and increases to an average rate of over 25 percent at the very top. The progressivity of the federal income tax is due to the increasing structure of marginal tax rates coupled with exemptions and credits, which benefit lower incomes disproportionately. The average tax rate, however, remains substantially below the top marginal tax rate of 35 percent even at the very top, because of lower tax rates on long-term capital gains and dividends (a 15 percent maximum 
rate) and, to a lesser extent, deductions for mortgage interest payments and charitable contributions.

The corporate income tax and the estate tax are also progressive in 2004: - they increase from a combined average rate of less than 2 percent at the bottom of the income distribution to about 7 percent at the very top - but are small relative to the individual income tax. Those two taxes are progressive because capital income is concentrated at the top of the income distribution. The estate tax also has a very progressive structure coupled with very large exemptions, so that less than 1 percent of adults who die are liable to pay any estate tax. Finally, the payroll tax is regressive, involving an average tax rate of about 11 percent of total income below the top decile and declining to about 1 percent at the very top. This is due to the cap in the Social Security payroll tax (above $\$ 87,900$ in 2004) and the fact that labor income is a smaller fraction of total income at the top than in the middle of the distribution.

The contrast between the progressivity of federal taxes in 2004 and in 1960 is striking, as shown in Panel B in Figure 3. In 1960 federal tax system imposed higher average tax rates on those with low incomes, then lower rates on a middle group up to the $95^{\text {th }}$ percentile, and much higher rates within the top 5 percent of the income distribution, especially in very top groups. The lower tax burden in 1960 for the middle groups is largely due to the fact that the payroll tax, which falls primarily on the groups from P20 to P95, was much smaller in 1960 than today. The 1960 federal tax system was very progressive even within the top percentile with an average tax rate of around 35 percent in the bottom half of the top percentile to over 70 percent in the top 0.01 percent. This finding illustrates the theme that it is important to decompose the top of the income distribution into very small groups in order to capture the progressivity of a tax system. Although very top groups contain few taxpayers, they account for a substantial share of income earned, and an even larger share of taxes paid.

Interestingly, the larger progressivity in 1960 is not mainly due to the individual income tax. The average individual income tax rate in 1960 reached an average rate of 31 percent at the very top, only slightly above the 25 percent 
average rate at the very top in 2004 . Within the 1960 version of the individual income tax, lower rates on realized capital gains, as well as deductions for interest payments and charitable contributions, reduced dramatically what otherwise looked like an extremely progressive tax schedule, with a top marginal tax rate on individual income of 91 percent.

The greater progressivity of federal taxes in 1960, in contrast to 2004, stems from the corporate income tax and the estate tax. The corporate tax collected about 6.5 percent of total personal income in 1960 and only around 2.5 percent of total income today. Because capital income is very concentrated, it generated a substantial burden on top income groups. The estate tax has also decreased from 0.8 percent of total personal income in 1960 to about 0.35 percent of total income today. As a result, the burden of the estate tax relative to income has declined very sharply since 1960 in the top income groups.

Table 2 displays the pattern of federal average tax rates for different income groups in $1960,1980,1990,2000$, and the projection for 2004. The table shows a flattening of the tax rate structure. In 1960, average taxes collected were fairly flat up from the $20^{\text {th }}$ the $90^{\text {th }}$ percentile, and then rose sharply. By 1980 , average taxes collected from the very top income groups, especially within the top percentile, had declined sharply, while average tax rates collected from between the $40^{\text {th }}$ and 95th percentiles had risen. From 1980 to 1990 , tax rates at the top declined, while tax rates in the middle class stayed constant. In the 1990s, tax rates increased only within the top 5 percent. The 2004 projected tax rates restore lower rates of 1990 at the top and reduce tax rates on the middle class below the levels of 1980,1990 , or 2000.

\section{Income and Taxes At the Top of the Income Distribution}

The changes in progressivity of the income distribution since 1960 have been most marked at the very top of the income distribution, which as Table 1 illustrated, accounts for a substantial share of total income. Piketty and Saez (2003) document the evolution of the incomes of those at the very top of the 
income distribution. Figure 2 displays the total share of income received by the top 0.1 percent of the income distribution and its composition.

Two important facts stand out. First, the share of income going to the top 0.1 percent of the income distribution has grown tremendously since the late 1970s: the share of total income received by the top 0.1 percent was around 2.5 of total income in the 1970s and reached a peak above 9 percent of total income 2000. In fact, most of the overall increase in the inequality of income has been driven by the very top of the income distribution. The U.S. Bureau of the Census reports, using a somewhat different definition of income than ours, that the top quintile of the income distribution received 43-44 percent of all income in the 1970s, but this share had increased to about 50 percent by 2001. Piketty and Saez (2003) show that most of the relative income gains for the top quintile have been concentrated within the top 1 percent -- and especially the top 0.1 percent - with relatively modest gains in the top decile excluding the top percentile (P9095 and P95-99).

Second, the composition of top incomes has changed substantially. Figure 2 shows the breakdown into wage income, business income, capital income, realized capital gains, and imputed corporate taxes. In the 1960s, top incomes were primarily composed of capital income: mostly dividends and capital gains. The surge in top incomes since the 1970s has been driven in large part by a steep increase in the labor income component, due in large part to the explosion of executive compensation. As a result, labor income now represents a substantial fraction of income at the top. This change in composition is important to keep in mind, because the corporate and estate taxes that had such a strong effect on creating progressivity in the 1960s would have relatively little effect on labor income.

Figure 3 shows how the progressivity of the federal income tax system has mitigated income concentration since 1960. Panel A displays the share of total income received by the top 0.1 percent of the distribution before and after all federal taxes. Panel A shows that the federal tax system reduced income concentration the most in the 1960s and 1970s when income concentration was 
relatively low, and that the federal tax system has a relatively modest effect on the top 0.1 percent income share in recent years when income inequality has become higher. To put it another way, the pre-tax share of income for the top 0.1 percent rose from 2.6 percent in 1970 to 9.3 percent in 2000 . The rise in after-tax income shares was from 1.2 percent in 1970 to over 7.3 percent in 2000. In percentage point terms, the increase in pre-tax incomes is slightly greater than the increase in post-tax incomes. But in terms of observing what those with very high incomes can afford to consume, the after-tax share of income for those in this income group multiplied by a factor of 6.1 , while the pre-tax share of income multiplied by a factor of 3.5. The tax reductions enacted in 2001 and 2003 have further weakened the redistributive power of the federal income tax today. ${ }^{10}$

When the pattern of redistribution is broken down into different taxes, an expected pattern emerges. The overall extent of redistribution from the very top of the income distribution was higher in the 1960s, mainly because of the impact of the corporate income tax and the estate tax. In more recent years, as the relative magnitude of the corporate and estate taxes has diminished and as average income tax rates have dropped a great deal at the bottom of the income distribution, the income tax has become the primary element of progressivity that is, creating a gap between pre-tax and post-tax income for those at the highest income levels -- in the overall federal tax code.

Panel B of Figure 3 displays the average tax rate of the top $0.1 \%$ (on the left axis) and shows that most of the decline was concentrated in a relatively brief period from 1976 to 1988 when the average rate dropped from over $60 \%$ to $35 \%$. The share of taxes paid by various income groups is sometimes used as a measure of progressivity, but this measure is improper and misleading. Panel B

10 It is a disputed question whether the surge in reported top incomes has been caused by the reduction in taxation at the top through behavioral responses. There is clear evidence of short-term responses to changes in tax rates through retiming of income realization or shifts from the corporate to the individual tax base. Demonstrating a long-term causal relationship from top tax rates to more economic activity at the top, and especially the surge in top wage compensation is almost impossible (Saez, 2004). It is conceivable that causality might have run in reverse way and that non-tax forces generated an increase in income concentration and that top income earners were able to use their greater incomes to influence the political process and obtain a reduction in tax progressivity subsequently. 
also shows the fraction of total taxes paid by the top $0.1 \%$ income group (on the right axis). The share of taxes paid is given by

Top $0.1 \%$ share of tax $=$ Top $0.1 \%$ tax rate * Top $0.1 \%$ income share/ Average tax rate.

Panel A shows that the share of income received by the top 0.1 percent has risen dramatically over several decades, and it is not surprising the see that indeed the share of tax series follows the income share series. But although the share of tax paid by the top 0.1 percent of the income distribution has increased substantially over the last 30 years, the average tax rate of the top $0.1 \%$ has declined substantially over that same time. When the share of income received by the top income groups is changing, the share of tax paid by those top income groups is a misleading method for evaluating the progressivity of the tax system.

\section{International Perspectives}

In this section, we apply the same methodology to France and the United Kingdom, and we compare the resulting patterns of effective tax rates for 1970 and a recent year with those obtained for the United States. ${ }^{11}$ The top half of displays the average tax rates in all three countries across income groups for 1970; the bottom half of the table shows the results for a recent year: 2005 in France, 2004 in the United States, and 2000 in the United Kingdom. The table also shows how those tax rates are broken down into individual income taxes, payroll taxes, and estate and wealth taxes. We did not include the corporate tax in the French and British analysis because it would have required a much more in depth analysis. However, in contrast to the United States, the ratio of corporate

\footnotetext{
${ }^{11}$ The estimates presented for France and the U.K. rely on a number of simplifying assumptions which are presented in the technical appendices to the working paper version Piketty and Saez 2006). In particular, we exclude the large value added taxes and excise taxes from our French and U.K. estimates which are slightly regressive. Those taxes constitute about one third of tax revenue in those countries. As France and the U.K. have very small local taxes, this indirect tax
} 
taxes to has been fairly stable in France and the United Kingdom since 1960, suggesting that including the corporate tax would not alter the direction of change in tax progressivity in those countries. The British results build upon the top income share series and individual tax rate series built by Atkinson (2006) and the French results build upon Piketty (2003).

Three key findings emerge from our international perspective. First, in all three countries, individual income tax progressivity has declined substantially since 1970. The decline has been particularly sharp in the United Kingdom, where the average share of income collected by income tax for fractile P99.95100 dropped from over 69 percent to less than 35 percent in 2005. In contrast to the United States, the very high British top marginal rates prevailing in 1970 were not tempered by tax deductions and tax loopholes.

In recent years, individual income tax burdens incurred by top income groups are virtually identical in all three countries today, with average tax rates around 30 percent at the very top. In particular, contrarily to popularly-held beliefs, effective individual income tax rates currently incurred by top income groups are smaller in France than in Anglo-Saxon countries. At fractile P99-99.5, the average income tax rate was only 11.6 percent in France as of 2005, as compared to 21.4 percent in the United States and 27.4 percent in the United Kingdom. That is, most high-wage individuals currently pay a substantially higher share of their income in the form of individual income taxes in the United States or in the United Kingdom than in France. The statutory top marginal rate is currently 48 percent in France, versus 35 percent in the United States and 40 percent in the United Kingdom. ${ }^{12}$ But the higher top marginal tax rates in France are largely undone by the large base exemptions and tax deductions that have always characterized the French individual income tax system. Also, the share of French taxpayers facing these very high marginal rates is relatively low. The last columns of the recent data show that the share of income received by the top 0.5

exclusion is thus comparable to excluding the local and state taxes in the U.S. case, which are also seen as slightly regressive. 
or 0.1 percent of the income distribution in France is much smaller than in the United States or the United Kingdom.

In 1970, the progressivity of the tax code taken as a whole was unambiguously smaller in France than in the United Kingdom or the United States. For example, the top .01 percent of the distribution paid 75 percent of income in taxes in the United States in 1970 over 90 percent of income in taxes in the United Kingdom, but only 48.8 percent of this group's total income went to taxes in France. During most of the post-war period, income tax progressivity has been substantially larger in Anglo-Saxon countries than in France and most other continental European countries. For example, Dell (2006) presents an analysis of Germany, which appears fairly close to France.

This pattern illustrates a general point made by Lindert (2004): countries in which government spending is a fairly high share of GDP have always relied on a mix of taxes that create relatively low distortion, with less progressivity, large exemptions for capital income, and so on. Meanwhile, Anglo-Saxon countries in which government spending is a relatively low share of GDP have historically relied on more progressive taxes. According to Lindert, this pattern is the key reason why the huge rise of social transfers in high government-spending countries such as France did not generate large efficiency losses and hence reductions in aggregate growth. Although Lindert's point holds true if one adopts a long-run perspective, the novelty from the recent decades is that Anglo-Saxon countries have gone through a series of significant top rate cuts since the 1970s, and have converged (and overshot) towards the average of the OECD countries in terms of the progressivity of their overall tax code.

A second major finding from Table 2 is that the payroll tax burden has increased substantially over the 1970-2005 period in all three countries. The rise in payroll tax burden has been particularly large in France. As of 2005, the employee payroll tax is 22.5 percent of gross wages in France, and the employer payroll tax is 42.5 percent. In practice, this means that the total labor cost

\footnotetext{
${ }^{12}$ Estimates for France were computed using 2005 tax law, and did not take into account the new income tax cuts recently announced by the French government (the top marginal rate is
} 
corresponding to a net wage of 77.5 is as large as 142.5 (and the income tax then applies to the remaining 77.5). In France in 1970, the employee and employer payroll tax rates were respectively 8.2 percent and 32.8 percent of gross wages. Moreover, most payroll taxes were capped in 1970, and most have been gradually uncapped between 1970 and 2005 and now apply to all wages, including very top wages.

As all internationally-mobile high-wage earners should know, the reason why the overall tax burden is on average much higher in France than in AngloSaxon countries has little to do with the individual income tax, and a lot to do with the many social contributions levied through payroll taxation. However, because very top incomes are disproportionately composed of business and capital income rather than wage income (and especially so in France), the overall impact of payroll taxation on tax progressivity is regressive. In France, as of 2005, the regressivity of the payroll tax system undoes the progressivity of the individual income tax system, so that the resulting tax system is basically flat. The last two columns of Table 2 for France in 2005 show that the pre-tax and post-tax shares of income in France are almost the same. For instance, the combined income and payroll average tax rate is 36.6 percent at the level of fractile P0-90 (1.8 percent income tax, 34.8 percent payroll tax), and 37.3 percent at the level of fractile P99.99-100 (28.8 percent income tax, 8.5 percent payroll tax). Of course, the overall picture of how government affects the distribution of income would look substantially different if we were to look at the benefits side, which are not taken into account in this paper, and not only at the tax side.

The third key conclusion emerging from our international perspective is that in spite of the parallel evolutions of income and payroll tax components, overall tax progressivity has not evolved in the same way in all three countries during the 1970-2005 period. Figure 6 illustrates this by displaying the (full) average tax rates across income groups in the three countries in 1970 (Panel A) and more recently (Panel B). In this case, however, we show the bottom 90 percent of the income distribution grouped together, while separating out the 
percentiles above which make such a substantial difference to productivity. Progressivity of the overall tax code has unambiguously declined in the United States and in the United Kingdom. The average share of income paid by those at the very top of the income distribution has dropped substantially. However, progressivity in the overall French tax code did not change much from 1970 to 2005 , and may even have increased somewhat, especially at the very top end of the distribution. This is due to a combination of two factors: the estate tax and the wealth tax. First, while the impact of the estate tax on progressivity has declined enormously in the United States and in the United Kingdom, it has increased in France. The progressivity of estate taxation has always been fairly moderate in France, just as in a number of continental European countries such as Germany, especially for estates transmitted to spouses and children (so-called "direct line" estates). The top marginal estate tax rate was only 20 percent in France until 1983, when it was raised to 40 percent. In contrast, the top marginal estate tax rate in the United States and in the United Kingdom was above 70 percent during most of the post-World War II period, and was gradually reduced since the 1980s. As a consequence, the contribution of estate taxation to overall tax progressivity has declined substantially in the United States and in the United Kingdom between 1970 and 2005, while it has increased somewhat in France.

The other important factor is the creation of a wealth tax in France following the 1981 election, which brought a socialist party to power. France then repealed the wealth tax in 1986 and re-introduced it in 1989. It is now levied on the top 1 percent wealth holders, with a top marginal rate of 1.8 percent on wealth above 15 millions euros (or approximately $\$ 20$ million U.S. dollars). As one can see from Table 2, the contribution of the wealth tax to overall tax progressivity is sizeable. The wealth tax pushes the effective average taxes above 60 percent in France in 2005. This level of average taxation for groups at the very top of the income scale in France in 2005 is still far less than the levels observed in 1970 in the United States and in the United Kingdom for the very top groups. Thus, the French socialist governments of the 1980s-1990s are 
supporters of progressive taxation, but less so than the Democrat and Labor Anglo-Saxon governments of the 1950s-1960s.

Although these comparative results for the United States, France and the United Kingdom results rely on incomplete and exploratory estimates, we believe they illustrate several points. First, to assess progressivity of an overall tax system, it is critical to take a broad view of the tax system. Without taking estate and wealth taxation into account, it would not be apparent that tax progressivity has increased somewhat in a country like France between 1970 and 2005, while it has declined enormously in the United Kingdom and in the United States. Second, these findings suggest show that Lindert's (2004) law is either about to change or has already done so. That is, Anglo-Saxon countries with relatively low levels of government spending relative to GDP used to have a more progressive tax system than high-spending welfare states. However, today, a high-spending welfare state like France seems to display both higher average tax rates and higher tax progressivity. This interesting issue deserves further research. In particular, one would need to look at a much broader set of countries, especially from the viewpoint of intra-European tax competition, and to develop more systematic and rigorous methodologies encompassing a broader set of taxes.

\section{Conclusion}

This paper has discussed the progressivity of the U.S. federal tax system, its evolution since 1960, and how it compares with other countries. Several important findings emerge.

First, the progressivity of the U.S. federal tax system at the top of the income distribution has declined dramatically since the 1960s. For example, the top 0.01 percent of earners paid over 70 percent of their income in federal taxes in 1960, while they paid only about 35 percent of their income in 2005. Average federal tax rates for the middle class have remained roughly constant over time. This dramatic drop in progressivity at the upper end of the income distribution is due primarily to a drop in corporate taxes and to a lesser extent estate and gift 
taxes which fall on capital income combined with a sharp change in the composition of top incomes away from capital income and toward labor income. The reduction in top marginal individual income tax rates has contributed only marginally to the decline of progressivity of the federal tax system, because with various deductions and exemptions, along with favored treatment for capital gains, the average tax rate paid by those with very high income levels has changed much less over time than the top marginal rates. These large reductions in tax progressivity since the 1960s took place primarily during two periods: the Reagan presidency in the 1980 s and the Bush administration in the early 2000 s. The only significant increase in tax progressivity since 1960 took place in the early 1990s during the first Clinton administration.

Second, the most dramatic changes in the federal tax system progressivity almost always take place within the top 1 percent of income earners, with relatively small changes occurring below the top percentile. For example, many of the recent tax provisions that are currently hotly debated in Congress, such as whether there should be a permanent reduction in tax rates for capital gains and dividends, or whether the estate tax should be repealed, affect primarily the top percentile of the distribution - or even just an upper slice of the top percentile. This pattern strongly suggests that, in contrast to the standard political economy model, the progressivity of the current tax system is not being shaped by the selfinterest of the median voter. ${ }^{13}$

Third, international comparisons confirm that is it critical to take into account other taxes than the individual income tax to properly assess the extent of overall tax progressivity, both for time trends and for cross-country comparisons. We hope that the preliminary international comparisons presented in this paper will contribute to stimulate more systematic comparative research in this area.

\footnotetext{
${ }^{13}$ Permanent reductions in dividend and capital gains combined with a repeal in the estate tax would certainly reduce the current progressivity of federal taxes and favor large wealth holders. The Alternative Mininum Tax, which is not indexed for inflation and hits more and more tax filers, will mostly increase tax burdens on the upper middle class but will not affect much the top $0.1 \%$.
} 


\section{References}

Akerlof, George A., (2005) "The Missing Motivation in Macroeconomics", Presidential Address, American Economic Association, 2007, preliminary draft.

Atkinson, Anthony B. (2006) "The Distribution of Top Incomes in the United Kingdom 1908-2000", in Eds. A. B. Atkinson and T. Piketty, Top Incomes over the Twentieth Century: A Contrast Between European and English Speaking Countries, Oxford: Oxford University Press.

Auerbach, Alan (2006) "Who Bears the Corporate Tax?", in Ed. J. Poterba Tax Policy and the Economy 20, Cambridge: the MIT Press.

Congressional Budget Office, (2001) Effective Federal Tax Rates, 1979-1997, U.S Government Printing Press: Washington DC (annual updates available online).

Dell, Fabien (2006), "The Distribution of Top Incomes in Germany, 1890-2000", in Eds. A. B. Atkinson and T. Piketty, Top Incomes over the Twentieth Century: A Contrast Between European and English Speaking Countries, Oxford: Oxford University Press.

Feldstein, Martin (1988) "Imputing Corporate Tax Liabilities to Individual Taxpayers", National Tax Journal, 41(1), March, 37-59.

Fullerton, Don and Rogers, Diane Lim. Who Bears the Lifetime Tax Burden? Washington, DC: Brookings Institution, 1993.

Kasten, Richard; Sammartino, Frank and Toder, Eric. "Trends in Federal Tax Progressivity, 1980-93," J. Slemrod, Tax Progressivity and Income Inequality. Cambridge: Cambridge University Press, 1994, pp. 9-50.

Kopczuk, Wojciech, Saez, Emmanuel, and Jae Song (2006) "Income Mobility in the United States, 1937-2004: Evidence from Social Security Earnings Records", Working Paper.

Liebman, Jeffrey, "Redistribution in the Current U.S. Social Security System" in Martin Feldstein and Jeffrey B. Liebman, editors, The Distributional Aspects of Social Security and Social Security Reform (Chicago: University of Chicago Press), 2002.

Lindert, Peter (2004), Growing Public: Social Spending and Economic Growth since the $18^{\text {th }}$ Century, Cambridge University Press 
Parisi, Michael (2004-05) "Individual Income Tax Rates and Shares, 2002", Statistics of Income Bulletin, Winter, 20-58.

Pechman, J. Who Paid the Taxes: 1966-85? Washington DC: Brookings, 1985.

Pechman, Joseph A. and Okner, Benjamin A. Who Bears the Tax Burden? Washington, DC: Brookings Institution, 1974.

Piketty, Thomas (2003), "Income Inequality in France, 1901-1998", Journal of Political Economy, 111(5), 1004-1042.

Piketty Thomas, and Emmanuel Saez (2003), "Income Inequality in the United States, 1913-1998", Quarterly Journal of Economics, 118(1), 1-39.

Poterba, James and Scott Weisbenner (2001) "The Distributional Burden of Taxing Estates and Unrealized Capital Gains at Death," Rethinking Estate and Gift Taxation, edited by William G. Gale, James R. Hines, and Joel Slemrod, Brookings Institution, 422-449.

Saez, Emmanuel (2004), "Reported Incomes and Marginal Tax Rates, 19602000: Evidence and Policy Implications" in Ed. J. Poterba Tax Policy and the Economy 18, Cambridge: the MIT Press.

Strudler, Michael, Petska Tom, and Ryan Petska, "Further Analysis of the Distribution of Income and Taxes, 1979-2003." October 2005, Internal Revenue Service Working Paper. 
Table 1. Income and Federal Tax Rate Statistics in 2004 (based on 2000 inflated incomes)

\begin{tabular}{|c|c|c|c|c|c|c|c|c|}
\hline \multirow[b]{2}{*}{$\begin{array}{c}\text { Income Groups } \\
\text { (1) }\end{array}$} & \multirow[b]{2}{*}{$\begin{array}{c}\text { Average } \\
\text { Income } \\
\text { (pre-tax) } \\
(2)\end{array}$} & \multicolumn{5}{|c|}{ Average tax rates (percent) } & \multicolumn{2}{|c|}{ Income shares } \\
\hline & & $\begin{array}{c}\text { Federal } \\
\text { Individual } \\
(3)\end{array}$ & $\begin{array}{c}\text { Payroll } \\
\text { (Social } \\
\text { security+ } \\
\text { medicare) } \\
\text { Tax } \\
(4)\end{array}$ & $\begin{array}{c}\text { Federal } \\
\text { Corporate } \\
\text { (5) }\end{array}$ & $\begin{array}{c}\text { Federal } \\
\text { Estate } \\
\text { and Gift } \\
(6)\end{array}$ & $\begin{array}{c}\text { Total } \\
\text { Federal } \\
\text { Taxes } \\
(7)\end{array}$ & $\begin{array}{c}\text { Pre-tax } \\
\text { income } \\
\text { share } \\
(8)\end{array}$ & $\begin{array}{c}\text { Post-tax } \\
\text { income } \\
\text { share } \\
(9)\end{array}$ \\
\hline $\begin{array}{c}\text { Full Population } \\
\text { (144 million families) }\end{array}$ & $\$ 52,110$ & 11.5 & 9.3 & 2.3 & 0.4 & 23.4 & 100.0 & 100.0 \\
\hline P20-40 & $\$ 15,897$ & -3.2 & 10.6 & 2.0 & 0.0 & 9.4 & 6.1 & 7.2 \\
\hline$P 40-60$ & $\$ 29,870$ & 3.2 & 11.2 & 1.7 & 0.0 & 16.1 & 11.5 & 12.6 \\
\hline P60-80 & $\$ 52,137$ & 7.3 & 11.6 & 1.6 & 0.0 & 20.5 & 20.0 & 20.8 \\
\hline P80-90 & $\$ 83,012$ & 9.2 & 11.9 & 1.6 & 0.0 & 22.7 & 15.9 & 16.1 \\
\hline P90-95 & $\$ 117,709$ & 11.6 & 11.5 & 1.8 & 0.0 & 24.9 & 11.3 & 11.1 \\
\hline P95-99 & $\$ 199,033$ & 16.4 & 8.1 & 2.5 & 0.1 & 27.2 & 15.3 & 14.5 \\
\hline P99-99.5 & $\$ 428,690$ & 21.4 & 4.6 & 3.7 & 1.6 & 31.3 & 4.1 & 3.7 \\
\hline P99.5-99.9 & $\$ 863,607$ & 23.8 & 3.0 & 4.3 & 1.9 & 33.0 & 6.6 & 5.8 \\
\hline P99.9-99.99 & $\$ 3,158,720$ & 25.1 & 1.6 & 4.9 & 2.4 & 34.1 & 5.5 & 4.7 \\
\hline P99.99-100 & $\$ 18,113,612$ & 26.2 & 1.4 & 4.6 & 2.5 & 34.7 & 3.5 & 3.0 \\
\hline
\end{tabular}

Notes: Computations are based on income tax return statistics and NBER TAXSIM calculator.

They are based on incomes from 2000 adjusted for growth and using 2004 tax law.

Families are ranked based on market income excluding realized capital gains and imputed payroll and corporate taxes.

P20-40 denotes families between percentile 20th and percentile 40th of the income distribution (second quintile), etc.

Average income includes realized capital gains and imputed payroll and corporate taxes. Tax rates are estimated

relative to income including realized capital gains and imputed payroll and corporate taxes.

Payroll tax includes employee+employer Social Security and Medicare taxes (excludes payroll taxes for unemployment

and workers compensation) 
Table 2. Federal Tax Rates by Income Groups from 1960 to 2004

\begin{tabular}{ccccccc}
\hline & \multicolumn{7}{c}{ Average federal tax rates (percent) } \\
\cline { 2 - 7 } Income Groups & $\mathbf{1 9 6 0}$ & $\mathbf{1 9 7 0}$ & $\mathbf{1 9 8 0}$ & $\mathbf{1 9 9 0}$ & $\mathbf{2 0 0 0}$ & $\mathbf{2 0 0 4}$ \\
$(1)$ & $(2)$ & $(3)$ & $(4)$ & $(5)$ & $(6)$ & $(7)$ \\
\hline Full Population & 21.4 & 23.3 & 26.6 & 25.8 & 27.4 & 23.4 \\
P20-40 & 13.9 & 18.5 & 16.3 & 16.2 & 13.1 & 9.4 \\
P40-60 & 15.9 & 20.2 & 21.4 & 21.0 & 20.0 & 16.1 \\
P60-80 & 16.7 & 20.7 & 24.5 & 24.3 & 23.9 & 20.5 \\
P80-90 & 17.4 & 20.5 & 26.7 & 26.2 & 26.4 & 22.7 \\
P90-95 & 18.7 & 21.4 & 27.9 & 27.9 & 28.7 & 24.9 \\
P95-99 & 23.5 & 25.6 & 31.0 & 28.6 & 31.1 & 27.2 \\
P99-99.5 & 34.0 & 36.1 & 37.6 & 31.5 & 35.7 & 31.3 \\
P99.5-99.9 & 41.4 & 44.6 & 43.0 & 33.0 & 38.4 & 33.0 \\
P99.9-99.99 & 55.3 & 59.1 & 51.0 & 34.3 & 40.2 & 34.1 \\
P99.99-100 & 71.4 & 74.6 & 59.3 & 35.4 & 40.8 & 34.7 \\
\hline
\end{tabular}

The Table displays the average federal tax rate (including individual, corporate, payroll, and estate) for various groups of the income distribution, for various years.

2004 figures are based on 2004 tax law applied to 2000 incomes adjusted for economic growth. 
Table 3. International and Historical Comparison of Tax Rates

\begin{tabular}{|c|c|c|c|c|c|c|c|c|c|c|c|c|c|c|}
\hline \multirow[b]{3}{*}{$\begin{array}{l}\text { Income } \\
\text { Groups }\end{array}$} & \multicolumn{7}{|c|}{1970 (US, France, and UK) } & \multicolumn{7}{|c|}{2004 (US), 2005 (France), 2000 (UK) } \\
\hline & \multicolumn{5}{|c|}{ Average tax rates (percent) } & \multicolumn{2}{|c|}{ Shares (percent) } & \multicolumn{5}{|c|}{ Average tax rates (percent) } & \multicolumn{2}{|c|}{ Shares (percent) } \\
\hline & $\begin{array}{l}\text { Individua } \\
\text { I Income } \\
\text { Tax }\end{array}$ & $\begin{array}{l}\text { Payroll } \\
\text { Taxes }\end{array}$ & $\begin{array}{c}\text { Estate, } \\
\text { Gift, and } \\
\text { Wealth } \\
\text { Tax }\end{array}$ & $\begin{array}{l}\text { Corporat } \\
\text { e Tax } \\
\text { (US only) }\end{array}$ & $\begin{array}{l}\text { Total } \\
\text { Taxes }\end{array}$ & $\begin{array}{c}\text { Pre-tax } \\
\text { income } \\
\text { share }\end{array}$ & $\begin{array}{c}\text { Post-tax } \\
\text { income } \\
\text { share }\end{array}$ & $\begin{array}{c}\text { Individua } \\
\text { I Income } \\
\text { Tax }\end{array}$ & $\begin{array}{c}\text { Payroll } \\
\text { Taxes }\end{array}$ & $\begin{array}{l}\text { Estate, } \\
\text { Gift, and } \\
\text { Wealth } \\
\text { Tax }\end{array}$ & $\begin{array}{l}\text { Corporat } \\
\text { e Tax } \\
\text { (US only) }\end{array}$ & $\begin{array}{l}\text { Total } \\
\text { Taxes }\end{array}$ & $\begin{array}{c}\text { Pre-tax } \\
\text { income } \\
\text { share }\end{array}$ & $\begin{array}{c}\text { Post-tax } \\
\text { income } \\
\text { share }\end{array}$ \\
\hline \multicolumn{15}{|l|}{ A. United States } \\
\hline Full Population & 12.5 & 5.8 & 0.7 & 4.3 & 23.3 & 100.00 & 100.00 & 11.5 & 9.3 & 0.4 & 2.3 & 23.4 & 100.00 & 100.00 \\
\hline P0-90 & 9.9 & 7.2 & 0.0 & 3.2 & 20.2 & 67.61 & 70.54 & 5.4 & 11.5 & 0.0 & 1.5 & 18.5 & 53.75 & 57.28 \\
\hline P90-95 & 13.7 & 4.5 & 0.0 & 3.2 & 21.4 & 10.76 & 11.03 & 11.6 & 11.5 & 0.0 & 1.8 & 24.9 & 11.29 & 11.07 \\
\hline P95-99 & 16.1 & 3.0 & 0.7 & 5.7 & 25.6 & 12.60 & 12.23 & 16.4 & 8.1 & 0.1 & 2.5 & 27.2 & 15.28 & 14.51 \\
\hline P99-99.5 & 20.7 & 1.5 & 3.8 & 10.0 & 36.1 & 2.87 & 2.39 & 21.4 & 4.6 & 1.6 & 3.7 & 31.3 & 4.11 & 3.69 \\
\hline P99.5-99.9 & 25.8 & 0.9 & 5.8 & 12.0 & 44.6 & 3.63 & 2.62 & 23.8 & 3.0 & 1.9 & 4.3 & 33.0 & 6.63 & 5.80 \\
\hline P99.9-99.99 & 31.5 & 0.4 & 12.5 & 14.7 & 59.1 & 1.76 & 0.94 & 25.1 & 1.6 & 2.4 & 4.9 & 34.1 & 5.46 & 4.69 \\
\hline P99.99-100 & 32.2 & 0.1 & 23.4 & 19.0 & 74.6 & 0.76 & 0.25 & 26.2 & 1.4 & 2.5 & 4.6 & 34.7 & 3.48 & 2.96 \\
\hline \multicolumn{15}{|l|}{ B. France } \\
\hline Full Population & 5.3 & 20.8 & 0.3 & & 26.4 & 100.00 & 100.00 & 3.8 & 33.3 & 0.7 & & 37.8 & 100.00 & 100.00 \\
\hline P0-90 & 2.3 & 24.0 & 0.0 & & 26.3 & 69.30 & 69.39 & 1.8 & 34.8 & 0.1 & & 36.7 & 68.93 & 70.19 \\
\hline P90-95 & 6.4 & 17.6 & 0.2 & & 24.2 & 10.65 & 10.97 & 4.5 & 33.7 & 0.6 & & 38.8 & 11.57 & 11.39 \\
\hline P95-99 & 10.6 & 14.1 & 0.4 & & 25.1 & 12.51 & 12.74 & 7.0 & 31.4 & 1.4 & & 39.8 & 12.84 & 12.44 \\
\hline P99-99.5 & 16.8 & 10.6 & 0.8 & & 28.2 & 2.59 & 2.52 & 11.6 & 26.5 & 2.2 & & 40.3 & 2.36 & 2.27 \\
\hline P99.5-99.9 & 21.9 & 7.4 & 1.9 & & 31.2 & 3.09 & 2.88 & 16.4 & 21.4 & 5.1 & & 43.0 & 2.67 & 2.45 \\
\hline P99.9-99.99 & 30.2 & 4.2 & 4.2 & & 38.6 & 1.37 & 1.14 & 22.3 & 16.5 & 8.9 & & 47.8 & 1.19 & 1.00 \\
\hline P99.99-100 & 40.1 & 1.7 & 6.9 & & 48.8 & 0.50 & 0.35 & 28.8 & 8.5 & 24.2 & & 61.5 & 0.43 & 0.26 \\
\hline \multicolumn{15}{|c|}{ C. United Kingdom } \\
\hline Full Population & 17.1 & 7.0 & 1.1 & & 25.1 & 100.00 & 100.00 & 15.0 & 8.3 & 0.3 & & 23.7 & 100.00 & 100.00 \\
\hline P0-90 & 13.0 & 8.1 & 0.0 & & 21.2 & 71.64 & 75.42 & 9.7 & 7.6 & 0.0 & & 17.3 & 61.22 & 66.34 \\
\hline P90-95 & 19.0 & 5.8 & 0.2 & & 25.0 & 10.10 & 10.12 & 15.8 & 13.8 & 0.0 & & 29.6 & 11.72 & 10.81 \\
\hline P95-99 & 25.0 & 4.1 & 2.1 & & 31.2 & 11.41 & 10.49 & 21.7 & 11.9 & 1.0 & & 34.6 & 14.79 & 12.66 \\
\hline P99-99.5 & 32.3 & 2.4 & 5.5 & & 40.3 & 2.40 & 1.91 & 27.4 & 10.1 & 1.3 & & 38.8 & 3.45 & 2.76 \\
\hline P99.5-99.9 & 41.3 & 1.6 & 10.4 & & 53.4 & 2.86 & 1.78 & 30.5 & 8.6 & 1.3 & & 40.5 & 4.81 & 3.76 \\
\hline P99.9-99.95 & 52.3 & 1.0 & 16.5 & & 69.8 & 0.57 & 0.23 & 33.2 & 7.6 & 1.4 & & 42.2 & 1.30 & 0.98 \\
\hline P99.95-100 & 69.2 & 0.6 & 21.9 & & 91.7 & 1.01 & 0.11 & 34.5 & 6.5 & 1.5 & & 42.5 & 3.42 & 2.58 \\
\hline
\end{tabular}

Notes: Computations based on income tax return statistics. United Kingdom computations based on Atkinson (2006).

See Piketty and Saez (2006) for complete details on methodology.

Note that top group in the United Kingdom is P99.95-100 (and not P99.99-100 as in the US or France)

US numbers are based on 2004 tax law applied to 2000 incomes (adjusted to economic growth).

France numbers are based on 2005 tax law applied to 1998 incomes (adjusted to economic growth).

UK numbers are based on 2000 tax law applied to 2000 incomes (adjusted to economic growth).

UK and French computations exclude the corporate income tax. 


\section{A. Tax rates in 2004}

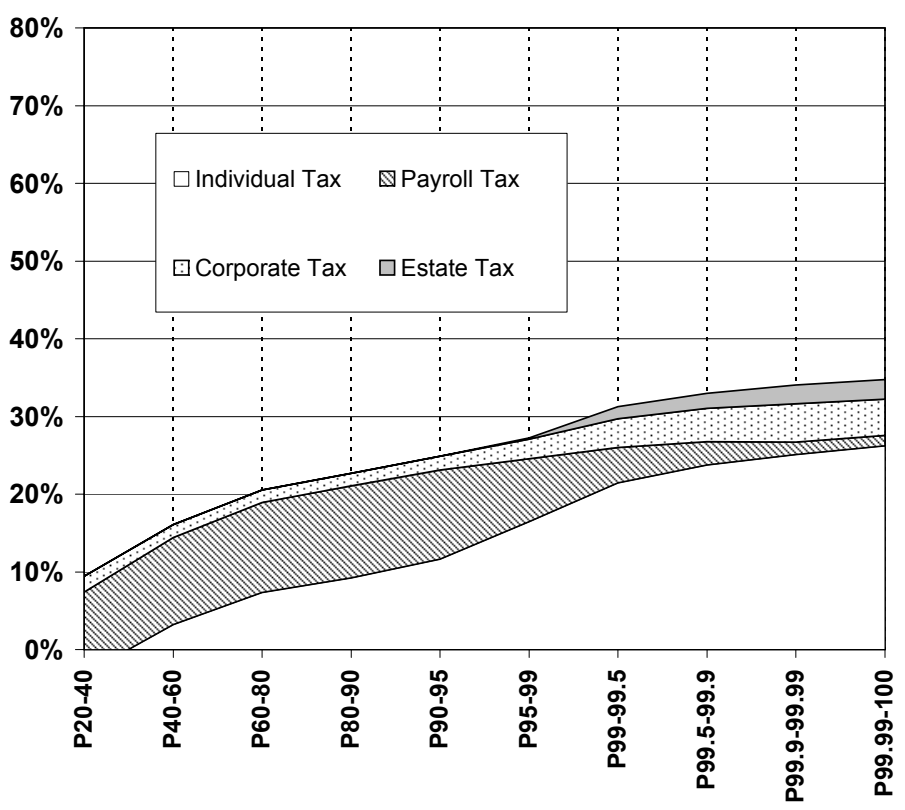

B. Tax rates in 1960

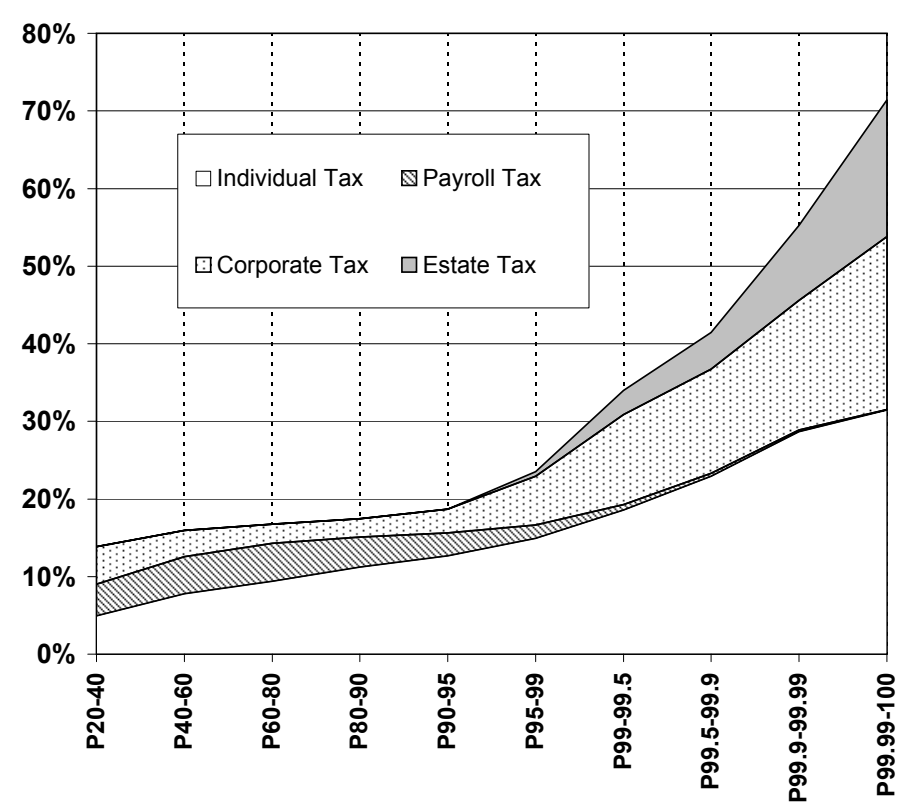

FIGURE 1

Federal Tax Rates in the United States in 2004 and 1960

Figures display the tax rate for each of the 4 federal taxes for various groups of the income distribution

in 2004 (based on 2000 incomes adjusted for economic growth) and in 1960. 


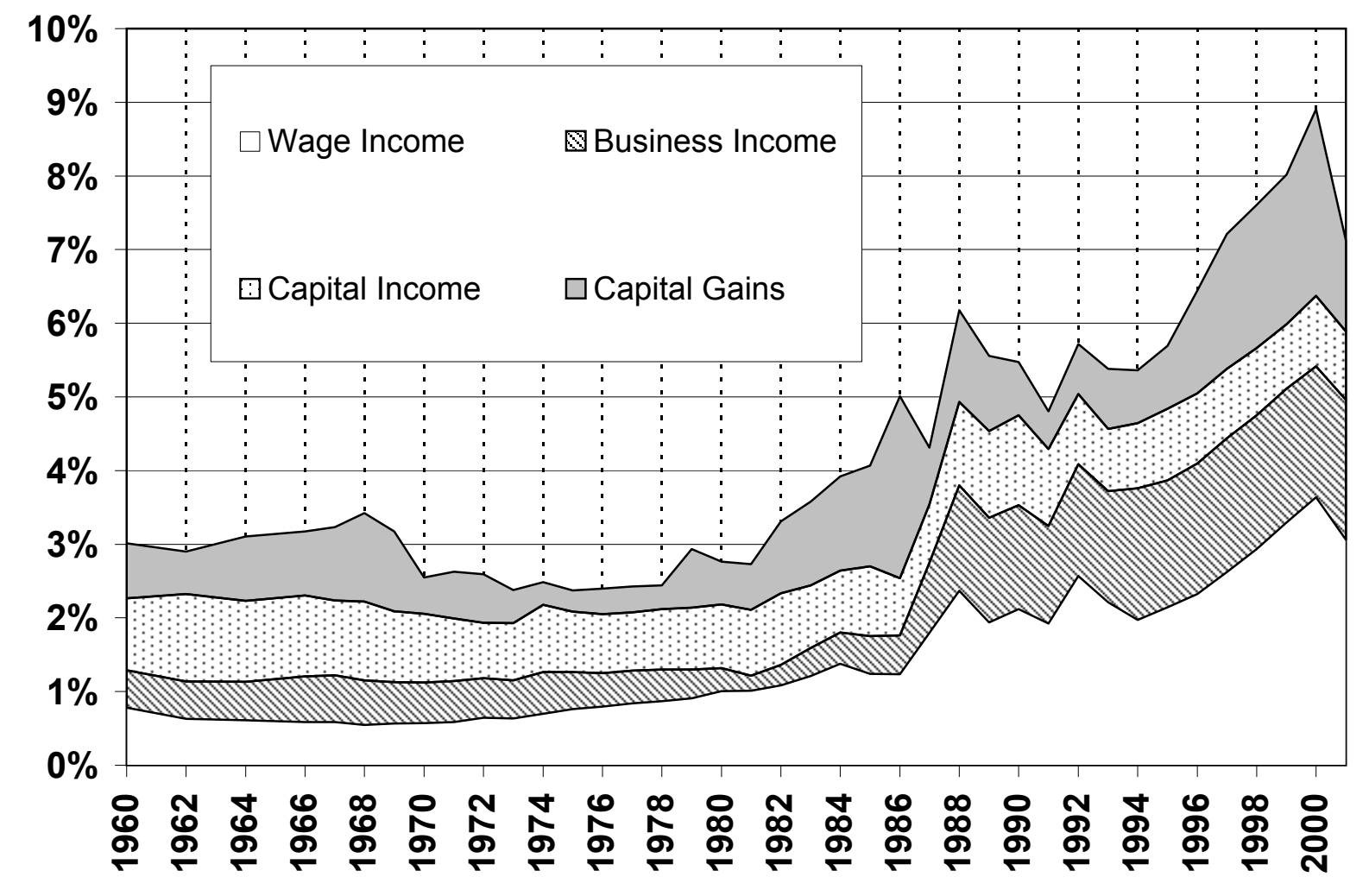

FIGURE 2

The Top 0.1\% Income Share and Composition, 1960-2001

The figure displays the income share of the top $0.1 \%$ tax units, and how the top $0.1 \%$ incomes are divided into four income components: wages and salaries (including exercised stock options), business income (S-corporation profits, partnership profits, sole proprietorship profits), capital income (di interest and rents), realized capital gains. Imputed corporate taxes are included in the corresponding cat Top $0.1 \%$ is defined based on individual market income excluding realized capital gains and corporate te 
A. Top $0.1 \%$ income share, before and after tax

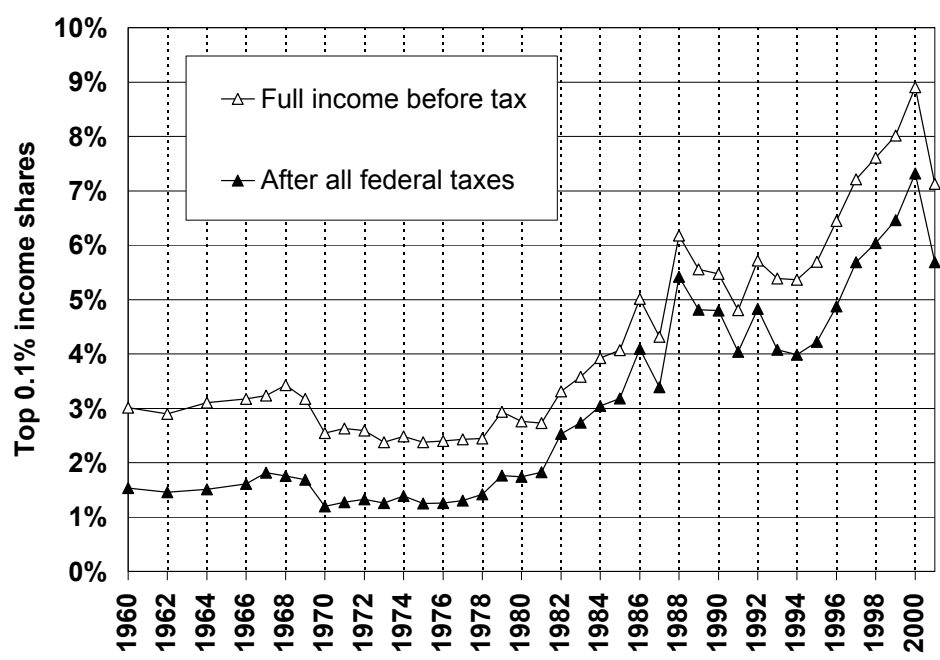

B. Top $0.1 \%$ average tax rate and share of taxes paid

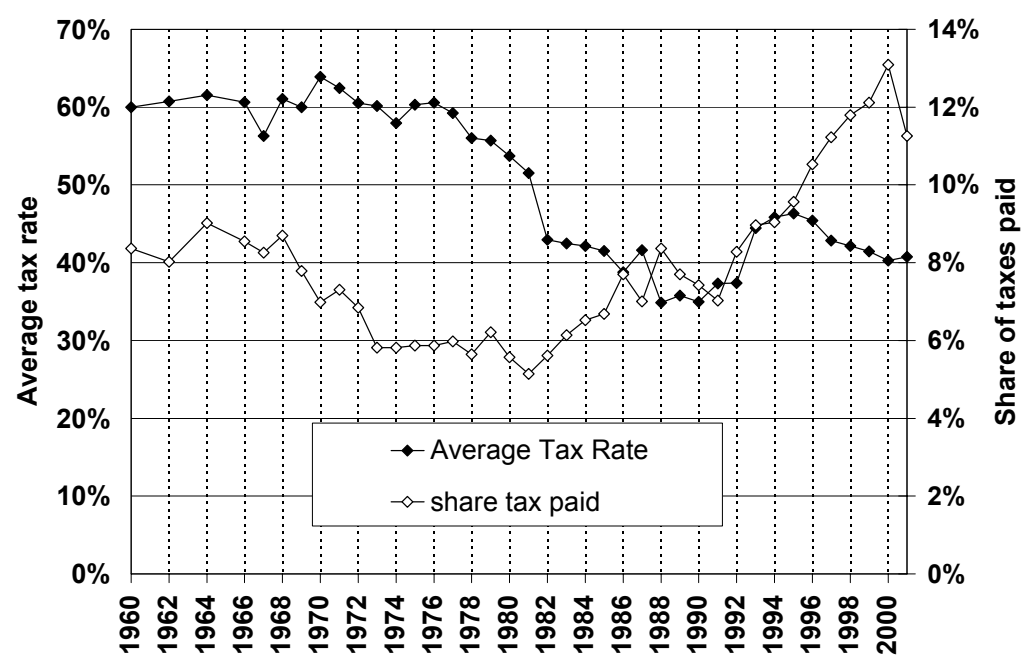

FIGURE 3

Top $0.1 \%$ income shares before and after tax, average tax rate, and share of taxes paid 


\section{A. Tax rates in 1970}

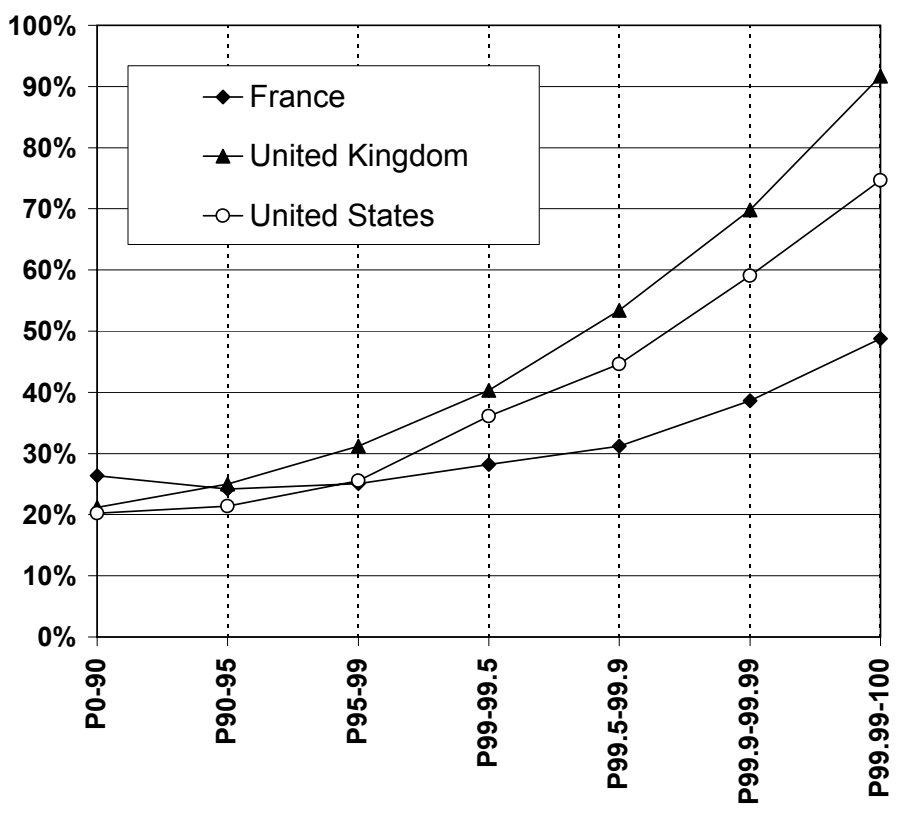

\section{B. Tax rates today}

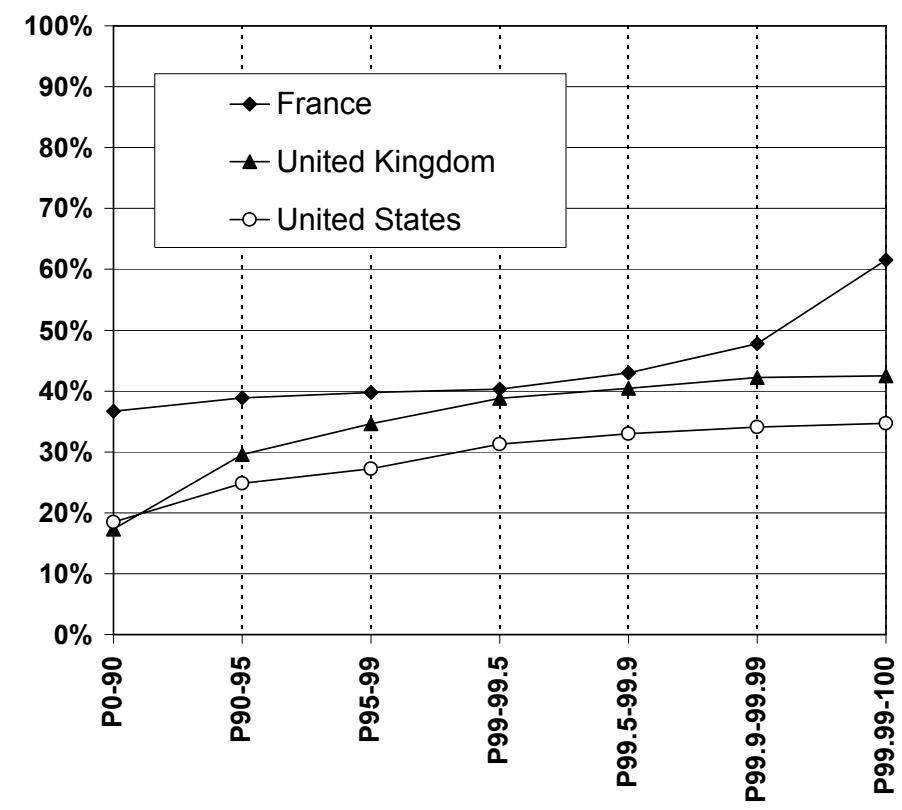

FIGURE 4

Tax Rates in France, the United Kingdom, and the United States in 1970 and today

Figure displays tax rates across income groups in the three countries.

Note that tax rates in the US include the 4 federal income taxes.

Tax rates in France and the United Kingdom include individual income taxes, payroll taxes, and estate and wealth taxes

but exclude corporate income taxes.

In the United Kingdom, the two top groups are P99.9-99.95 and P99.95-100 (instead of P99.9-99.99 and P99.99-100) 


\section{Appendix A: Sources and Methodology for Income and Tax Rates Statistics for the United States 1960-2004}

\section{A.1 Data and Methodology}

We use the publicly available individual tax return micro data constructed by the IRS. The data are repeated cross sections available quasi-annually from 1960 to 2001 . $^{1}$ The data oversample high income tax returns and allow a very detailed analysis of the top of the income distribution.

First, we rank tax returns based on a measure of gross income, which includes the sum of all market income components reported on tax returns but excluding realized capital gains. Those components include wages and salaries, employer and private pensions, small business income (sole proprietorships, partnerships, subchapter S corporations), taxable interest income, dividends, net rents, and other smaller items such as royalties or fiduciary income reported on tax returns. Our measure of income is consistent over the years and is essentially defined as Adjusted Gross Income (AGI) for tax purposes less realized capital gains included in AGI, less government transfers included in AGI such as Unemployment Insurance or Social Security Benefits, plus all the small adjustments which are made to gross income obtain AGI (such as moving expenses, self-employment taxes, etc.).

Second, we define groups such as quintiles, top decile, top percentile, etc. based on all tax units in the United States had everybody been required to file a tax return. This total number of tax units is taken from Piketty and Saez (2003) and was estimated from census data as the sum of all single adults (aged 20 and above) plus all married couples. From 1960 to 2001 , about $90 \%$ of tax units did file a tax return. We assume that non-filing tax units earn $20 \%$ of the average income of filing units. Non-filers tend to be retirees with social security transfer income and very small market incomes.

Third, we compute income earned by each group as the market income used for ranking tax units plus realized capital gains reported on tax returns plus the employer

\footnotetext{
${ }^{1}$ All years except 1961, 1963, and 1965 are available.
} 
part of federal payroll taxes (which is not included in wages and salaries reported on tax returns) plus imputed corporate taxes (see below for the imputation method). The shares of income accruing to each group are obtained by dividing the income of the group by total income from all groups (assuming again that non-filing units earn $20 \%$ of the average income of filing units).

Fourth, we compute taxes at the individual level in the micro-data as follows:

Individual federal income tax is computed using the TAXSIM calculator developed at the NBER. When doing those calculations, we do not deduct state income tax liabilities for federal tax purposes. As a result, our federal tax liability is slightly larger than the actual federal tax liability but gives a more accurate picture of federal tax progressivity as we are ignoring state taxes in this analysis.

Payroll taxes are computed based on the simple rate formulas. We include both the employee and the employer component of federal payroll taxes, which finance the Social Security and Disability benefits as well as Medicare benefits. For example, in 2004 , those taxes are equal to 15.3 percent of wages and salaries up to the $\$ 90,000$ cap and $2.9 \%$ of wages and salaries above the $\$ 90,000$ cap. The tax return data do not provide the breakdown of wages salaries at the individual level but payroll taxes are based on individual wages and salaries. As a result, we assume that wages and salaries for married tax filers are taxed up to $120 \%$ of the individual cap.

Corporate taxes are assumed to fall on all capital income earned by financial assets in the U.S. economy. ${ }^{2}$ We first compute total capital income earned by individuals as the sum of all capital income reported on tax returns (defined as realized capital gains, interest, dividends, rents and royalties, fiduciary income, and two thirds of profits from small businesses) and capital income earned by pension and insurance funds. The amount of capital income earned by pension and insurance funds is computed so that the ratio of capital income from those funds to capital income reported on individual returns is the same as the ratio of pension and insurance fund assets to other financial assets held by individuals (from the flow of funds accounts).

\footnotetext{
${ }^{2}$ We do not assume that corporate taxes fall on returns to real estate assets because we ignore imputed rents of home owners in this study.
} 
We then compute an effective corporate tax rate defined as federal corporate tax liabilities (accruing in the current calendar year and reported in the National Income Accounts) divided by total capital income estimated as above.

This corporate rate is applied to capital income reported on tax returns (defined as above). This corporate rate is also applied to estimated capital income form pension and insurance funds. We then assume that this part of the corporate tax falls proportionately on wages and salaries and pensions (as the vast majority of returns from pension funds accrues to current employees and retired employees).

Total federal estate and gift taxes are taken from National Income Accounts. We assume that estate and gift taxes fall on decedents. We assume that the top $1 \%$ decedents are in the top $1 \%$ income group, etc. We define the top $1 \%$ decedents as one percent of all adult decedents (aged 20 and above) in the United States. Then, using the distribution tables produced by the IRS for estate tax, we estimate the fraction of estate taxes paid by the top $1 \%$ decedents. We then assume that the top $1 \%$ income earners bear the same fraction of all estate and gifts taxes estimated in the National Income Accounts.

Once the four federal taxes are computed for each group, we divide taxes paid by income earned for each group to obtain the corresponding tax rates. The total federal tax rate is the sum of all four taxes.

Table A0 displays the total number of tax units, the number of tax returns actually filed, and the nominal average income per tax unit.

Tables A1 and A2 display the pre-tax and post-tax (respectively) income shares for the various income groups we consider.

Table A3 reports the tax rates for each of the four taxes we consider (individual, payroll, corporate, and estate) as we as the total tax rate for all the income groups we consider.

\section{A.2 Comparison with US government agencies estimates}


Government agencies such as the Internal Revenue Service (IRS) and the Congressional Budget Office (CBO) produce annual statistics on tax progressivity in the United States. Our approach differs from the IRS statistics (Parisi, 2004-05; Strudler et al., 2005), because those IRS statistics ignore other federal taxes such as the corporate income tax, the estate tax, or payroll taxes.

CBO (2001) has also produced federal tax estimates by income groups for the period 1979-2001 (updated to 2004). The department of Treasury and the Joint Committee on Taxation also produce distributional analyses to evaluate tax reforms. Their distributional analyses are close to those of CBO (see CBO, 2001). Those two agencies do not produce systematic annual estimations as the CBO does but rather produce distributional calculations for any tax reform that is proposed by the Treasury department or Congress. As a result, we will focus on the comparison with $\mathrm{CBO}$ estimates. CBO estimates differ from the current estimates for a number of reasons (see Chapter 2 in CBO (2001) for a detailed methodological description). By order of importance:

First, CBO focuses primarily on quintiles and breaks down the top quintile in the top decile, and top percentile but does not study smaller groups within the top percentile. Hence while our analysis is primarily focused on progressivity within the top decile and especially the top percentile, CBO focuses more on overall progressivity.

Second and related, CBO does not include estate taxes in its estimates which is not very important below the top percentile but would substantially change our findings within top groups. In contrast to our study, CBO does include federal excise taxes (mostly taxes on tobacco, alcohol and gasoline) which are relatively small and negligible at the top.

Third, CBO estimates are based on a more comprehensive definition of income that the one we use. CBO definition also includes the imputed cash value of employer provided benefits (such as health insurance), voluntary retirement contributions (such as $401(\mathrm{k}) \mathrm{s}$ ), ${ }^{3}$ and all transfer programs from the government

\footnotetext{
${ }^{3} \mathrm{CBO}$ (2001) acknowledges that counting both workers contributions to retirement plans and pension withdrawals of retirees is double counting. Therefore, it seems more rational to us to count only income when the tax is due (typically at retirement for most US retirement programs).
} 
(cash welfare but also in-kind programs such as Medicaid, and Medicare, food stamps). Our view is that an AGI based measure of income is much more familiar to readers than a more comprehensive measure including in-kind employer benefits. More importantly, we believe that government transfers should be conceptually considered as part of the tax and transfer system as they are two tools that the government uses simultaneously for redistribution. Hence we think that it is preferable to ignore transfers entirely (and focus on top groups where they are not important) as we do here rather than count them in income and offer a partial and somewhat arbitrary view of government redistribution as the $\mathrm{CBO}$ does.

Furthermore, in the CBO study, income groups are determined based on full income including realized gains. This latter assumption reduces significantly individual income tax rates at the top in the period 1979-1986 when realized capital gains were treated very favourably (only $40 \%$ of gains were included in taxable income). As discussed in the main text, realized capital gains are a very volatile and lumpy source of income so that we believe that it is more meaningful to rank tax units based on income excluding realized capital gains and then add back those gains to our income measures. ${ }^{4}$ This is an especially important issue for top groups.

Fourth, CBO focuses on households instead of tax units. A household is defined as the set of individuals living together and may contain several tax units (for example, two single adult sisters living together). There are about 144 million tax units in the United States in 2004 (had everybody been required to file a tax returns) but there are only about 110 million households. In order to rank household into income groups, CBO adjusts household income by the number of individuals in the household by dividing household income by the square root of the number of individuals. For example, a family of four earning $\$ 100,000$ will be assigned income $\$ 50,000=100,000 /$ sqrt(4) in the ranking. Income groups such as quintiles are chosen to contain the same number of individuals (but not of households). Those complex adjustments are made to try and measure better real disposable income at the individual level. However, they come at a cost in complexity: groups are no longer transparently defined groups by thresholds based on a familiar AGI type measure of income.

\footnotetext{
${ }^{4} \mathrm{CBO}$ is aware of this issue and mentions that the ideal solution is to make a life-time based analysis of income and taxes. We agree with $\mathrm{CBO}$ but still believe that our ranking excluding capital gains is an acceptable short-cut which parsimoniously removes the largest issue with fluctuating incomes.
} 
Finally, $\mathrm{CBO}$ imputes corporate taxes only on reported capital income while we impute corporate taxes on all capital income either reported as capital income on tax returns or accruing to non-taxable pension funds (which we impute on wage income). Because of the large development of pension funds since 1980, corporate taxes fall relatively more on labor income today than in previous decades. This factor contributes to reducing the progressivity of corporate taxes.

Figure $A 3$ and $A 4$ report the average tax rates for the top 1\% from our estimates and from CBO respectively. Those series overlap for years 1979 to 2001. The broad patterns are comparable. We see that the CBO estimates are slightly lower because of their more comprehensive income definition. CBO also finds a lower decline in individual tax rates in the 1980s primarily because they include realized capital gains in the ranking of tax units. As a result, their tax rates are relatively higher in the pre-1987 period when capital gains received a very favourable treatment (only $40 \%$ of such gains were included in taxable income).

\section{Appendix B : Sources and Methodology for Income and Tax Rates Statistics for France and the United Kingdom 1970 and today}

Table A4 reports various aggregate income and tax statistics for the United States, the United Kingdom, and France in 1970 and today (2004 for the US, 2000 for the UK, and 2005 for France). Panel A reports aggregate statistics: total personal income, total number of tax units, average real pre and post tax income per tax unit, as well as average tax rate for each of the taxes we consider. Panel B reports average tax rates from OECD (2005) for all taxes. Those rates are computed as the ratio of the nominal amounts reported in OECD (2005) divided by the total income used in this study (reported in Panel A). US tax rates reported by OECD include not only federal but also state and local taxes, explaining the discrepancy. The main discrepancies between the French and UK tax rates used in the study and the OECD rates are explained below.

\section{B.1 France}


Income levels: net-of-payroll-tax income levels for fractiles P0-90, P90-95,..,P99.99100 are borrowed from Piketty (2001, Appendix B). ${ }^{5}$ These were computed using published tax tabulations annualy available since 1914 and large tax returns micro files available since 1988. Income levels for 2005 were obtained by updating 1998 estimates (the latest year covered in Piketty (2001)), using 1998-2002 published tax tabulations and average household income growth rates for 2002-2005. In the same way as for the U.S., tax units were ranked based on income excluding realized capital gains, and realized capital gains were then added back to the average income of each fractile and incorporated into the capital income component. ${ }^{6}$ Finally, employer and employee payroll tax (both are deductible from income subject to the income tax in France) were added to the average income of each fractile and incorportated into the wage income component, using the methodology described below.

Individual Income tax rates: income tax rates for fractiles P0-90, P90-95,..,P99.99100 are borrowed from Piketty (2001, Appendix B). These were computed using published tax tabulations annually available since 1914 and large tax returns micro files available since 1988. Income levels for 2005 were obtained by updating 1998 estimates (the latest year covered in Piketty (2001)), using 1998-2005 changes in the income tax schedule (current tax schedules are available on www.impots.gouv.fr). Tax on the capital gains component (a flat tax of 15\%) was incorporated in the effective income tax rate of each fractile.

Payroll tax rates: payroll tax rates for fractiles P0-90, P90-95,..,P99,99-100 were computed using the detailed 1950-2005 payroll tax schedules published by INSEE. ${ }^{7}$ Payroll tax schedules are fairly complex in France, and we made the following simplifying assumptions. In France gross wages $w$ are subject to a total employee payroll tax rate $t_{1}$ and to a total employer payroll tax rate $t_{2}$. Total labor cost is equal to $\left(1+t_{2}\right) w$, and net-of-payroll-tax wage is equal to $\left(1-t_{1}\right) w$ (this is the wage income subject to the income tax). Therefore one needs to multiply income-tax wage income by $\left(1+t_{2}\right) /\left(1-t_{1}\right)$ in order to compute imputed payroll tax. This is roughly what we did

\footnotetext{
${ }^{5}$ A much shortened, English-language version of Piketty (2001) was published in Piketty (2003).

${ }^{6}$ We used both for 1970 and 2005 the average percentages in additional income corresponding to capital gains reported in Piketty (2001, Appendix B) for years 1988-1995 (percentages rank from $0.4 \%$ for fractile P0-90 to $5.0 \%$ for fractile P99-99.5 and $21.0 \%$ for fractile P99.99-100).

${ }^{7}$ See INSEE Résultats $n^{\circ} 735$, «Séries longues sur les salaires édition 200x » (various years).
} 
for each fractile P0-90, P90-95,..,P99.99-100 for years 1970 and 2005, using data on income composition by fractile (wage income share, capital income share, business income share) borrowed from Piketty (2001, Appendix B). In 2005, we used $\mathrm{t}_{1}=22.5 \%$ and $t_{2}=42.5 \%$. In 1970 , we used $t_{1}=8.2 \%$ and $t_{2}=32.8 \%$. For both years and for both employee and employer payroll tax, the pure-tax component of payroll taxes (i.e. those designed to pay for lump-sum benefits such as health insurance, worker training programmes, etc., and means-tested benefits such as family benefits) and the contributions-related component of payroll taxes (i.e. those designed to pay for pensions and unemployment insurance benefits). ${ }^{8}$ Most contributions-related benefits are roughly proportional to contributions (and hence to wages), with numerous exceptions and complications due to intergenerational redistribution effects, so that according to standard estimates around $50 \%$ of contributions-related payroll taxes can be viewed as a pure tax. For simplicity, in this study, we consider that entire payroll tax financing benefits in France as a pure tax. An additional complication comes from the fact that some payroll taxes are levied up to a wage ceiling and some are levied on all wages. The key parameter is the so-called "plafond de la Sécurité sociale" $P$. The level of $P$ is adjusted every year and is currently equal to about $29,000 €$ (gross annual wage), i.e. about twice the minimum wage. In 2005 , out of the $22.5 \%$ total employee payroll tax rate, $5.0 \%$ was levied on wages up to $4 \mathrm{P}, 8.8 \%$ on wages up to $8 \mathrm{P}$, and $8.7 \%$ on all wages (no ceiling). Out of the $42.5 \%$ total employer payroll tax rate, $7.5 \%$ was levied up to $4 \mathrm{P}$, and $35 \%$ on all wages. In 1970 , out of the $8.2 \%$ total employee payroll tax rate, $5.6 \%$ was levied on wages up to $1 \mathrm{P}, 1.6 \%$ on wages up to $4 \mathrm{P}$, and $1 \%$ on all wages (no ceiling). Out of the $32.8 \%$ total employer payroll tax rate, $19.3 \%$ was levied up to $1 \mathrm{P}, 9.9 \%$ on wages up to $4 \mathrm{P}$, and $3.6 \%$ on all wages. We applied to those rules to average wage income for each fractile P0-90, P90-95,..,P99.99-100 (assuming all tax units in each fractile receive the same average wage income). Note that although most benefits are nontaxable in France (and are therefore excluded from the income concept used for our computations), most pensions are taxable (with the exception of minimum pensions) and are incorporated in the wage income category of tax statistics. Pure wage income (excluding pension income) made up about $80 \%$ of total wage income in

\footnotetext{
${ }^{8}$ For simplicity and for the sake of comparability, we include CSG (Contribution Sociale Generalisee) in employee payroll tax in 2005. CSG is the proportional income tax on all incomes (not only wage income) which gradually replaced health-insurance employee payroll tax (and partly family-benefits employee payroll tax) since 1991.
} 
2005 and $90 \%$ in 1970 , so we applied payroll taxes to $80 \%$ and $90 \%$ of wage income (respectively). Finally, note that payroll tax rates applied to public-sector wages are significantly smaller than the rates applied to private-sector wages, especially because there is virtually no formal employer payroll tax in the public sector (in particular, public sector pensions are unfunded and are paid out of the general budget). However, income-tax-based income statistics do not offer any public/private wage decomposition, so we chose to apply private-sector payroll tax rates to all wage incomes. This largely explains why our estimated aggregate payroll tax rates $(33.3 \%$ of total income in $2005,20.8 \%$ in 1970) are somewhat larger than actual payroll income tax receipts (our estimates are about $5 \%$ larger than tax receipts for 1970 , and about 15\% larger in 2005). In a sense, our larger estimates are closer to the true economic payroll tax rates (unfunded public-sector benefits are paid for by general taxes such as the VAT). In 2005, our slight overestimate of payroll tax receipts is reinforced by the fact that we neglected the low-wage employer payroll tax cut schemes that were set up in France since the mid-1990s in order to boost low-skill labor demand. As of 2005 , the $42.5 \%$ employer payroll tax rate was reduced to $24.5 \%$ at the minimum wage level, and increased linearly up to the statutory $42.5 \%$ rate at the level of 1.6 minimum wages (the exemption corresponds to the healthinsurance and family-benefits components). However these low-wage payroll tax cut schemes change virtually every year, and they are difficult to properly take into account using income-tax-based income statistics (leaving alone the fact that they are mostly shifted on the employer side, due to high unemployment and the minimum wage constraint).

Estate tax rates: estate tax rates for fractiles P0-90, P90-95,..,P99.99-100 were computed using top estate fractiles borrowed from Piketty (2001, Appendix J). ${ }^{9}$ In the same way as for the United States, we computed estate tax rates using estate fractiles (estate fractiles were defined using the population of all adult decedents, including those with no wealth at death), and we then assume that those taxes are borne by the corresponding fractiles of income tax returns. Updated estate tax schedules for 2005 are available on www.impots.gouv.fr (they were virtually

\footnotetext{
${ }^{9}$ Estate tax tabulations and micro-files unfortunately do not exist on an annual basis in France (see Piketty (2001, Appendix J). For 2005, we updated the 1994 figures using the 1994-2005 income growth rate. For 1970, we updated the 1964 figures using the 1964-1970 income growth rate.
} 
unchanged since 1984, when the top marginal rate was raised from $20 \%$ to $40 \%$ ). Estate tax schedules for 1970 are given in Piketty (2001, Appendix J). In France, estate tax rates are vastly higher when estates are transmitted to indivuals outside the family (or even to brothers and sisters) than when they are transmitted to spouses and children (so-called "transmission en ligne directe", "direct line estate"). We used the "direct-line" estate tax schedules, but we then scaled up effective rates so as to match observed estate tax receipts for 1970 and 2005 (receipts are available in published estate tax tabulations).

Wealth tax rates: wealth tax ("impôt sur la fortune", ISF) rates for fractiles P0-90, P90-95,..,P99.99-100 were computed using top wealth fractiles borrowed from Piketty (2001b, statistical appendix). ${ }^{10}$ The wealth tax currently applied in France did not exist in 1970: it was created in 1981 following the election of the socialist government ("impôt sur les grandes fortunes", IGF), repealed in 1986, and reinstated again in 1989 ("impôt sur la fortune", ISF) to finance the minimum income scheme (RMI) introduced by the new socialist government. As of 2005 , the wealth tax applies to all tax units with total wealth above $750,000 €$ (about $1 \%$ of all tax units), and the top marginal rate (above 15.5 millions $€$ ) is $1.8 \%$ (see www.impots.gouv.fr for the full schedule). We applied the 2005 schedules to 2005 top wealth fractiles (fractiles were defined using the population of all tax units). Because we could not take into account all tax exemptions and tax loopholes, this leads to a slight overestimate of tax receipts, so we scaled down all rates to reproduce tax receipts. In the same way as for the estate tax, we then assumes that those taxes are borne by the corresponding fractiles of income tax returns.

Table A5 provides the real income levels for each group, along with the tax rates for each of the taxes estimated for France in 1970 and 2005.

\section{B.2 United Kingdom}

Income levels: net-of-payroll-tax income levels for fractiles P0-90, P90-95,...,P99,99100 are borrowed from Aktinson (2006). These were computed using published tax

\footnotetext{
${ }^{10}$ For 2005 , we updated the 2000 figures using the 1990-2000 annual average wealthgrowth rate.
} 
tabulations annually available and reported in Inland Revenue Statistics. Those estimates exclude realized capital gains. In contrast to the French and US case, the UK income estimates do not include realized capital gains. Finally, employer payroll taxes are added to the average income of each fractile and incorporated into the wage income component, using the methodology described below. It is important to note that, in contrast to the US and French cases, the top group for the UK in Atkinson (2006) series is P99.95-100 and not P99.99-100. As a result, we have also had to use P99.95-100 as our top group for the UK case.

Individual Income tax rates: income tax rates for fractiles P0-90, P90-95,..,P99.95100 are estimated from Atkinson (2006) who reports top income shares both pre-tax and post-tax. Tax rates are estimated as one minus the ratio of post tax shares to pre tax shares multiplied by the ratio of pre tax to post tax total income. It should be noted that post tax shares in Atkinson (2006) are estimated based on tax units ranked by post-tax income (instead of pre-tax income for France and the United States). This would tend to make UK income tax rates slightly lower than US and French tax rates. Because ranking of incomes pre and post tax must be very close, this effect is probably almost negligible. The individual income tax does not include the supplementary tax on realized capital gains.

\section{Payroll tax rates:}

In 1970, payroll tax financing social security on employees is $7 \%$ of earnings below a cap (close to average earnings) and the payroll tax financing social security on employers is $8 \%$ of earnings below the same cap. ${ }^{11}$ The cap applies to weekly earnings and the annual value of the cap is around 1,000 Pounds. In 2000, payroll tax on employees is $10 \%$ of earnings between 4,000 and 28,000 Pounds. The payroll tax on employer is $12.2 \%$ of earnings above 4,000 Pounds with no cap. The threshold and cap also apply at the weekly level which we have annualised. Payroll taxes in the UK finance primarily the Universal government provided health insurance system, and hence can be considered as a pure tax. We have used the decomposition of income into labor and capital income components reported in

\footnotetext{
${ }^{11}$ There was also an additiona small payroll tax on the workforce (which did not finance social security programs) which is excluded from the study but reported included the payroll tax statistics from OECD reported on Table A4 which explains the (small) discrepency between the total payroll tax rate used in the study and the OECD payroll tax rate. Exlcuding this tax has only very minor effects on top groups.
} 
Atkinson (2006) to estimate corresponding payroll tax rates using the same methodology as in the case of France.

Estate tax rates: estate tax rates for fractiles P0-90, P90-95,..,P99.95-100 were computed using estate tax statistics. In the same way as for the US and France, we computed estate tax rates using estate fractiles (estate fractiles were defined using the population of all decedents, including those with no wealth at death), and we then assumes that those taxes are borne by the corresponding fractiles of income tax returns. Estate tax statistics for the United Kingdom are published in Inland Revenue Statistics (various years). 


\section{Appendix Additional References}

Inland Revenue (various years), Inland Revenue Statistics, London: Her Majesty's Stationery Office.

OECD (2001), Revenue Statistics, 1965-2004, Paris: OECD Publishing.

Piketty, Thomas (2001a), Les hauts revenus en France au $20^{\mathrm{eme}}$ siecle - Inegalites et redistributions, 1901-1998, Paris : Editions Grasset (812p.)

Piketty, Thomas (2001b), "Les Inégalités dans le long terme », in Conseil d'analyse économique: Inégalités économiques, Paris : la Documentation française, 2001, pp.137-204. 
TABLE A0. Reference Totals for Tax Units and Income, 1960-2004

\begin{tabular}{|c|c|c|c|c|}
\hline & \multicolumn{3}{|c|}{ Tax Units and Population } & \multirow[b]{2}{*}{$\begin{array}{c}(8) \\
\text { Average income } \\
\text { (nominal \$) }\end{array}$} \\
\hline & $\begin{array}{c}\text { (1) } \\
\text { Tax Units } \\
\text { ('000s) }\end{array}$ & $\begin{array}{c}(2) \\
\text { Number of } \\
\text { tax returns } \\
\text { ('000s) }\end{array}$ & $\begin{array}{c}(3) \\
(2) /(1) \\
(\%)\end{array}$ & \\
\hline 1960 & 68,681 & 61,028 & 88.9 & 5,175 \\
\hline 1961 & 69,997 & 61,499 & 87.9 & \\
\hline 1962 & 71,254 & 62,712 & 88.0 & 5,472 \\
\hline 1963 & 72,464 & 63,943 & 88.2 & \\
\hline 1964 & 73,660 & 65,376 & 88.8 & 6,119 \\
\hline 1965 & 74,772 & 67,596 & 90.4 & \\
\hline 1966 & 75,831 & 70,160 & 92.5 & 7,018 \\
\hline 1967 & 76,856 & 71,652 & 93.2 & 7,440 \\
\hline 1968 & 77,826 & 73,729 & 94.7 & 8,122 \\
\hline 1969 & 78,793 & 75,834 & 96.2 & 8,559 \\
\hline 1970 & 79,924 & 74,280 & 92.9 & 8,838 \\
\hline 1971 & 81,849 & 74,576 & 91.1 & 9,302 \\
\hline 1972 & 83,670 & 77,573 & 92.7 & 10,089 \\
\hline 1973 & 85,442 & 80,693 & 94.4 & 10,954 \\
\hline 1974 & 87,228 & 83,340 & 95.5 & 11,688 \\
\hline 1975 & 89,127 & 82,229 & 92.3 & 12,015 \\
\hline 1976 & 91,048 & 84,670 & 93.0 & 13,153 \\
\hline 1977 & 93,076 & 86,635 & 93.1 & 14,170 \\
\hline 1978 & 95,213 & 89,771 & 94.3 & 15,562 \\
\hline 1979 & 97,457 & 92,694 & 95.1 & 17,202 \\
\hline 1980 & 99,625 & 93,902 & 94.3 & 18,412 \\
\hline 1981 & 101,432 & 95,396 & 94.0 & 19,891 \\
\hline 1982 & 103,250 & 95,337 & 92.3 & 20,526 \\
\hline 1983 & 105,067 & 96,321 & 91.7 & 21,563 \\
\hline 1984 & 106,871 & 99,439 & 93.0 & 23,298 \\
\hline 1985 & 108,736 & 101,660 & 93.5 & 24,666 \\
\hline 1986 & 110,684 & 103,045 & 93.1 & 26,433 \\
\hline 1987 & 112,640 & 106,996 & 95.0 & 26,817 \\
\hline 1988 & 114,656 & 109,708 & 95.7 & 29,194 \\
\hline 1989 & 116,759 & 112,136 & 96.0 & 30,222 \\
\hline 1990 & 120,447 & 113,717 & 94.4 & 30,756 \\
\hline 1991 & 120,453 & 114,730 & 95.2 & 31,199 \\
\hline 1992 & 121,944 & 113,605 & 93.2 & 32,357 \\
\hline 1993 & 123,378 & 114,602 & 92.9 & 32,987 \\
\hline 1994 & 124,716 & 115,943 & 93.0 & 34,345 \\
\hline 1995 & 126,023 & 118,218 & 93.8 & 36,401 \\
\hline 1996 & 127,798 & 120,351 & 94.2 & 38,660 \\
\hline 1997 & 129,532 & 122,422 & 94.5 & 41,539 \\
\hline 1998 & 131,720 & 124,771 & 94.7 & 44,204 \\
\hline 1999 & 133,233 & 127,075 & 95.4 & 47,133 \\
\hline 2000 & 134,473 & 129,374 & 96.2 & 50,122 \\
\hline 2001 & 137,088 & 130,255 & 95.0 & 47,968 \\
\hline 2002 & 139,703 & 130,076 & 93.1 & \\
\hline 2003 & 141,843 & 130,424 & 91.9 & \\
\hline 2004 & 143,982 & 132,385 & 91.9 & \\
\hline
\end{tabular}

Notes: Population and tax units estimates based on census and current population surveys.

Tax units estimated as sum of married men, divorced and widowed men and women, and singles men and women aged 20 and over. Income defined as market income reported on income tax returns plus employer federal payroll taxes and imputed corporate taxes.

Income includes all realized capital gains reported on tax returns.

Income of non-filers is imputed as $20 \%$ of average income. 
Table A1. Pre-tax Top Income Shares in the United States, 1960-2001

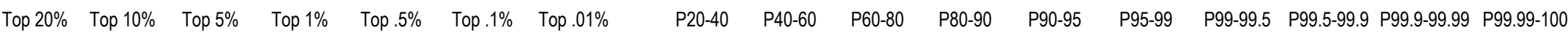

\begin{tabular}{|c|c|c|c|c|c|c|c|c|c|c|c|c|c|c|c|c|c|}
\hline 1960 & 49.27 & 33.09 & 22.69 & 10.07 & 7.02 & 3.01 & 0.93 & 7.58 & 15.59 & 23.84 & 16.19 & 10.42 & 12.63 & 3.06 & 4.01 & 2.08 & 0.93 \\
\hline 1962 & 50.25 & 33.60 & 22.86 & 10.00 & 6.92 & 2.90 & 0.87 & 7.39 & 15.55 & 24.18 & 16.65 & 10.73 & 12.81 & 3.05 & 3.97 & 2.01 & 0.86 \\
\hline 1964 & 50.84 & 34.23 & 23.52 & 10.44 & 7.27 & 3.10 & 0.97 & 7.29 & 15.32 & 24.26 & 16.61 & 10.70 & 13.06 & 3.16 & 4.14 & 2.12 & 0.97 \\
\hline 1966 & 50.35 & 33.88 & 23.35 & 10.43 & 7.26 & 3.17 & 1.00 & 7.59 & 15.47 & 24.23 & 16.47 & 10.52 & 12.90 & 3.16 & 4.06 & 2.16 & 0.99 \\
\hline 1967 & 50.80 & 34.37 & 23.77 & 10.71 & 7.50 & 3.23 & 0.97 & 7.66 & 15.41 & 23.97 & 16.42 & 10.60 & 13.06 & 3.20 & 4.26 & 2.26 & 0.96 \\
\hline 1968 & 51.16 & 34.75 & 24.19 & 11.13 & 7.87 & 3.43 & 1.02 & 7.81 & 15.36 & 23.90 & 16.41 & 10.57 & 13.05 & 3.26 & 4.44 & 2.40 & 1.01 \\
\hline 1969 & 50.46 & 33.77 & 23.15 & 10.31 & 7.25 & 3.18 & 1.02 & 8.11 & 15.78 & 24.48 & 16.69 & 10.62 & 12.82 & 3.06 & 4.06 & 2.15 & 1.01 \\
\hline 1970 & 49.29 & 32.47 & 21.71 & 9.09 & 6.20 & 2.55 & 0.77 & 8.06 & 15.73 & 24.48 & 16.82 & 10.76 & 12.60 & 2.87 & 3.63 & 1.76 & 0.76 \\
\hline 1971 & 49.93 & 32.93 & 22.06 & 9.24 & 6.33 & 2.63 & 0.79 & 7.63 & 15.39 & 24.49 & 17.00 & 10.87 & 12.80 & 2.90 & 3.69 & 1.83 & 0.78 \\
\hline 1972 & 49.79 & 32.83 & 21.95 & 9.19 & 6.26 & 2.59 & 0.80 & 8.02 & 15.43 & 24.48 & 16.96 & 10.88 & 12.75 & 2.92 & 3.66 & 1.79 & 0.79 \\
\hline 1973 & 49.73 & 32.72 & 21.82 & 8.82 & 5.94 & 2.38 & 0.67 & 7.95 & 15.43 & 24.68 & 17.00 & 10.89 & 12.98 & 2.86 & 3.55 & 1.69 & 0.66 \\
\hline 1974 & 50.11 & 32.96 & 21.94 & 8.98 & 6.09 & 2.49 & 0.71 & 8.16 & 15.36 & 24.65 & 17.15 & 11.01 & 12.94 & 2.88 & 3.58 & 1.76 & 0.70 \\
\hline 1975 & 50.63 & 33.06 & 21.77 & 8.76 & 5.89 & 2.38 & 0.71 & 7.46 & 14.96 & 24.78 & 17.56 & 11.29 & 13.00 & 2.85 & 3.50 & 1.66 & 0.70 \\
\hline 1976 & 50.52 & 32.98 & 21.72 & 8.73 & 5.90 & 2.40 & 0.72 & 7.69 & 14.96 & 24.75 & 17.54 & 11.25 & 12.98 & 2.82 & 3.49 & 1.67 & 0.71 \\
\hline 1977 & 50.63 & 33.10 & 21.82 & 8.80 & 5.95 & 2.43 & 0.72 & 7.59 & 14.92 & 24.79 & 17.52 & 11.28 & 13.01 & 2.84 & 3.51 & 1.70 & 0.71 \\
\hline 1978 & 50.65 & 33.06 & 21.79 & 8.78 & 5.95 & 2.44 & 0.72 & 7.75 & 14.84 & 24.69 & 17.58 & 11.27 & 12.99 & 2.82 & 3.50 & 1.72 & 0.71 \\
\hline 1979 & 50.93 & 33.49 & 22.34 & 9.42 & 6.56 & 2.94 & 0.99 & 7.90 & 14.72 & 24.38 & 17.44 & 11.15 & 12.91 & 2.85 & 3.62 & 1.94 & 0.99 \\
\hline 1980 & 51.48 & 33.81 & 22.45 & 9.28 & 6.40 & 2.76 & 0.86 & 7.63 & 14.64 & 24.39 & 17.66 & 11.36 & 13.16 & 2.87 & 3.63 & 1.90 & 0.86 \\
\hline 1981 & 51.45 & 33.56 & 22.04 & 9.01 & 6.24 & 2.73 & 0.87 & 7.64 & 14.64 & 24.56 & 17.88 & 11.53 & 13.02 & 2.76 & 3.50 & 1.85 & 0.87 \\
\hline 1982 & 52.76 & 34.70 & 23.04 & 9.84 & 7.01 & 3.31 & 1.15 & 7.24 & 14.12 & 24.45 & 18.06 & 11.66 & 13.19 & 2.83 & 3.70 & 2.15 & 1.15 \\
\hline 1983 & 53.58 & 35.55 & 23.78 & 10.37 & 7.48 & 3.58 & 1.27 & 6.95 & 13.93 & 24.27 & 18.03 & 11.77 & 13.41 & 2.89 & 3.90 & 2.31 & 1.27 \\
\hline 1984 & 53.74 & 35.84 & 24.13 & 10.73 & 7.86 & 3.92 & 1.42 & 7.19 & 14.05 & 23.99 & 17.90 & 11.71 & 13.40 & 2.87 & 3.94 & 2.50 & 1.42 \\
\hline 1985 & 54.35 & 36.49 & 24.76 & 11.20 & 8.23 & 4.07 & 1.45 & 7.17 & 13.91 & 23.78 & 17.86 & 11.73 & 13.55 & 2.97 & 4.17 & 2.61 & 1.45 \\
\hline 1986 & 55.94 & 38.34 & 26.68 & 12.74 & 9.52 & 5.01 & 2.00 & 6.88 & 13.62 & 23.50 & 17.60 & 11.66 & 13.94 & 3.22 & 4.52 & 3.01 & 2.01 \\
\hline 1987 & 55.16 & 37.44 & 25.70 & 11.90 & 8.74 & 4.31 & 1.55 & 6.93 & 13.63 & 23.52 & 17.73 & 11.73 & 13.80 & 3.16 & 4.42 & 2.76 & 1.54 \\
\hline 1988 & 56.97 & 39.91 & 28.53 & 14.78 & 11.40 & 6.18 & 2.44 & 6.74 & 13.10 & 22.54 & 17.05 & 11.38 & 13.74 & 3.38 & 5.22 & 3.74 & 2.43 \\
\hline 1989 & 56.69 & 39.48 & 27.92 & 13.95 & 10.55 & 5.56 & 2.15 & 6.84 & 13.06 & 22.65 & 17.21 & 11.56 & 13.96 & 3.40 & 4.99 & 3.40 & 2.15 \\
\hline 1990 & 57.11 & 39.75 & 28.07 & 13.96 & 10.58 & 5.47 & 2.13 & 6.56 & 13.04 & 22.70 & 17.36 & 11.68 & 14.10 & 3.38 & 5.09 & 3.34 & 2.12 \\
\hline 1991 & 56.71 & 39.19 & 27.36 & 13.02 & 9.64 & 4.80 & 1.78 & 6.67 & 13.06 & 22.77 & 17.52 & 11.83 & 14.33 & 3.37 & 4.83 & 3.02 & 1.77 \\
\hline 1992 & 58.00 & 40.64 & 28.82 & 14.37 & 10.88 & 5.72 & 2.22 & 6.22 & 12.63 & 22.37 & 17.36 & 11.82 & 14.45 & 3.49 & 5.15 & 3.49 & 2.22 \\
\hline 1993 & 57.96 & 40.47 & 28.57 & 13.93 & 10.43 & 5.38 & 2.03 & 6.23 & 12.62 & 22.32 & 17.50 & 11.90 & 14.63 & 3.49 & 5.04 & 3.35 & 2.02 \\
\hline 1994 & 57.97 & 40.51 & 28.66 & 14.01 & 10.47 & 5.36 & 2.02 & 6.27 & 12.55 & 22.20 & 17.46 & 11.85 & 14.65 & 3.54 & 5.10 & 3.33 & 2.02 \\
\hline 1995 & 58.51 & 41.37 & 29.52 & 14.72 & 11.05 & 5.70 & 2.09 & 6.24 & 12.40 & 21.85 & 17.14 & 11.84 & 14.79 & 3.67 & 5.36 & 3.60 & 2.08 \\
\hline 1996 & 59.39 & 42.52 & 30.84 & 15.90 & 12.12 & 6.44 & 2.47 & 6.20 & 12.14 & 21.36 & 16.86 & 11.68 & 14.94 & 3.78 & 5.68 & 3.98 & 2.47 \\
\hline 1997 & 60.07 & 43.54 & 32.05 & 17.00 & 13.12 & 7.21 & 2.71 & 6.15 & 12.01 & 20.99 & 16.52 & 11.49 & 15.05 & 3.87 & 5.92 & 4.52 & 2.71 \\
\hline 1998 & 60.43 & 44.14 & 32.74 & 17.68 & 13.73 & 7.61 & 2.93 & 6.16 & 11.85 & 20.70 & 16.29 & 11.40 & 15.07 & 3.95 & 6.13 & 4.70 & 2.93 \\
\hline 1999 & 61.12 & 44.96 & 33.60 & 18.37 & 14.36 & 8.02 & 3.09 & 6.05 & 11.58 & 20.34 & 16.16 & 11.36 & 15.23 & 4.02 & 6.36 & 4.94 & 3.09 \\
\hline 2000 & 62.13 & 46.20 & 34.90 & 19.63 & 15.52 & 8.91 & 3.47 & 6.10 & 11.46 & 20.01 & 15.93 & 11.29 & 15.28 & 4.11 & 6.63 & 5.46 & 3.48 \\
\hline 2001 & 60.20 & 43.63 & 31.95 & 16.88 & 13.06 & 7.12 & 2.75 & 6.14 & 11.91 & 20.78 & 16.57 & 11.68 & 15.07 & 3.82 & 5.94 & 4.38 & 2.75 \\
\hline
\end{tabular}

Notes: Computations by authors on tax return statistics. Taxpayers are ranked by gross income (excluding capital gains and government transfers).

Income of non-filers is imputed as $20 \%$ of average income. Groups defined relative to all tax units (filers and non-filers).

Income include employer payroll taxes, realized capital gains, and imputed corporate taxes. 
Table A2. Post-tax Top Income Shares in the United States, 1960-2001

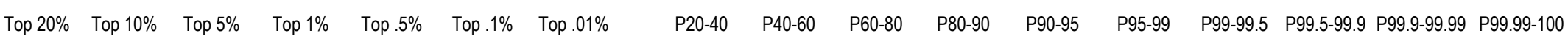

\begin{tabular}{|c|c|c|c|c|c|c|c|c|c|c|c|c|c|c|c|c|c|}
\hline 1960 & 47.36 & 30.32 & 19.50 & 7.13 & 4.55 & 1.53 & 0.34 & 8.31 & 16.68 & 25.26 & 17.02 & 10.78 & 12.30 & 2.57 & 2.99 & 1.19 & 0.34 \\
\hline 1962 & 47.56 & 30.19 & 19.17 & 6.88 & 4.36 & 1.46 & 0.32 & 7.86 & 16.35 & 25.38 & 17.35 & 10.98 & 12.22 & 2.51 & 2.88 & 1.13 & 0.32 \\
\hline 1964 & 48.09 & 30.72 & 19.71 & 7.13 & 4.51 & 1.51 & 0.34 & 7.76 & 16.12 & 25.45 & 17.34 & 10.97 & 12.48 & 2.60 & 2.96 & 1.16 & 0.35 \\
\hline 1966 & 47.77 & 30.58 & 19.73 & 7.23 & 4.61 & 1.61 & 0.39 & 8.10 & 16.20 & 25.29 & 17.16 & 10.81 & 12.41 & 2.61 & 2.96 & 1.22 & 0.39 \\
\hline 1967 & 48.49 & 31.40 & 20.49 & 7.77 & 5.04 & 1.81 & 0.44 & 8.13 & 16.06 & 24.89 & 17.05 & 10.87 & 12.64 & 2.70 & 3.20 & 1.37 & 0.44 \\
\hline 1968 & 48.29 & 31.21 & 20.33 & 7.67 & 4.97 & 1.75 & 0.41 & 8.40 & 16.21 & 24.97 & 17.04 & 10.83 & 12.55 & 2.67 & 3.17 & 1.33 & 0.41 \\
\hline 1969 & 48.07 & 30.72 & 19.79 & 7.28 & 4.70 & 1.68 & 0.43 & 8.65 & 16.47 & 25.39 & 17.31 & 10.89 & 12.41 & 2.55 & 2.97 & 1.23 & 0.43 \\
\hline 1970 & 47.08 & 29.62 & 18.56 & 6.26 & 3.85 & 1.20 & 0.25 & 8.57 & 16.36 & 25.31 & 17.44 & 11.03 & 12.23 & 2.39 & 2.62 & 0.94 & 0.25 \\
\hline 1971 & 47.84 & 30.26 & 19.06 & 6.51 & 4.03 & 1.27 & 0.26 & 8.17 & 15.97 & 25.21 & 17.56 & 11.15 & 12.46 & 2.46 & 2.72 & 1.00 & 0.27 \\
\hline 1972 & 47.52 & 30.03 & 18.91 & 6.53 & 4.07 & 1.33 & 0.30 & 8.67 & 16.07 & 25.20 & 17.46 & 11.08 & 12.31 & 2.45 & 2.71 & 1.01 & 0.30 \\
\hline 1973 & 47.47 & 29.98 & 18.88 & 6.35 & 3.93 & 1.26 & 0.26 & 8.64 & 16.08 & 25.30 & 17.47 & 11.07 & 12.48 & 2.40 & 2.66 & 0.99 & 0.26 \\
\hline 1974 & 47.85 & 30.37 & 19.22 & 6.64 & 4.16 & 1.39 & 0.30 & 8.85 & 16.05 & 25.24 & 17.47 & 11.13 & 12.54 & 2.48 & 2.76 & 1.08 & 0.30 \\
\hline 1975 & 47.96 & 30.13 & 18.76 & 6.26 & 3.87 & 1.25 & 0.28 & 8.35 & 15.83 & 25.42 & 17.81 & 11.35 & 12.46 & 2.39 & 2.61 & 0.96 & 0.28 \\
\hline 1976 & 47.98 & 30.14 & 18.78 & 6.26 & 3.88 & 1.26 & 0.27 & 8.46 & 15.78 & 25.43 & 17.81 & 11.35 & 12.47 & 2.37 & 2.61 & 0.98 & 0.28 \\
\hline 1977 & 47.99 & 30.13 & 18.71 & 6.26 & 3.90 & 1.30 & 0.30 & 8.43 & 15.78 & 25.46 & 17.85 & 11.40 & 12.42 & 2.35 & 2.59 & 1.00 & 0.30 \\
\hline 1978 & 48.42 & 30.51 & 19.08 & 6.53 & 4.12 & 1.42 & 0.34 & 8.50 & 15.51 & 25.22 & 17.91 & 11.41 & 12.52 & 2.41 & 2.69 & 1.08 & 0.34 \\
\hline 1979 & 47.74 & 30.24 & 19.17 & 6.96 & 4.55 & 1.77 & 0.52 & 8.94 & 15.72 & 25.12 & 17.49 & 11.04 & 12.17 & 2.39 & 2.76 & 1.24 & 0.52 \\
\hline 1980 & 48.28 & 30.62 & 19.44 & 7.03 & 4.58 & 1.74 & 0.48 & 8.70 & 15.68 & 25.11 & 17.64 & 11.17 & 12.37 & 2.44 & 2.83 & 1.26 & 0.48 \\
\hline 1981 & 48.31 & 30.55 & 19.32 & 7.03 & 4.64 & 1.82 & 0.53 & 8.73 & 15.68 & 25.21 & 17.75 & 11.21 & 12.26 & 2.38 & 2.80 & 1.29 & 0.53 \\
\hline 1982 & 50.23 & 32.33 & 20.90 & 8.22 & 5.68 & 2.53 & 0.85 & 8.15 & 15.01 & 24.92 & 17.89 & 11.42 & 12.64 & 2.54 & 3.13 & 1.67 & 0.85 \\
\hline 1983 & 51.14 & 33.23 & 21.71 & 8.75 & 6.10 & 2.73 & 0.93 & 7.79 & 14.79 & 24.77 & 17.90 & 11.50 & 12.92 & 2.64 & 3.36 & 1.80 & 0.93 \\
\hline 1984 & 51.33 & 33.53 & 22.07 & 9.10 & 6.47 & 3.04 & 1.06 & 8.00 & 14.88 & 24.47 & 17.78 & 11.45 & 12.92 & 2.62 & 3.42 & 1.98 & 1.06 \\
\hline 1985 & 51.92 & 34.17 & 22.70 & 9.57 & 6.82 & 3.18 & 1.10 & 8.01 & 14.76 & 24.25 & 17.74 & 11.46 & 13.09 & 2.74 & 3.63 & 2.08 & 1.10 \\
\hline 1986 & 53.52 & 36.05 & 24.66 & 11.11 & 8.12 & 4.10 & 1.62 & 7.69 & 14.46 & 23.95 & 17.45 & 11.36 & 13.48 & 2.98 & 4.00 & 2.47 & 1.62 \\
\hline 1987 & 52.42 & 34.66 & 23.19 & 10.03 & 7.18 & 3.38 & 1.17 & 7.82 & 14.59 & 24.17 & 17.75 & 11.45 & 13.15 & 2.85 & 3.79 & 2.22 & 1.17 \\
\hline 1988 & 54.60 & 37.60 & 26.47 & 13.23 & 10.12 & 5.42 & 2.12 & 7.57 & 13.93 & 23.02 & 16.99 & 11.12 & 13.23 & 3.10 & 4.70 & 3.30 & 2.12 \\
\hline 1989 & 54.29 & 37.14 & 25.87 & 12.41 & 9.30 & 4.81 & 1.83 & 7.70 & 13.89 & 23.14 & 17.14 & 11.26 & 13.42 & 3.11 & 4.48 & 2.98 & 1.83 \\
\hline 1990 & 54.75 & 37.47 & 26.11 & 12.53 & 9.41 & 4.80 & 1.84 & 7.41 & 13.89 & 23.16 & 17.27 & 11.35 & 13.57 & 3.12 & 4.60 & 2.96 & 1.84 \\
\hline 1991 & 54.21 & 36.76 & 25.23 & 11.43 & 8.33 & 4.04 & 1.47 & 7.60 & 13.94 & 23.24 & 17.45 & 11.52 & 13.78 & 3.10 & 4.28 & 2.57 & 1.47 \\
\hline 1992 & 55.35 & 37.97 & 26.42 & 12.53 & 9.36 & 4.83 & 1.86 & 7.16 & 13.62 & 22.92 & 17.38 & 11.54 & 13.87 & 3.17 & 4.53 & 2.97 & 1.86 \\
\hline 1993 & 54.86 & 37.22 & 25.53 & 11.44 & 8.31 & 4.08 & 1.49 & 7.26 & 13.74 & 23.09 & 17.63 & 11.68 & 14.06 & 3.13 & 4.22 & 2.59 & 1.49 \\
\hline 1994 & 54.50 & 36.87 & 25.25 & 11.28 & 8.17 & 3.99 & 1.47 & 7.45 & 13.77 & 23.02 & 17.62 & 11.61 & 13.94 & 3.11 & 4.18 & 2.52 & 1.47 \\
\hline 1995 & 54.85 & 37.49 & 25.84 & 11.75 & 8.57 & 4.22 & 1.51 & 7.50 & 13.64 & 22.72 & 17.35 & 11.64 & 14.06 & 3.17 & 4.35 & 2.71 & 1.51 \\
\hline 1996 & 55.62 & 38.53 & 27.02 & 12.78 & 9.50 & 4.87 & 1.83 & 7.46 & 13.41 & 22.27 & 17.09 & 11.49 & 14.20 & 3.27 & 4.63 & 3.04 & 1.83 \\
\hline 1997 & 56.44 & 39.73 & 28.42 & 14.03 & 10.62 & 5.68 & 2.11 & 7.39 & 13.20 & 21.82 & 16.69 & 11.29 & 14.34 & 3.41 & 4.92 & 3.58 & 2.11 \\
\hline 1998 & 56.69 & 40.18 & 28.97 & 14.62 & 11.16 & 6.04 & 2.30 & 7.39 & 13.06 & 21.61 & 16.49 & 11.19 & 14.30 & 3.46 & 5.12 & 3.74 & 2.30 \\
\hline 1999 & 57.33 & 40.96 & 29.79 & 15.33 & 11.80 & 6.46 & 2.47 & 7.26 & 12.80 & 21.30 & 16.36 & 11.14 & 14.42 & 3.52 & 5.33 & 3.99 & 2.47 \\
\hline 2000 & 58.41 & 42.24 & 31.13 & 16.60 & 12.95 & 7.32 & 2.83 & 7.30 & 12.62 & 20.95 & 16.14 & 11.08 & 14.50 & 3.64 & 5.63 & 4.49 & 2.83 \\
\hline 2001 & 56.42 & 39.69 & 28.30 & 14.03 & 10.67 & 5.69 & 2.18 & 7.38 & 13.20 & 21.73 & 16.71 & 11.38 & 14.24 & 3.35 & 4.98 & 3.51 & 2.18 \\
\hline
\end{tabular}

Notes: Computations by authors on tax return statistics. Taxpayers are ranked by gross income (excluding capital gains and government transfers).

Income of non-filers is imputed as $20 \%$ of average income. Groups defined relative to all tax units (filers and non-filers).

Income include employer payroll taxes, realized capital gains, and imputed corporate taxes.

Taxes include federal individual, payroll, corporate, and estate and gift taxes. 
Table A3. Average Tax Rates by Income Groups, 1960-2004

P0-100

All Indiv. Payroll Corp. Estate $\begin{array}{llllll}1960 & 21.4 & 11.4 & 3.5 & 6.0 & 0.6\end{array}$ $\begin{array}{llllll}1962 & 21.9 & 11.9 & 3.7 & 5.8 & 0.6\end{array}$ $\begin{array}{llllll}1964 & 21.1 & 10.9 & 3.8 & 5.8 & 0.6\end{array}$ $\begin{array}{llllll}1966 & 22.4 & 10.8 & 5.1 & 5.9 & 0.6\end{array}$ $\begin{array}{llllll}1967 & 22.0 & 11.0 & 5.2 & 5.2 & 0.5\end{array}$ $\begin{array}{llllll}1968 & 24.0 & 12.5 & 5.1 & 5.7 & 0.6\end{array}$ $\begin{array}{llllll}1969 & 24.5 & 12.8 & 5.8 & 5.4 & 0.5\end{array}$ $\begin{array}{llllll}1970 & 23.3 & 12.5 & 5.8 & 4.3 & 0.7\end{array}$ $\begin{array}{llllll}1971 & 22.4 & 11.3 & 6.0 & 4.4 & 0.7\end{array}$ $\begin{array}{llllll}1972 & 22.8 & 11.7 & 6.2 & 4.3 & 0.6\end{array}$ $\begin{array}{lllllll}1973 & 24.5 & 12.1 & 7.3 & 4.6 & 0.5\end{array}$ $\begin{array}{llllll}1974 & 24.8 & 12.2 & 7.7 & 4.4 & 0.5\end{array}$ $\begin{array}{llllll}1975 & 24.4 & 12.1 & 7.7 & 4.1 & 0.5\end{array}$ $\begin{array}{lllllll}1976 & 24.7 & 11.9 & 7.6 & 4.6 & 0.6\end{array}$ $\begin{array}{lllllll}1977 & 24.1 & 11.4 & 7.6 & 4.7 & 0.4\end{array}$ $\begin{array}{llllll}1978 & 24.2 & 11.3 & 7.8 & 4.8 & 0.4\end{array}$ $\begin{array}{llllll}1979 & 26.3 & 13.2 & 8.3 & 4.4 & 0.4\end{array}$ $\begin{array}{lllllll}1980 & 26.6 & 14.1 & 8.3 & 3.8 & 0.4\end{array}$ $\begin{array}{lllllll}1981 & 27.4 & 14.6 & 9.1 & 3.3 & 0.4\end{array}$ $\begin{array}{llllll}1982 & 25.3 & 13.6 & 9.2 & 2.3 & 0.3\end{array}$ $\begin{array}{llllll}1983 & 24.8 & 12.7 & 9.1 & 2.7 & 0.3\end{array}$ $\begin{array}{llllll}1984 & 25.3 & 12.6 & 9.4 & 3.0 & 0.3\end{array}$ $\begin{array}{llllll}1985 & 25.2 & 12.7 & 9.4 & 2.8 & 0.3\end{array}$ $\begin{array}{llllll}1986 & 25.2 & 12.9 & 9.2 & 2.9 & 0.2\end{array}$ $\begin{array}{llllll}1987 & 25.6 & 12.5 & 9.5 & 3.4 & 0.2\end{array}$ $\begin{array}{lllllll}1988 & 25.7 & 12.6 & 9.5 & 3.3 & 0.3\end{array}$ $\begin{array}{llllll}1989 & 25.8 & 12.6 & 9.6 & 3.3 & 0.3\end{array}$ $\begin{array}{llllll}1990 & 25.8 & 12.4 & 9.9 & 3.2 & 0.3\end{array}$ $\begin{array}{llllll}1991 & 25.6 & 12.2 & 10.1 & 2.9 & 0.3\end{array}$ $\begin{array}{lllllll}1992 & 25.8 & 12.5 & 10.0 & 3.0 & 0.3\end{array}$ $\begin{array}{llllll}1993 & 26.7 & 12.8 & 10.1 & 3.4 & 0.4\end{array}$ $\begin{array}{llllll}1994 & 27.2 & 12.9 & 10.3 & 3.7 & 0.3\end{array}$ $\begin{array}{llllll}1995 & 27.6 & 13.2 & 10.1 & 3.9 & 0.4\end{array}$ $\begin{array}{lllllll}1996 & 27.8 & 13.7 & 9.8 & 3.9 & 0.4\end{array}$ $\begin{array}{llllll}1997 & 27.5 & 13.7 & 9.5 & 3.8 & 0.5\end{array}$ $\begin{array}{llllll}1998 & 27.1 & 13.7 & 9.4 & 3.5 & 0.5\end{array}$ $\begin{array}{llllll}1999 & 27.4 & 14.3 & 9.2 & 3.4 & 0.4\end{array}$ $\begin{array}{lllllll}2000 & 27.4 & 14.6 & 9.1 & 3.3 & 0.4\end{array}$ $\begin{array}{llllll}2001 & 25.8 & 13.1 & 9.8 & 2.5 & 0.4\end{array}$
All Indiv. Payroll Corp. Estate $\begin{array}{llllll}1960 & 24.5 & 15.0 & 2.4 & 5.9 & 1.2\end{array}$ $\begin{array}{llllll}1962 & 26.1 & 15.2 & 2.5 & 7.3 & 1.1\end{array}$ $\begin{array}{llllll}1964 & 25.3 & 14.1 & 2.4 & 7.6 & 1.3\end{array}$ $\begin{array}{llllll}1966 & 26.4 & 14.1 & 3.6 & 7.6 & 1.2\end{array}$ $\begin{array}{llllll}1967 & 25.5 & 14.1 & 3.5 & 6.8 & 1.1\end{array}$ $\begin{array}{llllll}1968 & 28.2 & 16.0 & 3.5 & 7.5 & 1.2\end{array}$ $\begin{array}{lllllll}1969 & 28.0 & 16.2 & 4.0 & 6.8 & 1.1\end{array}$ $\begin{array}{lllllll}1970 & 26.7 & 16.0 & 3.9 & 5.4 & 1.3\end{array}$ $\begin{array}{llllll}1971 & 25.6 & 14.7 & 4.0 & 5.5 & 1.5\end{array}$ $\begin{array}{llllll}1972 & 26.4 & 15.5 & 4.3 & 5.3 & 1.2\end{array}$ $\begin{array}{lllllll}1973 & 28.0 & 16.0 & 5.3 & 5.7 & 1.0\end{array}$ $\begin{array}{llllll}1974 & 28.2 & 15.9 & 5.9 & 5.4 & 1.0\end{array}$ $\begin{array}{llllll}1975 & 28.4 & 16.4 & 6.1 & 4.9 & 1.0\end{array}$ $\begin{array}{llllll}1976 & 28.5 & 15.9 & 6.0 & 5.3 & 1.2\end{array}$ $\begin{array}{lllllll}1977 & 28.0 & 15.8 & 6.0 & 5.4 & 0.8\end{array}$ $\begin{array}{llllll}1978 & 27.6 & 15.1 & 6.1 & 5.6 & 0.7\end{array}$ $\begin{array}{llllll}1979 & 30.9 & 18.0 & 6.9 & 5.2 & 0.8\end{array}$ $\begin{array}{llllll}1980 & 31.2 & 18.9 & 7.1 & 4.4 & 0.7\end{array}$ $\begin{array}{lllllll}1981 & 31.8 & 19.4 & 7.9 & 3.7 & 0.7\end{array}$ $\begin{array}{lllllll}1982 & 28.9 & 17.7 & 8.1 & 2.6 & 0.5\end{array}$ $\begin{array}{lllllll}1983 & 28.2 & 16.6 & 8.1 & 3.0 & 0.5\end{array}$ $\begin{array}{lllllll}1984 & 28.7 & 16.5 & 8.4 & 3.3 & 0.5\end{array}$ $\begin{array}{lllllll}1985 & 28.6 & 16.6 & 8.3 & 3.2 & 0.5\end{array}$ $\begin{array}{llllll}1986 & 28.4 & 16.6 & 8.1 & 3.3 & 0.5\end{array}$ $\begin{array}{llllll}1987 & 29.3 & 16.7 & 8.4 & 3.7 & 0.5\end{array}$ $\begin{array}{lllllll}1988 & 28.8 & 16.5 & 8.1 & 3.8 & 0.5\end{array}$ $\begin{array}{lllllll}1989 & 29.0 & 16.4 & 8.3 & 3.7 & 0.6\end{array}$ $\begin{array}{llllll}1990 & 28.9 & 16.1 & 8.7 & 3.6 & 0.5\end{array}$ $\begin{array}{llllll}1991 & 28.8 & 16.1 & 9.0 & 3.2 & 0.5\end{array}$ $\begin{array}{llllll}1992 & 29.2 & 16.5 & 8.8 & 3.4 & 0.6\end{array}$ $\begin{array}{llllll}1993 & 30.6 & 17.2 & 8.9 & 3.9 & 0.6\end{array}$ $\begin{array}{llllll}1994 & 31.6 & 17.4 & 9.4 & 4.2 & 0.6\end{array}$ $\begin{array}{llllll}1995 & 32.1 & 18.0 & 9.0 & 4.5 & 0.7\end{array}$ $\begin{array}{lllllll}1996 & 32.3 & 18.6 & 8.6 & 4.5 & 0.7\end{array}$ $\begin{array}{llllll}1997 & 31.8 & 18.4 & 8.3 & 4.4 & 0.8\end{array}$ $\begin{array}{llllll}1998 & 31.6 & 18.6 & 8.1 & 4.1 & 0.8\end{array}$ $\begin{array}{lllllll}1999 & 31.9 & 19.2 & 7.9 & 4.0 & 0.8\end{array}$ $\begin{array}{llllll}2000 & 31.7 & 19.5 & 7.7 & 3.8 & 0.7\end{array}$ $\begin{array}{llllll}2001 & 30.4 & 18.3 & 8.6 & 2.9 & 0.7\end{array}$
All Indiv. Payroll Corp. Estate $\begin{array}{llllll}1960 & 28.0 & 16.9 & 1.7 & 7.6 & 1.8\end{array}$ $\begin{array}{llllll}1962 & 29.8 & 16.9 & 1.8 & 9.3 & 1.8\end{array}$ $\begin{array}{lllllll}1964 & 29.2 & 15.9 & 1.7 & 9.6 & 2.0\end{array}$ $\begin{array}{llllll}1966 & 30.0 & 15.9 & 2.6 & 9.7 & 1.9\end{array}$ $\begin{array}{llllll}1967 & 28.7 & 15.8 & 2.5 & 8.7 & 1.7\end{array}$ $\begin{array}{llllll}1968 & 31.7 & 18.0 & 2.5 & 9.4 & 1.8\end{array}$ $\begin{array}{lllllll}1969 & 31.3 & 18.0 & 2.9 & 8.6 & 1.8\end{array}$ $\begin{array}{llllll}1970 & 30.0 & 18.0 & 2.9 & 7.0 & 2.1\end{array}$ $\begin{array}{llllll}1971 & 28.7 & 16.4 & 3.0 & 7.0 & 2.3\end{array}$ $\begin{array}{llllll}1972 & 29.4 & 17.6 & 3.2 & 6.7 & 1.9\end{array}$ $\begin{array}{llllll}1973 & 30.9 & 18.1 & 3.9 & 7.2 & 1.6\end{array}$ $\begin{array}{llllll}1974 & 30.7 & 17.9 & 4.4 & 6.9 & 1.5\end{array}$ $\begin{array}{llllll}1975 & 31.1 & 18.8 & 4.6 & 6.1 & 1.6\end{array}$ $\begin{array}{llllll}1976 & 31.2 & 18.1 & 4.6 & 6.6 & 1.9\end{array}$ $\begin{array}{lllllll}1977 & 30.9 & 18.4 & 4.6 & 6.7 & 1.2\end{array}$ $\begin{array}{llllll}1978 & 30.1 & 17.5 & 4.6 & 6.8 & 1.2\end{array}$ $\begin{array}{llllll}1979 & 33.5 & 20.4 & 5.4 & 6.4 & 1.2\end{array}$ $\begin{array}{llllll}1980 & 33.6 & 21.4 & 5.6 & 5.4 & 1.2\end{array}$ $\begin{array}{llllll}1981 & 33.9 & 21.9 & 6.4 & 4.5 & 1.1\end{array}$ $\begin{array}{llllll}1982 & 30.4 & 19.9 & 6.5 & 3.2 & 0.8\end{array}$ $\begin{array}{llllll}1983 & 29.7 & 18.6 & 6.7 & 3.5 & 0.8\end{array}$ $\begin{array}{lllllll}1984 & 30.2 & 18.6 & 6.9 & 4.0 & 0.8\end{array}$ $\begin{array}{lllllll}1985 & 30.0 & 18.6 & 6.8 & 3.8 & 0.8\end{array}$ $\begin{array}{llllll}1986 & 29.6 & 18.5 & 6.5 & 3.9 & 0.7\end{array}$ $\begin{array}{llllll}1987 & 31.1 & 19.2 & 6.9 & 4.3 & 0.7\end{array}$ $\begin{array}{lllllll}1988 & 30.0 & 18.5 & 6.4 & 4.4 & 0.7\end{array}$ $\begin{array}{llllll}1989 & 30.2 & 18.4 & 6.6 & 4.4 & 0.9\end{array}$ $\begin{array}{llllll}1990 & 30.1 & 18.1 & 7.0 & 4.1 & 0.8\end{array}$ $\begin{array}{llllll}1991 & 30.2 & 18.2 & 7.4 & 3.8 & 0.8\end{array}$ $\begin{array}{llllll}1992 & 30.7 & 18.7 & 7.2 & 3.9 & 0.8\end{array}$ $\begin{array}{llllll}1993 & 32.6 & 19.8 & 7.3 & 4.5 & 0.9\end{array}$ $\begin{array}{llllll}1994 & 33.7 & 19.9 & 8.0 & 4.9 & 0.9\end{array}$ $\begin{array}{llllll}1995 & 34.4 & 20.6 & 7.6 & 5.2 & 1.0\end{array}$ $\begin{array}{llllll}1996 & 34.6 & 21.2 & 7.2 & 5.2 & 1.0\end{array}$ $\begin{array}{lllllll}1997 & 33.8 & 20.8 & 6.8 & 5.1 & 1.1\end{array}$ $\begin{array}{llllll}1998 & 33.7 & 21.1 & 6.7 & 4.7 & 1.2\end{array}$ $\begin{array}{llllll}1999 & 33.8 & 21.7 & 6.5 & 4.6 & 1.1\end{array}$ $\begin{array}{lllllll}2000 & 33.6 & 22.0 & 6.3 & 4.4 & 1.0\end{array}$ $\begin{array}{lllllll}2001 & 32.5 & 21.0 & 7.2 & 3.4 & 0.9\end{array}$
P95-100

All Indiv. Payroll Corp. Estate $\begin{array}{llllll}1960 & 32.5 & 18.8 & 1.1 & 9.8 & 27\end{array}$ $\begin{array}{lllllll}1962 & 34.5 & 18.8 & 1.3 & 11.8 & 2.7\end{array}$ $\begin{array}{lllllll}1964 & 33.9 & 17.6 & 1.2 & 12.1 & 3.0\end{array}$ $\begin{array}{lllllll}1966 & 34.5 & 17.7 & 1.8 & 12.1 & 2.8\end{array}$ $\begin{array}{llllll}1967 & 32.7 & 17.6 & 1.8 & 10.8 & 2.6\end{array}$ $\begin{array}{lllllll}1968 & 36.1 & 19.9 & 1.7 & 11.7 & 2.8\end{array}$ $\begin{array}{lllllll}1969 & 35.4 & 19.8 & 2.1 & 10.8 & 2.7\end{array}$ $\begin{array}{lllllll}1970 & 34.4 & 20.1 & 2.1 & 8.9 & 3.3\end{array}$ $\begin{array}{llllll}1971 & 32.9 & 18.3 & 2.2 & 8.9 & 3.5\end{array}$ $\begin{array}{llllll}1972 & 33.5 & 19.8 & 2.3 & 8.4 & 3.0\end{array}$ $\begin{array}{lllllll}1973 & 34.7 & 20.3 & 2.9 & 9.0 & 2.6\end{array}$ $\begin{array}{llllll}1974 & 34.1 & 20.0 & 3.2 & 8.5 & 2.3\end{array}$ $\begin{array}{llllll}1975 & 34.9 & 21.3 & 3.4 & 7.6 & 2.5\end{array}$ $\begin{array}{lllllll}1976 & 34.9 & 20.4 & 3.4 & 8.1 & 2.9\end{array}$ $\begin{array}{lllllll}1977 & 34.9 & 21.3 & 3.4 & 8.3 & 1.9\end{array}$ $\begin{array}{lllllll}1978 & 33.7 & 20.0 & 3.5 & 8.4 & 1.8\end{array}$ $\begin{array}{lllllll}1979 & 36.8 & 22.9 & 4.0 & 8.0 & 1.9\end{array}$ $\begin{array}{lllllll}1980 & 36.5 & 23.9 & 4.1 & 6.6 & 1.8\end{array}$ $\begin{array}{llllll}1981 & 36.3 & 24.3 & 4.8 & 5.4 & 1.8\end{array}$ $\begin{array}{llllll}1982 & 32.3 & 22.2 & 4.9 & 3.9 & 1.3\end{array}$ $\begin{array}{lllllll}1983 & 31.3 & 20.8 & 5.0 & 4.3 & 1.2\end{array}$ $\begin{array}{lllllll}1984 & 31.7 & 20.7 & 5.1 & 4.7 & 1.2\end{array}$ $\begin{array}{lllllll}1985 & 31.4 & 20.7 & 5.0 & 4.5 & 1.2\end{array}$ $\begin{array}{llllll}1986 & 30.8 & 20.4 & 4.7 & 4.6 & 1.1\end{array}$ $\begin{array}{llllll}1987 & 32.9 & 21.6 & 5.1 & 5.2 & 1.0\end{array}$ $\begin{array}{llllll}1988 & 31.1 & 20.3 & 4.5 & 5.3 & 1.0\end{array}$ $\begin{array}{llllll}1989 & 31.3 & 20.2 & 4.7 & 5.2 & 1.3\end{array}$ $\begin{array}{llllll}1990 & 31.0 & 19.9 & 5.1 & 4.9 & 1.1\end{array}$ $\begin{array}{llllll}1991 & 31.3 & 20.2 & 5.4 & 4.5 & 1.1\end{array}$ $\begin{array}{llllll}1992 & 32.0 & 20.9 & 5.2 & 4.7 & 1.2\end{array}$ $\begin{array}{lllllll}1993 & 34.5 & 22.3 & 5.4 & 5.4 & 1.4\end{array}$ $\begin{array}{llllll}1994 & 35.9 & 22.4 & 6.3 & 5.9 & 1.3\end{array}$ $\begin{array}{llllll}1995 & 36.6 & 23.1 & 5.9 & 6.2 & 1.4\end{array}$ $\begin{array}{llllll}1996 & 36.7 & 23.7 & 5.5 & 6.1 & 1.5\end{array}$ $\begin{array}{lllllll}1997 & 35.7 & 23.0 & 5.2 & 5.9 & 1.6\end{array}$ $\begin{array}{lllllll}1998 & 35.5 & 23.4 & 5.0 & 5.5 & 1.7\end{array}$ $\begin{array}{llllll}1999 & 35.6 & 24.0 & 4.9 & 5.2 & 1.5\end{array}$ $\begin{array}{llllll}2000 & 35.2 & 24.2 & 4.7 & 5.0 & 1.3\end{array}$ $\begin{array}{llllll}2001 & 34.3 & 23.5 & 5.5 & 4.0 & 1.3\end{array}$

$\begin{array}{llllll}2004 & 23.4 & 11.5 & 9.3 & 2.3 & 0.4\end{array}$

$\begin{array}{llllll}2004 & 25.7 & 14.0 & 8.9 & 2.4 & 0.5\end{array}$

$\begin{array}{llllll}2004 & 27.4 & 16.1 & 8.0 & 2.7 & 0.6\end{array}$

$2004 \quad 29.1 \quad 18.5 \quad 6.6 \quad 3.1 \quad 0.9$

Notes: Computations are based on individual tax return micro data. Groups ranked by market income excluding realized capital gains. Income (used to compute taxes) includes employer payroll taxes, realized capital gains, and imputed corporate taxes. Individual income tax is computed using TAXSIM and assuming no deduction for state and local taxes.

Corporate taxes are imputed as a proportion to total personal capital income defined as all capital income reported on tax returns and returns imputed to pension funds (and imputed to labor income).

2004 tax rates are based on 2004 tax law applied to 2000 income adjusted for income growth. 
$\underline{\mathrm{P} 99-100}$

All Indiv. Payroll Corp. Estate $\begin{array}{llllll}1960 & 44.4 & 23.6 & 0.4 & 14.4 & 6.0\end{array}$ $\begin{array}{lllllll}1962 & 46.2 & 23.3 & 0.5 & 16.5 & 6.0\end{array}$ $\begin{array}{llllll}1964 & 46.1 & 22.2 & 0.4 & 16.8 & 6.7\end{array}$ $\begin{array}{llllll}1966 & 46.2 & 22.5 & 0.7 & 16.7 & 6.2\end{array}$ $\begin{array}{llllll}1967 & 43.4 & 22.1 & 0.7 & 14.8 & 5.8\end{array}$ $\begin{array}{llllll}1968 & 47.6 & 24.8 & 0.6 & 16.1 & 6.1\end{array}$ $\begin{array}{lllllll}1969 & 46.7 & 24.3 & 0.9 & 15.4 & 6.1\end{array}$ $\begin{array}{llllll}1970 & 47.2 & 25.7 & 1.0 & 13.1 & 7.5\end{array}$ $\begin{array}{lllllll}1971 & 45.4 & 23.4 & 1.0 & 12.9 & 8.2\end{array}$ $\begin{array}{lllllll}1972 & 45.2 & 25.3 & 1.0 & 11.9 & 7.0\end{array}$ $\begin{array}{llllll}1973 & 45.7 & 26.0 & 1.3 & 12.4 & 6.0\end{array}$ $\begin{array}{lllllll}1974 & 44.4 & 25.6 & 1.5 & 11.9 & 5.3\end{array}$ $\begin{array}{llllll}1975 & 45.9 & 27.7 & 1.6 & 10.8 & 5.9\end{array}$ $\begin{array}{llllll}1976 & 46.1 & 26.2 & 1.6 & 11.5 & 6.8\end{array}$ $\begin{array}{llllll}1977 & 46.0 & 28.3 & 1.6 & 11.6 & 4.5\end{array}$ $\begin{array}{llllll}1978 & 43.6 & 26.3 & 1.6 & 11.5 & 4.2\end{array}$ $\begin{array}{lllllll}1979 & 45.6 & 28.4 & 1.8 & 11.0 & 4.3\end{array}$ $\begin{array}{llllll}1980 & 44.4 & 29.3 & 1.9 & 9.1 & 4.1\end{array}$ $\begin{array}{llllll}1981 & 43.3 & 29.3 & 2.3 & 7.6 & 4.2\end{array}$ $\begin{array}{llllll}1982 & 37.6 & 27.0 & 2.2 & 5.5 & 2.9\end{array}$ $\begin{array}{llllll}1983 & 36.5 & 25.4 & 2.2 & 6.1 & 2.8\end{array}$ $\begin{array}{lllllll}1984 & 36.7 & 25.2 & 2.3 & 6.6 & 2.6\end{array}$ $\begin{array}{llllll}1985 & 36.1 & 25.0 & 2.2 & 6.4 & 2.6\end{array}$ $\begin{array}{llllll}1986 & 34.7 & 24.0 & 2.0 & 6.3 & 2.4\end{array}$ $\begin{array}{lllllll}1987 & 37.3 & 26.1 & 2.2 & 6.9 & 2.1\end{array}$ $\begin{array}{llllll}1988 & 33.5 & 23.2 & 1.7 & 6.8 & 1.8\end{array}$ $\begin{array}{lllllll}1989 & 34.0 & 22.9 & 1.9 & 6.8 & 2.3\end{array}$ $\begin{array}{llllll}1990 & 33.4 & 22.8 & 2.0 & 6.5 & 2.0\end{array}$ $\begin{array}{llllll}1991 & 34.7 & 24.0 & 2.3 & 6.1 & 2.2\end{array}$ $\begin{array}{llllll}1992 & 35.3 & 24.7 & 2.2 & 6.3 & 2.2\end{array}$ $\begin{array}{llllll}1993 & 39.8 & 27.6 & 2.3 & 7.3 & 2.6\end{array}$ $\begin{array}{llllll}1994 & 41.4 & 27.5 & 3.4 & 8.0 & 2.4\end{array}$ $\begin{array}{llllll}1995 & 42.2 & 28.2 & 3.2 & 8.2 & 2.6\end{array}$ $\begin{array}{llllll}1996 & 41.9 & 28.4 & 3.0 & 7.9 & 2.7\end{array}$ $\begin{array}{lllllll}1997 & 40.1 & 27.0 & 2.8 & 7.5 & 2.9\end{array}$ $\begin{array}{lllllll}1998 & 39.7 & 27.3 & 2.7 & 6.8 & 2.9\end{array}$ $\begin{array}{llllll}1999 & 39.4 & 27.8 & 2.6 & 6.4 & 2.5\end{array}$ $\begin{array}{lllllll}2000 & 38.6 & 27.7 & 2.5 & 6.1 & 2.3\end{array}$ $\begin{array}{llllll}2001 & 38.3 & 27.9 & 3.0 & 5.1 & 2.2\end{array}$
All Indiv. Payroll Corp. Estate $\begin{array}{llllll}1960 & 49.1 & 25.8 & 0.3 & 15.6 & 7.5\end{array}$ $\begin{array}{lllllll}1962 & 50.8 & 25.3 & 0.4 & 17.7 & 7.4\end{array}$ $\begin{array}{lllllll}1964 & 51.0 & 24.2 & 0.3 & 18.2 & 8.4\end{array}$ $\begin{array}{lllllll}1966 & 50.8 & 24.6 & 0.5 & 17.9 & 7.8\end{array}$ $\begin{array}{lllllll}1967 & 47.5 & 23.9 & 0.5 & 15.9 & 7.2\end{array}$ $\begin{array}{lllllll}1968 & 52.0 & 26.7 & 0.4 & 17.3 & 7.6\end{array}$ $\begin{array}{lllllll}1969 & 51.0 & 26.0 & 0.6 & 16.7 & 7.7\end{array}$ $\begin{array}{lllllll}1970 & 52.4 & 28.0 & 0.7 & 14.3 & 9.4\end{array}$ $\begin{array}{lllllll}1971 & 50.6 & 25.5 & 0.7 & 14.1 & 10.3\end{array}$ $\begin{array}{lllllll}1972 & 49.9 & 27.5 & 0.8 & 12.8 & 8.8\end{array}$ $\begin{array}{lllllll}1973 & 50.1 & 28.1 & 1.0 & 13.4 & 7.6\end{array}$ $\begin{array}{lllllll}1974 & 48.6 & 28.0 & 1.1 & 12.9 & 6.7\end{array}$ $\begin{array}{lllllll}1975 & 50.4 & 30.2 & 1.2 & 11.6 & 7.4\end{array}$ $\begin{array}{llllll}1976 & 50.5 & 28.4 & 1.2 & 12.3 & 8.6\end{array}$ $\begin{array}{lllllll}1977 & 50.3 & 31.1 & 1.2 & 12.4 & 5.6\end{array}$ $\begin{array}{lllllll}1978 & 47.6 & 28.8 & 1.2 & 12.4 & 5.2\end{array}$ $\begin{array}{lllllll}1979 & 48.9 & 30.3 & 1.3 & 12.0 & 5.4\end{array}$ $\begin{array}{lllllll}1980 & 47.5 & 31.3 & 1.4 & 9.8 & 5.1\end{array}$ $\begin{array}{llllll}1981 & 46.0 & 30.9 & 1.6 & 8.3 & 5.2\end{array}$ $\begin{array}{lllllll}1982 & 39.6 & 28.4 & 1.5 & 6.1 & 3.6\end{array}$ $\begin{array}{lllllll}1983 & 38.6 & 27.0 & 1.5 & 6.7 & 3.3\end{array}$ $\begin{array}{llllll}1984 & 38.6 & 26.6 & 1.5 & 7.3 & 3.1\end{array}$ $\begin{array}{llllll}1985 & 38.1 & 26.5 & 1.4 & 7.1 & 3.1\end{array}$ $\begin{array}{llllll}1986 & 36.2 & 25.1 & 1.3 & 6.9 & 2.9\end{array}$ $\begin{array}{lllllll}1987 & 38.9 & 27.6 & 1.5 & 7.4 & 2.4\end{array}$ $\begin{array}{lllllll}1988 & 34.1 & 23.7 & 1.1 & 7.3 & 2.0\end{array}$ $\begin{array}{llllll}1989 & 34.6 & 23.5 & 1.2 & 7.3 & 2.6\end{array}$ $\begin{array}{llllll}1990 & 34.0 & 23.4 & 1.3 & 7.0 & 2.3\end{array}$ $\begin{array}{llllll}1991 & 35.7 & 25.0 & 1.6 & 6.6 & 2.5\end{array}$ $\begin{array}{lllllll}1992 & 36.2 & 25.7 & 1.4 & 6.7 & 2.4\end{array}$ $\begin{array}{lllllll}1993 & 41.6 & 29.3 & 1.5 & 7.9 & 2.9\end{array}$ $\begin{array}{llllll}1994 & 43.2 & 29.0 & 2.7 & 8.7 & 2.7\end{array}$ $\begin{array}{lllllll}1995 & 43.9 & 29.6 & 2.6 & 8.8 & 2.9\end{array}$ $\begin{array}{llllll}1996 & 43.3 & 29.6 & 2.4 & 8.4 & 3.0\end{array}$ $\begin{array}{llllll}1997 & 41.3 & 28.0 & 2.2 & 7.9 & 3.2\end{array}$ $\begin{array}{llllll}1998 & 40.8 & 28.2 & 2.2 & 7.2 & 3.2\end{array}$ $\begin{array}{llllll}1999 & 40.3 & 28.7 & 2.1 & 6.7 & 2.8\end{array}$ $\begin{array}{lllllll}2000 & 39.4 & 28.6 & 21 & 6.3 & 2.4\end{array}$ $\begin{array}{llllll}2001 & 39.4 & 29.0 & 2.4 & 5.4 & 2.4\end{array}$

\section{P99.9-100}

All Indiv. Payroll Corp. Estate $\begin{array}{llllll}1960 & 60.0 & 29.5 & 0.1 & 18.4 & 11.8\end{array}$ $\begin{array}{lllllll}1962 & 60.7 & 28.3 & 0.2 & 20.2 & 12.1\end{array}$ $\begin{array}{llllll}1964 & 61.5 & 26.9 & 0.1 & 20.8 & 13.6\end{array}$ $\begin{array}{llllll}1966 & 60.6 & 27.6 & 0.2 & 20.5 & 12.3\end{array}$ $\begin{array}{lllllll}1967 & 56.3 & 26.5 & 0.2 & 18.1 & 11.5\end{array}$ $\begin{array}{lllllll}1968 & 61.0 & 29.2 & 0.2 & 19.6 & 12.1\end{array}$ $\begin{array}{llllll}1969 & 60.0 & 28.0 & 0.3 & 19.2 & 12.5\end{array}$ $\begin{array}{llllll}1970 & 63.9 & 31.4 & 0.3 & 16.8 & 15.4\end{array}$ $\begin{array}{lllllll}1971 & 62.4 & 28.6 & 0.3 & 16.5 & 17.0\end{array}$ $\begin{array}{llllll}1972 & 60.5 & 30.8 & 0.4 & 14.9 & 14.5\end{array}$ $\begin{array}{lllllll}1973 & 60.1 & 31.4 & 0.5 & 15.7 & 12.5\end{array}$ $\begin{array}{lllllll}1974 & 58.0 & 31.8 & 0.5 & 15.1 & 10.5\end{array}$ $\begin{array}{llllll}1975 & 60.3 & 34.1 & 0.6 & 13.8 & 11.8\end{array}$ $\begin{array}{llllll}1976 & 60.6 & 31.8 & 0.6 & 14.4 & 13.7\end{array}$ $\begin{array}{lllllll}1977 & 59.2 & 35.3 & 0.6 & 14.5 & 8.9\end{array}$ $\begin{array}{lllllll}1978 & 56.0 & 32.5 & 0.6 & 14.7 & 8.2\end{array}$ $\begin{array}{lllllll}1979 & 55.7 & 32.4 & 0.6 & 14.4 & 8.3\end{array}$ $\begin{array}{lllllll}1980 & 53.7 & 33.7 & 0.6 & 11.6 & 7.8\end{array}$ $\begin{array}{llllll}1981 & 51.5 & 33.0 & 0.7 & 9.9 & 7.9\end{array}$ $\begin{array}{lllllll}1982 & 43.0 & 29.7 & 0.6 & 7.5 & 5.2\end{array}$ $\begin{array}{lllllll}1983 & 42.5 & 29.1 & 0.6 & 8.0 & 4.7\end{array}$ $\begin{array}{lllllll}1984 & 42.2 & 28.7 & 0.6 & 8.6 & 4.2\end{array}$ $\begin{array}{lllllll}1985 & 41.5 & 28.4 & 0.6 & 8.3 & 4.2\end{array}$ $\begin{array}{llllll}1986 & 38.8 & 26.3 & 0.5 & 8.1 & 4.0\end{array}$ $\begin{array}{lllllll}1987 & 41.6 & 29.5 & 0.6 & 8.4 & 3.1\end{array}$ $\begin{array}{lllllll}1988 & 34.9 & 23.9 & 0.4 & 8.2 & 2.4\end{array}$ $\begin{array}{lllllll}1989 & 35.8 & 23.7 & 0.5 & 8.4 & 3.2\end{array}$ $\begin{array}{lllllll}1990 & 35.0 & 23.7 & 0.5 & 7.9 & 2.8\end{array}$ $\begin{array}{lllllll}1991 & 37.4 & 26.0 & 0.6 & 7.5 & 3.1\end{array}$ $\begin{array}{lllllll}1992 & 37.4 & 26.6 & 0.5 & 7.4 & 2.9\end{array}$ $\begin{array}{lllllll}1993 & 44.5 & 31.3 & 0.6 & 8.9 & 3.6\end{array}$ $\begin{array}{lllllll}1994 & 45.9 & 30.8 & 1.6 & 10.1 & 3.4\end{array}$ $\begin{array}{lllllll}1995 & 46.3 & 31.2 & 1.6 & 10.1 & 3.5\end{array}$ $\begin{array}{lllllll}1996 & 45.4 & 30.8 & 1.5 & 9.5 & 3.6\end{array}$ $\begin{array}{lllllll}1997 & 42.8 & 28.9 & 1.4 & 8.8 & 3.7\end{array}$ $\begin{array}{llllll}1998 & 42.2 & 29.2 & 1.5 & 7.8 & 3.7\end{array}$ $\begin{array}{lllllll}1999 & 41.4 & 29.7 & 1.5 & 7.1 & 3.1\end{array}$ $\begin{array}{lllllll}2000 & 40.3 & 29.5 & 1.5 & 6.6 & 27\end{array}$ $\begin{array}{lllllll}2001 & 40.7 & 30.3 & 1.7 & 5.9 & 2.8\end{array}$

P99.99-100

All Indiv. Payroll Corp. Estate $\begin{array}{llllll}1960 & 71.4 & 31.5 & 0.0 & 22.3 & 17.6\end{array}$ $\begin{array}{lllllll}1962 & 71.0 & 29.1 & 0.1 & 23.6 & 18.2\end{array}$ $\begin{array}{lllllll}1964 & 72.1 & 27.6 & 0.0 & 24.2 & 20.3\end{array}$ $\begin{array}{llllll}1966 & 70.2 & 28.5 & 0.1 & 23.5 & 18 .\end{array}$ $\begin{array}{lllllll}1967 & 64.9 & 27.2 & 0.1 & 20.5 & 17.0\end{array}$ $\begin{array}{lllllll}1968 & 69.4 & 29.2 & 0.1 & 21.8 & 18.4\end{array}$ $\begin{array}{lllllll}1969 & 68.0 & 27.1 & 0.1 & 22.0 & 18.9\end{array}$ $\begin{array}{lllllll}1970 & 75.2 & 31.8 & 0.1 & 19.9 & 23.4\end{array}$ $\begin{array}{lllllll}1971 & 74.1 & 28.8 & 0.1 & 19.4 & 25.8\end{array}$ $\begin{array}{lllllll}1972 & 70.8 & 31.3 & 0.1 & 17.5 & 21.8\end{array}$ $\begin{array}{lllllll}1973 & 70.8 & 32.5 & 0.2 & 18.5 & 19.6\end{array}$ $\begin{array}{lllllll}1974 & 67.7 & 33.5 & 0.2 & 17.8 & 16.2\end{array}$ $\begin{array}{lllllll}1975 & 70.2 & 35.6 & 0.2 & 16.7 & 17.8\end{array}$ $\begin{array}{lllllll}1976 & 71.3 & 33.2 & 0.2 & 17.5 & 20.3\end{array}$ $\begin{array}{lllllll}1977 & 68.0 & 37.0 & 0.2 & 17.6 & 13.2\end{array}$ $\begin{array}{lllllll}1978 & 64.4 & 34.3 & 0.2 & 17.8 & 12.1\end{array}$ $\begin{array}{lllllll}1979 & 61.5 & 32.0 & 0.2 & 17.4 & 12.0\end{array}$ $\begin{array}{lllllll}1980 & 59.6 & 34.7 & 0.2 & 13.8 & 11.0\end{array}$ $\begin{array}{lllllll}1981 & 56.1 & 32.8 & 0.2 & 12.0 & 11.1\end{array}$ $\begin{array}{lllllll}1982 & 44.9 & 29.1 & 0.2 & 8.9 & 6.7\end{array}$ $\begin{array}{lllllll}1983 & 45.1 & 29.8 & 0.2 & 9.3 & 5.8\end{array}$ $\begin{array}{llllll}1984 & 44.5 & 29.3 & 0.2 & 10.0 & 5.0\end{array}$ $\begin{array}{llllll}1985 & 43.2 & 28.8 & 0.2 & 9.1 & 5.1\end{array}$ $\begin{array}{lllllll}1986 & 39.3 & 25.7 & 0.1 & 8.7 & 4.7\end{array}$ $\begin{array}{lllllll}1987 & 43.8 & 29.9 & 0.2 & 10.0 & 3.7\end{array}$ $\begin{array}{lllllll}1988 & 35.4 & 23.6 & 0.1 & 9.2 & 2.5\end{array}$ $\begin{array}{llllll}1989 & 36.8 & 23.6 & 0.1 & 9.5 & 3.6\end{array}$ $\begin{array}{llllll}1990 & 35.8 & 23.5 & 0.1 & 9.1 & 3.1\end{array}$ $\begin{array}{lllllll}1991 & 38.5 & 26.1 & 0.2 & 8.7 & 3.6\end{array}$ $\begin{array}{lllllll}1992 & 38.0 & 26.8 & 0.1 & 8.0 & 3.1\end{array}$ $\begin{array}{lllllll}1993 & 46.0 & 31.8 & 0.2 & 10.0 & 4.0\end{array}$ $\begin{array}{llllll}1994 & 47.1 & 30.9 & 1.0 & 11.5 & 3.8\end{array}$ $\begin{array}{lllllll}1995 & 47.8 & 31.6 & 1.0 & 11.2 & 4.0\end{array}$ $\begin{array}{lllllll}1996 & 46.5 & 31.1 & 1.0 & 10.4 & 4.0\end{array}$ $\begin{array}{llllll}1997 & 43.6 & 29.5 & 1.1 & 9.1 & 4.0\end{array}$ $\begin{array}{lllllll}1998 & 42.7 & 29.8 & 1.2 & 7.9 & 3.9\end{array}$ $\begin{array}{llllll}1999 & 41.9 & 30.4 & 1.3 & 6.9 & 3.2\end{array}$ $\begin{array}{llllll}2000 & 40.7 & 30.2 & 1.3 & 6.4 & 2.7\end{array}$ $\begin{array}{lllllll}2001 & 41.3 & 30.9 & 1.4 & 6.0 & 3.0\end{array}$ 
Table A3. Average Tax Rates by Income Groups, 1960-2004 (continued 3)

\begin{tabular}{|c|c|c|c|c|c|c|c|c|c|c|c|c|c|c|c|c|c|c|c|c|c|c|c|}
\hline \multicolumn{6}{|c|}{$\mathrm{P} 0-20$} & \multicolumn{7}{|c|}{ P20-40 } & \multicolumn{5}{|c|}{ P40-60 } & \multicolumn{6}{|c|}{ P60-80 } \\
\hline & All & Indiv. & Payroll & Corp. & Estate & & All & Indiv. & Payroll & Corp. & Estate & & All & Indiv. & Payroll & Corp. & Estate & & All & Indiv. & Payroll & Corp. & Estate \\
\hline 1960 & 14.1 & 0.8 & 3.7 & 9.6 & 0.0 & 1960 & 13.9 & 4.9 & 4.1 & 4.9 & 0.0 & 1960 & 15.9 & 7.8 & 4.8 & 3.4 & 0.0 & 1960 & 16.7 & 9.4 & 4.9 & 2.5 & 0.0 \\
\hline 1962 & 15.5 & 0.8 & 4.0 & 10.8 & 0.0 & 1962 & 16.9 & 5.0 & 4.6 & 7.3 & 0.0 & 1962 & 17.9 & 8.1 & 5.3 & 4.6 & 0.0 & 1962 & 18.0 & 9.8 & 5.0 & 3.2 & 0.0 \\
\hline 1964 & 13.9 & 0.4 & 4.4 & 9.1 & 0.0 & 1964 & 16.0 & 4.1 & 4.7 & 7.2 & 0.0 & 1964 & 16.9 & 7.1 & 5.6 & 4.2 & 0.0 & 1964 & 17.2 & 8.9 & 5.1 & 3.2 & 0.0 \\
\hline 1966 & 15.8 & 1.0 & 5.6 & 9.2 & 0.0 & 1966 & 17.3 & 4.5 & 6.0 & 6.8 & 0.0 & 1966 & 18.8 & 7.4 & 6.8 & 4.6 & 0.0 & 1966 & 19.1 & 8.9 & 7.0 & 3.2 & 0.0 \\
\hline 1967 & 15.1 & 1.5 & 5.8 & 7.8 & 0.0 & 1967 & 17.2 & 5.1 & 6.4 & 5.7 & 0.0 & 1967 & 18.7 & 7.6 & 7.2 & 3.8 & 0.0 & 1967 & 19.0 & 9.0 & 7.1 & 2.9 & 0.0 \\
\hline 1968 & 15.1 & 1.9 & 5.6 & 7.6 & 0.0 & 1968 & 18.2 & 6.1 & 5.9 & 6.1 & 0.0 & 1968 & 19.7 & 8.8 & 6.8 & 4.1 & 0.0 & 1968 & 20.6 & 10.3 & 7.1 & 3.2 & 0.0 \\
\hline 1969 & 16.3 & 2.4 & 6.6 & 7.4 & 0.0 & 1969 & 19.5 & 6.6 & 6.9 & 5.9 & 0.0 & 1969 & 21.1 & 9.3 & 7.9 & 4.0 & 0.0 & 1969 & 21.7 & 10.9 & 7.8 & 3.0 & 0.0 \\
\hline 1970 & 15.1 & 2.2 & 7.1 & 5.8 & 0.0 & 1970 & 18.5 & 6.2 & 7.0 & 5.3 & 0.0 & 1970 & 20.2 & 8.9 & 7.9 & 3.4 & 0.0 & 1970 & 20.7 & 10.6 & 7.7 & 2.4 & 0.0 \\
\hline 1971 & 15.0 & 0.7 & 7.2 & 7.1 & 0.0 & 1971 & 16.9 & 3.9 & 7.4 & 5.6 & 0.0 & 1971 & 19.5 & 7.6 & 8.5 & 3.3 & 0.0 & 1971 & 20.1 & 9.6 & 8.0 & 2.6 & 0.0 \\
\hline 1972 & 14.2 & 0.6 & 7.1 & 6.5 & 0.0 & 1972 & 16.6 & 3.8 & 7.4 & 5.4 & 0.0 & 1972 & 19.7 & 7.7 & 8.4 & 3.6 & 0.0 & 1972 & 20.6 & 9.6 & 8.3 & 2.7 & 0.0 \\
\hline 1973 & 15.4 & 0.5 & 8.1 & 6.8 & 0.0 & 1973 & 18.0 & 4.4 & 8.4 & 5.3 & 0.0 & 1973 & 21.4 & 8.2 & 9.4 & 3.8 & 0.0 & 1973 & 22.6 & 10.2 & 9.6 & 2.9 & 0.0 \\
\hline 1974 & 15.1 & 0.6 & 8.3 & 6.2 & 0.0 & 1974 & 18.4 & 5.0 & 8.6 & 4.8 & 0.0 & 1974 & 21.4 & 8.5 & 9.4 & 3.5 & 0.0 & 1974 & 23.0 & 10.4 & 9.9 & 2.7 & 0.0 \\
\hline 1975 & 13.8 & -0.4 & 8.6 & 5.5 & 0.0 & 1975 & 15.4 & 2.0 & 8.4 & 5.0 & 0.0 & 1975 & 20.0 & 7.3 & 9.3 & 3.4 & 0.0 & 1975 & 22.4 & 10.0 & 9.8 & 2.7 & 0.0 \\
\hline 1976 & 15.2 & 0.5 & 8.3 & 6.5 & 0.0 & 1976 & 17.1 & 3.5 & 8.3 & 5.4 & 0.0 & 1976 & 20.6 & 7.4 & 9.1 & 4.1 & 0.0 & 1976 & 22.7 & 9.9 & 9.7 & 3.1 & 0.0 \\
\hline 1977 & 14.4 & -0.3 & 8.6 & 6.1 & 0.0 & 1977 & 15.7 & 1.9 & 8.3 & 5.4 & 0.0 & 1977 & 19.7 & 6.5 & 9.0 & 4.2 & 0.0 & 1977 & 22.0 & 9.1 & 9.6 & 3.3 & 0.0 \\
\hline 1978 & 14.7 & -0.2 & 8.8 & 6.1 & 0.0 & 1978 & 16.9 & 2.7 & 8.7 & 5.4 & 0.0 & 1978 & 20.8 & 7.2 & 9.3 & 4.4 & 0.0 & 1978 & 22.6 & 9.3 & 9.9 & 3.4 & 0.0 \\
\hline 1979 & 14.5 & -0.2 & 8.7 & 5.9 & 0.0 & 1979 & 16.6 & 3.0 & 8.9 & 4.7 & 0.0 & 1979 & 21.3 & 8.0 & 9.5 & 3.8 & 0.0 & 1979 & 24.1 & 10.9 & 10.0 & 3.1 & 0.0 \\
\hline 1980 & 13.5 & -0.3 & 9.2 & 4.6 & 0.0 & 1980 & 16.3 & 3.4 & 8.9 & 4.1 & 0.0 & 1980 & 21.4 & 8.6 & 9.4 & 3.5 & 0.0 & 1980 & 24.5 & 11.7 & 10.0 & 2.8 & 0.0 \\
\hline 1981 & 13.7 & -0.2 & 9.9 & 4.0 & 0.0 & 1981 & 17.1 & 4.0 & 9.6 & 3.5 & 0.0 & 1981 & 22.2 & 9.0 & 10.1 & 3.0 & 0.0 & 1981 & 25.5 & 12.3 & 10.7 & 2.4 & 0.0 \\
\hline 1982 & 12.9 & -0.2 & 10.5 & 2.7 & 0.0 & 1982 & 15.9 & 3.5 & 9.7 & 2.6 & 0.0 & 1982 & 20.6 & 8.3 & 10.3 & 2.0 & 0.0 & 1982 & 23.9 & 11.4 & 10.7 & 1.8 & 0.0 \\
\hline 1983 & 13.9 & 0.3 & 9.5 & 4.0 & 0.0 & 1983 & 15.6 & 3.1 & 9.3 & 3.2 & 0.0 & 1983 & 20.2 & 7.6 & 10.0 & 2.6 & 0.0 & 1983 & 23.2 & 10.5 & 10.6 & 2.1 & 0.0 \\
\hline 1984 & 14.2 & 0.0 & 9.8 & 4.3 & 0.0 & 1984 & 16.9 & 3.7 & 9.8 & 3.4 & 0.0 & 1984 & 20.9 & 7.7 & 10.4 & 2.8 & 0.0 & 1984 & 23.8 & 10.4 & 11.1 & 2.3 & 0.0 \\
\hline 1985 & 14.2 & 0.2 & 10.0 & 4.0 & 0.0 & 1985 & 16.5 & 3.7 & 9.8 & 3.1 & 0.0 & 1985 & 20.7 & 7.7 & 10.4 & 2.7 & 0.0 & 1985 & 23.7 & 10.5 & 11.1 & 2.1 & 0.0 \\
\hline 1986 & 14.1 & 0.6 & 9.2 & 4.3 & 0.0 & 1986 & 16.3 & 3.6 & 9.6 & 3.1 & 0.0 & 1986 & 20.5 & 7.7 & 10.2 & 2.7 & 0.0 & 1986 & 23.7 & 10.5 & 11.1 & 2.2 & 0.0 \\
\hline 1987 & 16.0 & 0.4 & 10.1 & 5.5 & 0.0 & 1987 & 16.1 & 2.4 & 9.7 & 4.0 & 0.0 & 1987 & 20.4 & 6.7 & 10.5 & 3.2 & 0.0 & 1987 & 23.5 & 9.6 & 11.3 & 2.6 & 0.0 \\
\hline 1988 & 16.1 & 0.9 & 11.0 & 4.2 & 0.0 & 1988 & 16.6 & 2.8 & 10.2 & 3.6 & 0.0 & 1988 & 21.1 & 7.1 & 11.0 & 2.9 & 0.0 & 1988 & 24.2 & 9.9 & 11.8 & 2.4 & 0.0 \\
\hline 1989 & 15.5 & 0.5 & 11.2 & 3.8 & 0.0 & 1989 & 16.5 & 2.7 & 10.2 & 3.5 & 0.0 & 1989 & 21.2 & 7.3 & 11.0 & 2.9 & 0.0 & 1989 & 24.2 & 10.1 & 11.6 & 2.5 & 0.0 \\
\hline 1990 & 15.9 & 0.3 & 11.6 & 4.0 & 0.0 & 1990 & 16.2 & 2.1 & 10.6 & 3.4 & 0.0 & 1990 & 21.0 & 7.0 & 11.2 & 2.8 & 0.0 & 1990 & 24.3 & 10.0 & 11.9 & 2.4 & 0.0 \\
\hline 1991 & 15.5 & 0.1 & 11.3 & 4.1 & 0.0 & 1991 & 15.1 & 1.3 & 10.6 & 3.2 & 0.0 & 1991 & 20.5 & 6.6 & 11.3 & 2.6 & 0.0 & 1991 & 24.0 & 9.8 & 12.0 & 2.2 & 0.0 \\
\hline 1992 & 15.6 & -0.4 & 11.9 & 4.2 & 0.0 & 1992 & 14.7 & 0.6 & 10.7 & 3.4 & 0.0 & 1992 & 20.0 & 6.1 & 11.2 & 2.7 & 0.0 & 1992 & 24.0 & 9.7 & 12.2 & 2.2 & 0.0 \\
\hline 1993 & 16.0 & -0.3 & 11.1 & 5.2 & 0.0 & 1993 & 14.6 & 0.1 & 10.7 & 3.8 & 0.0 & 1993 & 20.2 & 6.0 & 11.3 & 3.0 & 0.0 & 1993 & 24.1 & 9.6 & 12.2 & 2.4 & 0.0 \\
\hline 1994 & 14.6 & -1.9 & 11.4 & 5.1 & 0.0 & 1994 & 13.5 & -1.1 & 10.7 & 4.0 & 0.0 & 1994 & 20.1 & 5.7 & 11.4 & 3.0 & 0.0 & 1994 & 24.5 & 9.8 & 12.2 & 2.6 & 0.0 \\
\hline 1995 & 13.3 & -3.4 & 11.7 & 5.0 & 0.0 & 1995 & 13.0 & -1.7 & 10.7 & 4.0 & 0.0 & 1995 & 20.4 & 5.9 & 11.3 & 3.2 & 0.0 & 1995 & 24.7 & 9.9 & 12.0 & 2.8 & 0.0 \\
\hline 1996 & 13.7 & -2.6 & 11.3 & 5.0 & 0.0 & 1996 & 13.1 & -1.4 & 10.6 & 3.9 & 0.0 & 1996 & 20.2 & 5.9 & 11.2 & 3.1 & 0.0 & 1996 & 24.7 & 10.1 & 11.9 & 2.7 & 0.0 \\
\hline 1997 & 12.8 & -3.0 & 11.0 & 4.9 & 0.0 & 1997 & 12.8 & -1.4 & 10.6 & 3.6 & 0.0 & 1997 & 20.3 & 6.1 & 11.1 & 3.0 & 0.0 & 1997 & 24.6 & 10.1 & 11.8 & 2.7 & 0.0 \\
\hline 1998 & 12.9 & -2.4 & 10.5 & 4.9 & 0.0 & 1998 & 12.6 & -1.4 & 10.7 & 3.3 & 0.0 & 1998 & 19.7 & 5.8 & 11.1 & 2.8 & 0.0 & 1998 & 23.9 & 9.7 & 11.7 & 2.5 & 0.0 \\
\hline 1999 & 12.7 & -2.3 & 10.5 & 4.6 & 0.0 & 1999 & 12.8 & -1.0 & 10.6 & 3.1 & 0.0 & 1999 & 19.7 & 6.1 & 11.1 & 2.6 & 0.0 & 1999 & 23.9 & 9.9 & 11.6 & 2.4 & 0.0 \\
\hline 2000 & 12.8 & -1.9 & 10.4 & 4.3 & 0.0 & 2000 & 13.1 & -0.4 & 10.6 & 2.9 & 0.0 & 2000 & 20.0 & 6.4 & 11.2 & 2.4 & 0.0 & 2000 & 23.9 & 10.1 & 11.6 & 2.2 & 0.0 \\
\hline 2001 & 11.4 & -3.9 & 12.3 & 3.1 & 0.0 & 2001 & 10.7 & -2.5 & 10.9 & 2.4 & 0.0 & 2001 & 17.8 & 4.3 & 11.5 & 1.9 & 0.0 & 2001 & 22.4 & 8.8 & 11.9 & 1.7 & 0.0 \\
\hline 2004 & 10.5 & -2.9 & 10.4 & 3.0 & 0.0 & 2004 & 9.4 & -3.2 & 10.6 & 2.0 & 0.0 & 2004 & 16.1 & 3.2 & 11.2 & 1.7 & 0.0 & 2004 & 20.5 & 7.3 & 11.6 & 1.6 & 0.0 \\
\hline
\end{tabular}


Table A3. Average Tax Rates by Income Groups, 1960-2004 (continued 4)

$\underline{\mathrm{P} 80-90}$

All Indiv. Payroll Corp. Estate $\begin{array}{llllll}1960 & 17.4 & 11.2 & 3.8 & 2.4 & 0.0\end{array}$ $\begin{array}{llllll}1962 & 18.6 & 11.6 & 3.8 & 3.2 & 0.0\end{array}$ $\begin{array}{llllll}1964 & 17.6 & 10.5 & 3.8 & 3.2 & 0.0\end{array}$ $\begin{array}{llllll}1966 & 19.2 & 10.4 & 5.5 & 3.3 & 0.0\end{array}$ $\begin{array}{llllll}1967 & 19.0 & 10.5 & 5.5 & 3.0 & 0.0\end{array}$ $\begin{array}{llllll}1968 & 21.0 & 12.0 & 5.8 & 3.3 & 0.0\end{array}$ $\begin{array}{llllll}1969 & 21.6 & 12.6 & 6.1 & 3.0 & 0.0\end{array}$ $\begin{array}{llllll}1970 & 20.5 & 12.2 & 5.8 & 2.4 & 0.0\end{array}$ $\begin{array}{llllll}1971 & 19.9 & 11.2 & 6.0 & 2.7 & 0.0\end{array}$ $\begin{array}{llllll}1972 & 20.5 & 11.6 & 6.3 & 2.6 & 0.0\end{array}$ $\begin{array}{llllll}1973 & 22.5 & 11.9 & 7.8 & 2.8 & 0.0\end{array}$ $\begin{array}{lllllll}1974 & 23.4 & 12.0 & 8.8 & 2.6 & 0.0\end{array}$ $\begin{array}{llllll}1975 & 23.3 & 11.9 & 8.8 & 2.6 & 0.0\end{array}$ $\begin{array}{llllll}1976 & 23.6 & 11.9 & 8.8 & 2.9 & 0.0\end{array}$ $\begin{array}{lllllll}1977 & 22.7 & 10.9 & 8.8 & 3.0 & 0.0\end{array}$ $\begin{array}{llllll}1978 & 22.8 & 10.8 & 8.8 & 3.3 & 0.0\end{array}$ $\begin{array}{lllllll}1979 & 26.1 & 13.2 & 9.9 & 2.9 & 0.0\end{array}$ $\begin{array}{llllll}1980 & 26.7 & 14.2 & 10.0 & 2.6 & 0.0\end{array}$ $\begin{array}{llllll}1981 & 27.9 & 14.8 & 10.8 & 2.3 & 0.0\end{array}$ $\begin{array}{lllllll}1982 & 26.1 & 13.5 & 11.0 & 1.6 & 0.0\end{array}$ $\begin{array}{llllll}1983 & 25.3 & 12.5 & 10.9 & 1.9 & 0.0\end{array}$ $\begin{array}{lllllll}1984 & 25.8 & 12.4 & 11.3 & 2.1 & 0.0\end{array}$ $\begin{array}{lllllll}1985 & 25.7 & 12.4 & 11.4 & 2.0 & 0.0\end{array}$ $\begin{array}{llllll}1986 & 25.8 & 12.4 & 11.3 & 2.0 & 0.0\end{array}$ $\begin{array}{lllllll}1987 & 25.5 & 11.5 & 11.6 & 2.4 & 0.0\end{array}$ $\begin{array}{llllll}1988 & 26.0 & 11.7 & 12.2 & 2.2 & 0.0\end{array}$ $\begin{array}{llllll}1989 & 26.2 & 11.8 & 12.1 & 2.3 & 0.0\end{array}$ $\begin{array}{llllll}1990 & 26.2 & 11.7 & 12.4 & 2.2 & 0.0\end{array}$ $\begin{array}{llllll}1991 & 25.8 & 11.4 & 12.4 & 2.0 & 0.0\end{array}$ $\begin{array}{lllllll}1992 & 25.7 & 11.3 & 12.4 & 2.0 & 0.0\end{array}$ $\begin{array}{llllll}1993 & 26.1 & 11.4 & 12.4 & 2.3 & 0.0\end{array}$ $\begin{array}{llllll}1994 & 26.5 & 11.6 & 12.5 & 2.5 & 0.0\end{array}$ $\begin{array}{lllllll}1995 & 26.7 & 11.7 & 12.3 & 2.6 & 0.0\end{array}$ $\begin{array}{llllll}1996 & 26.8 & 12.0 & 12.2 & 2.6 & 0.0\end{array}$ $\begin{array}{lllllll}1997 & 26.7 & 12.1 & 12.0 & 2.6 & 0.0\end{array}$ $\begin{array}{llllll}1998 & 26.2 & 11.8 & 12.0 & 2.4 & 0.0\end{array}$ $\begin{array}{llllll}1999 & 26.4 & 12.2 & 11.9 & 2.4 & 0.0\end{array}$ $\begin{array}{lllllll}2000 & 26.4 & 12.2 & 11.9 & 2.3 & 0.0\end{array}$ $\begin{array}{llllll}2001 & 25.1 & 11.1 & 12.3 & 1.7 & 0.0\end{array}$
All Indiv. Payroll Corp. Estate $\begin{array}{llllll}1960 & 18.7 & 12.7 & 2.9 & 3.1 & 0.0\end{array}$ $\begin{array}{llllll}1962 & 20.1 & 13.0 & 2.9 & 4.1 & 0.0\end{array}$ $\begin{array}{llllll}1964 & 19.1 & 12.0 & 2.9 & 4.2 & 0.0\end{array}$ $\begin{array}{llllll}1966 & 20.3 & 11.8 & 4.3 & 4.2 & 0.0\end{array}$ $\begin{array}{lllllll}1967 & 20.0 & 11.8 & 4.2 & 4.0 & 0.0\end{array}$ $\begin{array}{lllllll}1968 & 22.1 & 13.5 & 4.4 & 4.2 & 0.0\end{array}$ $\begin{array}{lllllll}1969 & 22.6 & 14.0 & 4.7 & 3.8 & 0.0\end{array}$ $\begin{array}{llllll}1970 & 21.4 & 13.7 & 4.5 & 3.2 & 0.0\end{array}$ $\begin{array}{llllll}1971 & 20.3 & 12.5 & 4.7 & 3.2 & 0.0\end{array}$ $\begin{array}{llllll}1972 & 21.4 & 13.2 & 4.9 & 3.3 & 0.0\end{array}$ $\begin{array}{lllllll}1973 & 23.4 & 13.7 & 6.0 & 3.6 & 0.0\end{array}$ $\begin{array}{llllll}1974 & 24.0 & 13.6 & 6.7 & 3.6 & 0.0\end{array}$ $\begin{array}{llllll}1975 & 24.0 & 14.0 & 6.9 & 3.1 & 0.0\end{array}$ $\begin{array}{llllll}1976 & 24.1 & 13.6 & 6.9 & 3.6 & 0.0\end{array}$ $\begin{array}{lllllll}1977 & 23.3 & 12.8 & 6.8 & 3.7 & 0.0\end{array}$ $\begin{array}{lllllll}1978 & 23.3 & 12.5 & 7.0 & 3.8 & 0.0\end{array}$ $\begin{array}{llllll}1979 & 27.0 & 15.4 & 8.3 & 3.4 & 0.0\end{array}$ $\begin{array}{lllllll}1980 & 27.9 & 16.5 & 8.5 & 2.9 & 0.0\end{array}$ $\begin{array}{llllll}1981 & 29.3 & 17.3 & 9.4 & 2.6 & 0.0\end{array}$ $\begin{array}{lllllll}1982 & 26.9 & 15.3 & 9.8 & 1.7 & 0.0\end{array}$ $\begin{array}{lllllll}1983 & 26.5 & 14.3 & 10.2 & 2.0 & 0.0\end{array}$ $\begin{array}{llllll}1984 & 27.0 & 14.2 & 10.5 & 2.3 & 0.0\end{array}$ $\begin{array}{lllllll}1985 & 27.0 & 14.3 & 10.5 & 2.1 & 0.0\end{array}$ $\begin{array}{llllll}1986 & 27.0 & 14.2 & 10.7 & 2.1 & 0.0\end{array}$ $\begin{array}{lllllll}1987 & 27.4 & 14.0 & 10.9 & 2.5 & 0.0\end{array}$ $\begin{array}{llllll}1988 & 27.4 & 13.9 & 11.2 & 2.3 & 0.0\end{array}$ $\begin{array}{lllllll}1989 & 27.7 & 14.1 & 11.3 & 2.4 & 0.0\end{array}$ $\begin{array}{lllllll}1990 & 27.9 & 13.8 & 11.8 & 2.3 & 0.0\end{array}$ $\begin{array}{llllll}1991 & 27.5 & 13.5 & 11.9 & 2.1 & 0.0\end{array}$ $\begin{array}{lllllll}1992 & 27.6 & 13.5 & 12.0 & 2.1 & 0.0\end{array}$ $\begin{array}{llllll}1993 & 28.0 & 13.6 & 12.0 & 2.5 & 0.0\end{array}$ $\begin{array}{llllll}1994 & 28.7 & 13.8 & 12.2 & 2.6 & 0.0\end{array}$ $\begin{array}{lllllll}1995 & 28.9 & 14.2 & 11.9 & 2.8 & 0.0\end{array}$ $\begin{array}{llllll}1996 & 29.0 & 14.5 & 11.6 & 2.9 & 0.0\end{array}$ $\begin{array}{lllllll}1997 & 28.8 & 14.6 & 11.4 & 2.8 & 0.0\end{array}$ $\begin{array}{llllll}1998 & 28.5 & 14.6 & 11.3 & 2.6 & 0.0\end{array}$ $\begin{array}{llllll}1999 & 28.8 & 14.9 & 11.2 & 2.6 & 0.0\end{array}$ $\begin{array}{lllllll}2000 & 28.7 & 15.1 & 11.1 & 2.5 & 0.0\end{array}$ $\begin{array}{llllll}2001 & 27.7 & 14.2 & 11.7 & 1.8 & 0.0\end{array}$

P99-99.5

All Indiv. Payroll Corp. Estate $\begin{array}{llllll}1960 & 23.5 & 14.9 & 1.7 & 6.3 & 0.6\end{array}$ $\begin{array}{lllllll}1962 & 25.5 & 15.3 & 1.9 & 7.8 & 0.6\end{array}$ $\begin{array}{llllll}1964 & 24.6 & 14.1 & 1.7 & 8.1 & 0.6\end{array}$ $\begin{array}{lllllll}1966 & 25.4 & 13.8 & 2.7 & 8.3 & 0.6\end{array}$ $\begin{array}{lllllll}1967 & 24.5 & 13.9 & 2.7 & 7.4 & 0.6\end{array}$ $\begin{array}{lllllll}1968 & 26.9 & 15.8 & 2.6 & 7.9 & 0.6\end{array}$ $\begin{array}{llllll}1969 & 26.9 & 16.2 & 3.0 & 7.1 & 0.6\end{array}$ $\begin{array}{llllll}1970 & 25.6 & 16.1 & 3.0 & 5.7 & 0.7\end{array}$ $\begin{array}{llllll}1971 & 24.4 & 14.8 & 3.1 & 5.9 & 0.7\end{array}$ $\begin{array}{lllllll}1972 & 25.5 & 15.8 & 3.3 & 5.8 & 0.6\end{array}$ $\begin{array}{lllllll}1973 & 27.5 & 16.5 & 3.9 & 6.6 & 0.5\end{array}$ $\begin{array}{llllll}1974 & 27.1 & 16.1 & 4.5 & 6.0 & 0.5\end{array}$ $\begin{array}{llllll}1975 & 27.5 & 17.1 & 4.7 & 5.3 & 0.5\end{array}$ $\begin{array}{llllll}1976 & 27.7 & 16.6 & 4.7 & 5.8 & 0.6\end{array}$ $\begin{array}{llllll}1977 & 27.5 & 16.5 & 4.6 & 6.0 & 0.4\end{array}$ $\begin{array}{llllll}1978 & 27.0 & 15.8 & 4.7 & 6.2 & 0.4\end{array}$ $\begin{array}{lllllll}1979 & 30.5 & 19.0 & 5.5 & 5.6 & 0.4\end{array}$ $\begin{array}{llllll}1980 & 31.0 & 20.1 & 5.7 & 4.8 & 0.4\end{array}$ $\begin{array}{lllllll}1981 & 31.6 & 20.8 & 6.6 & 3.9 & 0.4\end{array}$ $\begin{array}{llllll}1982 & 28.5 & 18.7 & 6.9 & 2.6 & 0.3\end{array}$ $\begin{array}{lllllll}1983 & 27.5 & 17.2 & 7.2 & 2.9 & 0.3\end{array}$ $\begin{array}{llllll}1984 & 28.0 & 17.1 & 7.4 & 3.2 & 0.3\end{array}$ $\begin{array}{llllll}1985 & 27.8 & 17.2 & 7.4 & 3.0 & 0.3\end{array}$ $\begin{array}{lllllll}1986 & 27.6 & 17.0 & 7.3 & 3.1 & 0.2\end{array}$ $\begin{array}{lllllll}1987 & 29.1 & 17.7 & 7.5 & 3.6 & 0.2\end{array}$ $\begin{array}{lllllll}1988 & 28.5 & 17.3 & 7.5 & 3.5 & 0.3\end{array}$ $\begin{array}{llllll}1989 & 28.7 & 17.4 & 7.5 & 3.5 & 0.3\end{array}$ $\begin{array}{llllll}1990 & 28.6 & 17.0 & 8.1 & 3.3 & 0.3\end{array}$ $\begin{array}{lllllll}1991 & 28.4 & 16.8 & 8.2 & 3.1 & 0.3\end{array}$ $\begin{array}{lllllll}1992 & 28.8 & 17.1 & 8.3 & 3.1 & 0.3\end{array}$ $\begin{array}{llllll}1993 & 29.5 & 17.3 & 8.4 & 3.5 & 0.3\end{array}$ $\begin{array}{llllll}1994 & 30.7 & 17.5 & 9.0 & 3.8 & 0.3\end{array}$ $\begin{array}{lllllll}1995 & 31.2 & 18.1 & 8.6 & 4.1 & 0.3\end{array}$ $\begin{array}{llllll}1996 & 31.4 & 18.6 & 8.2 & 4.1 & 0.4\end{array}$ $\begin{array}{lllllll}1997 & 30.9 & 18.4 & 8.0 & 4.1 & 0.4\end{array}$ $\begin{array}{llllll}1998 & 30.9 & 18.8 & 7.8 & 3.9 & 0.4\end{array}$ $\begin{array}{llllll}1999 & 31.2 & 19.4 & 7.6 & 3.8 & 0.4\end{array}$ $\begin{array}{llllll}2000 & 31.1 & 19.6 & 7.5 & 3.6 & 0.4\end{array}$ $\begin{array}{lllllll}2001 & 29.8 & 18.5 & 8.3 & 2.7 & 0.3\end{array}$ $\begin{array}{llllll}960 & 34.0 & 18.6 & 0.7 & 11.6 & 3.1\end{array}$ $\begin{array}{llllll}1962 & 35.8 & 19.0 & 0.8 & 12.9 & 3.0\end{array}$ $\begin{array}{llllll}1964 & 35.1 & 17.6 & 0.7 & 13.3 & 3.4\end{array}$ $\begin{array}{lllllll}1966 & 36.1 & 17.8 & 1.3 & 13.8 & 3.2\end{array}$ $\begin{array}{lllllll}1967 & 34.1 & 17.8 & 1.2 & 12.0 & 3.0\end{array}$ $\begin{array}{lllllll}1968 & 37.6 & 20.3 & 1.0 & 13.1 & 3.1\end{array}$ $\begin{array}{llllll}1969 & 37.1 & 20.3 & 1.5 & 12.2 & 3.1\end{array}$ $\begin{array}{llllll}1970 & 36.1 & 20.7 & 1.5 & 10.0 & 3.8\end{array}$ $\begin{array}{llllll}1971 & 34.3 & 18.7 & 1.6 & 9.9 & 4.1\end{array}$ $\begin{array}{lllllll}1972 & 35.5 & 20.6 & 1.6 & 9.8 & 3.5\end{array}$ $\begin{array}{lllllll}1973 & 36.6 & 21.6 & 2.1 & 10.0 & 3.0\end{array}$ $\begin{array}{lllllll}1974 & 35.3 & 20.7 & 2.3 & 9.5 & 2.7\end{array}$ $\begin{array}{llllll}1975 & 36.6 & 22.5 & 2.5 & 8.7 & 3.0\end{array}$ $\begin{array}{llllll}1976 & 36.8 & 21.5 & 2.5 & 9.3 & 3.5\end{array}$ $\begin{array}{llllll}1977 & 37.0 & 22.7 & 2.5 & 9.5 & 2.3\end{array}$ $\begin{array}{lllllll}1978 & 35.3 & 21.2 & 2.6 & 9.3 & 2.1\end{array}$ $\begin{array}{llllll}1979 & 38.1 & 24.2 & 3.0 & 8.7 & 2.2\end{array}$ $\begin{array}{llllll}1980 & 37.6 & 25.1 & 3.1 & 7.2 & 2.1\end{array}$ $\begin{array}{llllll}1981 & 37.4 & 25.6 & 3.7 & 5.9 & 2.2\end{array}$ $\begin{array}{llllll}1982 & 33.0 & 23.5 & 3.9 & 4.0 & 1.6\end{array}$ $\begin{array}{lllllll}1983 & 31.2 & 21.2 & 4.0 & 4.5 & 1.5\end{array}$ $\begin{array}{llllll}1984 & 31.6 & 21.2 & 4.2 & 4.8 & 1.5\end{array}$ $\begin{array}{llllll}1985 & 30.9 & 20.8 & 4.1 & 4.6 & 1.5\end{array}$ $\begin{array}{llllll}1986 & 30.8 & 20.8 & 3.9 & 4.7 & 1.4\end{array}$ $\begin{array}{llllll}1987 & 33.0 & 22.1 & 4.1 & 5.5 & 1.3\end{array}$ $\begin{array}{lllllll}1988 & 31.8 & 21.5 & 3.8 & 5.3 & 1.3\end{array}$ $\begin{array}{llllll}1989 & 32.0 & 21.4 & 3.9 & 5.2 & 1.6\end{array}$ $\begin{array}{llllll}1990 & 31.5 & 21.1 & 4.2 & 4.9 & 1.4\end{array}$ $\begin{array}{lllllll}1991 & 31.6 & 21.2 & 4.5 & 4.5 & 1.4\end{array}$ $\begin{array}{llllll}1992 & 32.6 & 21.8 & 4.4 & 4.8 & 1.5\end{array}$ $\begin{array}{lllllll}1993 & 34.3 & 22.6 & 4.5 & 5.5 & 1.7\end{array}$ $\begin{array}{llllll}1994 & 36.0 & 23.0 & 5.6 & 5.9 & 1.5\end{array}$ $\begin{array}{llllll}1995 & 37.3 & 24.0 & 5.2 & 6.4 & 1.7\end{array}$ $\begin{array}{llllll}1996 & 37.5 & 24.7 & 4.9 & 6.1 & 1.8\end{array}$ $\begin{array}{llllll}1997 & 36.2 & 23.6 & 4.7 & 5.9 & 2.0\end{array}$ $\begin{array}{lllllll}1998 & 36.2 & 23.9 & 4.6 & 5.6 & 2.1\end{array}$ $\begin{array}{llllll}1999 & 36.3 & 24.5 & 4.5 & 5.4 & 1.9\end{array}$ $\begin{array}{llllll}2000 & 35.7 & 24.4 & 4.3 & 5.2 & 1.7\end{array}$ $\begin{array}{lllllll}2001 & 34.8 & 24.2 & 5.1 & 3.9 & 1.6\end{array}$ 
Table A3. Average Tax Rates by Income Groups, 1960-2004 (continued 5)

\section{P99.5-99.9}

All Indiv. Payroll Corp. Estate $\begin{array}{llllll}1960 & 41.4 & 22.9 & 0.4 & 13.4 & 4.7\end{array}$ $\begin{array}{lllllll}1962 & 43.4 & 23.4 & 0.5 & 14.9 & 4.6\end{array}$ $\begin{array}{llllll}1964 & 43.6 & 22.2 & 0.4 & 15.7 & 5.2\end{array}$ $\begin{array}{llllll}1966 & 43.4 & 22.4 & 0.8 & 15.3 & 4.9\end{array}$ $\begin{array}{lllllll}1967 & 41.4 & 22.0 & 0.7 & 14.1 & 4.5\end{array}$ $\begin{array}{llllll}1968 & 45.7 & 24.8 & 0.6 & 15.6 & 4.8\end{array}$ $\begin{array}{lllllll}1969 & 44.7 & 24.6 & 0.9 & 14.5 & 4.8\end{array}$ $\begin{array}{llllll}1970 & 44.6 & 25.8 & 0.9 & 12.0 & 5.8\end{array}$ $\begin{array}{llllll}1971 & 42.8 & 23.4 & 1.0 & 12.1 & 6.4\end{array}$ $\begin{array}{lllllll}1972 & 42.9 & 25.3 & 1.1 & 11.0 & 5.5\end{array}$ $\begin{array}{llllll}1973 & 43.5 & 26.1 & 1.3 & 11.5 & 4.7\end{array}$ $\begin{array}{lllllll}1974 & 42.0 & 25.5 & 1.5 & 10.8 & 4.2\end{array}$ $\begin{array}{llllll}1975 & 43.6 & 27.7 & 1.6 & 9.7 & 4.6\end{array}$ $\begin{array}{llllll}1976 & 43.7 & 26.2 & 1.6 & 10.4 & 5.4\end{array}$ $\begin{array}{lllllll}1977 & 44.0 & 28.3 & 1.6 & 10.6 & 3.5\end{array}$ $\begin{array}{llllll}1978 & 41.7 & 26.3 & 1.7 & 10.4 & 3.3\end{array}$ $\begin{array}{llllll}1979 & 43.7 & 28.6 & 1.9 & 9.8 & 3.5\end{array}$ $\begin{array}{llllll}1980 & 43.0 & 29.4 & 1.9 & 8.3 & 3.3\end{array}$ $\begin{array}{llllll}1981 & 41.9 & 29.4 & 2.3 & 6.9 & 3.4\end{array}$ $\begin{array}{llllll}1982 & 36.8 & 27.2 & 2.4 & 4.8 & 2.4\end{array}$ $\begin{array}{llllll}1983 & 35.2 & 25.0 & 2.4 & 5.5 & 2.3\end{array}$ $\begin{array}{llllll}1984 & 35.2 & 24.5 & 2.5 & 6.0 & 2.2\end{array}$ $\begin{array}{llllll}1985 & 34.9 & 24.6 & 2.3 & 5.9 & 2.2\end{array}$ $\begin{array}{llllll}1986 & 33.8 & 23.8 & 2.2 & 5.8 & 2.0\end{array}$ $\begin{array}{llllll}1987 & 36.3 & 25.7 & 2.3 & 6.4 & 1.8\end{array}$ $\begin{array}{llllll}1988 & 33.2 & 23.4 & 2.0 & 6.2 & 1.6\end{array}$ $\begin{array}{llllll}1989 & 33.4 & 23.1 & 2.1 & 6.1 & 2.0\end{array}$ $\begin{array}{llllll}1990 & 33.0 & 23.1 & 2.2 & 5.8 & 1.8\end{array}$ $\begin{array}{llllll}1991 & 34.0 & 24.1 & 2.5 & 5.5 & 1.9\end{array}$ $\begin{array}{llllll}1992 & 34.8 & 24.7 & 2.4 & 5.8 & 1.9\end{array}$ $\begin{array}{llllll}1993 & 38.6 & 27.2 & 2.5 & 6.6 & 2.2\end{array}$ $\begin{array}{lllllll}1994 & 40.4 & 27.2 & 3.8 & 7.2 & 2.1\end{array}$ $\begin{array}{llllll}1995 & 41.2 & 28.0 & 3.6 & 7.5 & 2.2\end{array}$ $\begin{array}{llllll}1996 & 41.1 & 28.1 & 3.3 & 7.3 & 2.3\end{array}$ $\begin{array}{lllllll}1997 & 39.6 & 26.9 & 3.2 & 7.0 & 2.6\end{array}$ $\begin{array}{lllllll}1998 & 39.2 & 26.9 & 3.0 & 6.6 & 2.7\end{array}$ $\begin{array}{llllll}1999 & 39.0 & 27.3 & 2.9 & 6.5 & 2.4\end{array}$ $\begin{array}{lllllll}2000 & 38.4 & 27.3 & 2.8 & 6.1 & 2.1\end{array}$ $\begin{array}{lllllll}2001 & 37.7 & 27.4 & 3.3 & 4.9 & 2.0\end{array}$
All Indiv. Payroll Corp. Estate $\begin{array}{llllll}1960 & 55.3 & 28.7 & 0.2 & 16.7 & 9.7\end{array}$ $\begin{array}{lllllll}1962 & 56.1 & 28.3 & 0.2 & 17.9 & 9.8\end{array}$ $\begin{array}{llllll}1964 & 56.9 & 26.8 & 0.2 & 18.8 & 11.1\end{array}$ $\begin{array}{llllll}1966 & 56.3 & 27.3 & 0.3 & 18.5 & 10.1\end{array}$ $\begin{array}{lllllll}1967 & 52.7 & 26.3 & 0.3 & 16.8 & 9.3\end{array}$ $\begin{array}{lllllll}1968 & 57.7 & 29.2 & 0.2 & 18.4 & 9.8\end{array}$ $\begin{array}{lllllll}1969 & 56.7 & 28.5 & 0.4 & 17.7 & 10.2\end{array}$ $\begin{array}{lllllll}1970 & 59.1 & 31.5 & 0.4 & 14.7 & 12.5\end{array}$ $\begin{array}{lllllll}1971 & 57.7 & 28.7 & 0.4 & 14.9 & 13.7\end{array}$ $\begin{array}{lllllll}1972 & 56.3 & 30.6 & 0.5 & 13.5 & 11.7\end{array}$ $\begin{array}{lllllll}1973 & 55.9 & 31.2 & 0.6 & 14.0 & 10.0\end{array}$ $\begin{array}{lllllll}1974 & 53.7 & 31.4 & 0.7 & 13.2 & 8.5\end{array}$ $\begin{array}{lllllll}1975 & 56.0 & 33.8 & 0.7 & 11.8 & 9.6\end{array}$ $\begin{array}{lllllll}1976 & 55.9 & 31.4 & 0.7 & 12.6 & 11.2\end{array}$ $\begin{array}{lllllll}1977 & 55.4 & 34.7 & 0.7 & 12.7 & 7.2\end{array}$ $\begin{array}{lllllll}1978 & 52.3 & 31.9 & 0.7 & 12.9 & 6.7\end{array}$ $\begin{array}{llllll}1979 & 53.0 & 32.7 & 0.8 & 12.7 & 6.8\end{array}$ $\begin{array}{lllllll}1980 & 51.0 & 33.4 & 0.8 & 10.4 & 6.5\end{array}$ $\begin{array}{llllll}1981 & 49.5 & 33.1 & 1.0 & 8.8 & 6.6\end{array}$ $\begin{array}{lllllll}1982 & 42.0 & 30.1 & 0.9 & 6.6 & 4.4\end{array}$ $\begin{array}{lllllll}1983 & 41.1 & 28.7 & 0.9 & 7.3 & 4.2\end{array}$ $\begin{array}{lllllll}1984 & 40.9 & 28.4 & 0.9 & 7.8 & 3.8\end{array}$ $\begin{array}{lllllll}1985 & 40.6 & 28.2 & 0.8 & 7.9 & 3.7\end{array}$ $\begin{array}{llllll}1986 & 38.7 & 26.6 & 0.7 & 7.8 & 3.6\end{array}$ $\begin{array}{lllllll}1987 & 40.4 & 29.2 & 0.9 & 7.5 & 2.8\end{array}$ $\begin{array}{lllllll}1988 & 34.5 & 24.1 & 0.6 & 7.5 & 2.2\end{array}$ $\begin{array}{llllll}1989 & 35.0 & 23.9 & 0.7 & 7.5 & 3.0\end{array}$ $\begin{array}{lllllll}1990 & 34.3 & 24.0 & 0.8 & 6.9 & 2.6\end{array}$ $\begin{array}{llllll}1991 & 36.5 & 26.1 & 0.9 & 6.6 & 2.9\end{array}$ $\begin{array}{lllllll}1992 & 36.9 & 26.5 & 0.8 & 6.9 & 2.8\end{array}$ $\begin{array}{lllllll}1993 & 43.5 & 31.0 & 0.8 & 8.2 & 3.4\end{array}$ $\begin{array}{lllllll}1994 & 45.0 & 30.8 & 2.0 & 9.1 & 3.2\end{array}$ $\begin{array}{lllllll}1995 & 45.5 & 31.0 & 1.9 & 9.3 & 3.3\end{array}$ $\begin{array}{llllll}1996 & 44.8 & 30.6 & 1.8 & 9.1 & 3.4\end{array}$ $\begin{array}{lllllll}1997 & 42.5 & 28.5 & 1.6 & 8.9 & 3.5\end{array}$ $\begin{array}{llllll}1998 & 42.0 & 28.8 & 1.6 & 8.0 & 3.5\end{array}$ $\begin{array}{llllll}1999 & 41.4 & 29.2 & 1.6 & 7.5 & 3.0\end{array}$ $\begin{array}{llllll}2000 & 40.2 & 29.0 & 1.6 & 7.1 & 26\end{array}$ $\begin{array}{llllll}2001 & 40.4 & 30.0 & 1.9 & 5.9 & 2.7\end{array}$
All Indiv. Payroll Corp. Estate $\begin{array}{llllll}1960 & 71.4 & 31.5 & 0.0 & 22.3 & 17.6\end{array}$ $\begin{array}{llllll}1962 & 70.7 & 29.4 & 0.1 & 23.0 & 18.2\end{array}$ $\begin{array}{lllllll}1964 & 71.8 & 27.8 & 0.0 & 23.6 & 20.3\end{array}$ $\begin{array}{llllll}1966 & 69.6 & 28.8 & 0.1 & 22.7 & 18.1\end{array}$ $\begin{array}{lllllll}1967 & 64.4 & 27.5 & 0.1 & 19.8 & 17.0\end{array}$ $\begin{array}{lllllll}1968 & 69.0 & 29.4 & 0.1 & 21.1 & 18.4\end{array}$ $\begin{array}{llllll}1969 & 67.6 & 27.3 & 0.1 & 21.4 & 18.9\end{array}$ $\begin{array}{lllllll}1970 & 74.6 & 32.2 & 0.1 & 19.0 & 23.4\end{array}$ $\begin{array}{llllll}1971 & 73.6 & 29.1 & 0.1 & 18.6 & 25.8\end{array}$ $\begin{array}{lllllll}1972 & 70.4 & 31.5 & 0.1 & 16.9 & 21.8\end{array}$ $\begin{array}{lllllll}1973 & 70.2 & 32.9 & 0.2 & 17.5 & 19.6\end{array}$ $\begin{array}{lllllll}1974 & 67.0 & 34.0 & 0.2 & 16.6 & 16.2\end{array}$ $\begin{array}{lllllll}1975 & 69.6 & 36.0 & 0.2 & 15.7 & 17.8\end{array}$ $\begin{array}{lllllll}1976 & 70.7 & 33.6 & 0.2 & 16.6 & 20.3\end{array}$ $\begin{array}{lllllll}1977 & 67.5 & 37.4 & 0.2 & 16.7 & 13.2\end{array}$ $\begin{array}{lllllll}1978 & 63.9 & 34.8 & 0.2 & 16.8 & 12.1\end{array}$ $\begin{array}{lllllll}1979 & 61.3 & 32.2 & 0.2 & 17.0 & 12.0\end{array}$ $\begin{array}{llllll}1980 & 59.3 & 34.9 & 0.2 & 13.3 & 11.0\end{array}$ $\begin{array}{llllll}1981 & 55.9 & 33.0 & 0.2 & 11.7 & 11.1\end{array}$ $\begin{array}{lllllll}1982 & 44.7 & 29.2 & 0.2 & 8.7 & 6.7\end{array}$ $\begin{array}{lllllll}1983 & 45.0 & 29.9 & 0.2 & 9.2 & 5.8\end{array}$ $\begin{array}{llllll}1984 & 44.5 & 29.3 & 0.2 & 10.1 & 5.0\end{array}$ $\begin{array}{llllll}1985 & 43.3 & 28.8 & 0.2 & 9.2 & 5.1\end{array}$ $\begin{array}{llllll}1986 & 39.7 & 25.6 & 0.1 & 9.3 & 4.7\end{array}$ $\begin{array}{llllll}1987 & 43.6 & 30.0 & 0.2 & 9.8 & 3.7\end{array}$ $\begin{array}{lllllll}1988 & 35.3 & 23.6 & 0.1 & 9.0 & 2.5\end{array}$ $\begin{array}{lllllll}1989 & 36.7 & 23.7 & 0.1 & 9.3 & 3.6\end{array}$ $\begin{array}{llllll}1990 & 35.4 & 23.6 & 0.1 & 8.7 & 3.1\end{array}$ $\begin{array}{lllllll}1991 & 38.1 & 26.2 & 0.2 & 8.2 & 3.6\end{array}$ $\begin{array}{lllllll}1992 & 37.9 & 26.9 & 0.1 & 7.8 & 3.1\end{array}$ $\begin{array}{lllllll}1993 & 45.9 & 31.9 & 0.2 & 9.8 & 4.0\end{array}$ $\begin{array}{lllllll}1994 & 46.9 & 31.1 & 1.0 & 11.1 & 3.8\end{array}$ $\begin{array}{lllllll}1995 & 47.5 & 31.7 & 1.0 & 10.8 & 4.0\end{array}$ $\begin{array}{lllllll}1996 & 46.5 & 31.1 & 1.0 & 10.5 & 4.0\end{array}$ $\begin{array}{lllllll}1997 & 43.8 & 29.4 & 1.1 & 9.3 & 4.0\end{array}$ $\begin{array}{llllll}1998 & 42.9 & 29.7 & 1.2 & 8.1 & 3.9\end{array}$ $\begin{array}{llllll}1999 & 42.0 & 30.4 & 1.3 & 7.1 & 3.2\end{array}$ $\begin{array}{lllllll}2000 & 40.8 & 30.1 & 1.3 & 6.6 & 2.7\end{array}$ $\begin{array}{llllll}2001 & 41.3 & 30.9 & 1.4 & 6.0 & 3.0\end{array}$ 
Table A4. Aggregate Income and Tax Rates for International Comparisons

\begin{tabular}{|c|c|c|c|c|c|c|}
\hline & \multicolumn{2}{|c|}{ United States } & \multicolumn{2}{|c|}{ United Kingdom } & \multicolumn{2}{|c|}{ France } \\
\hline & 1970 & 2004 & 1970 & 2000 & 1970 & 2005 \\
\hline \multicolumn{7}{|l|}{ A. Aggregates Estimates used in the study } \\
\hline Tax unit type & Family & Family & Family & Individual & Family & Family \\
\hline Total number of units ('000s) & 79,924 & 143,982 & 28,206 & 47,652 & 21,033 & 36,793 \\
\hline Total nominal personal income & 706,353 & $7,202,824$ & 36,104 & 701,771 & 76,708 & $1,200,050$ \\
\hline Pre-tax real income per tax unit & 43,021 & 50,026 & 13,926 & 14,727 & 22,103 & 32,616 \\
\hline \multicolumn{7}{|l|}{ Post-tax real income per tax unit } \\
\hline Individual income tax rate & $12.52 \%$ & $11.47 \%$ & $17.06 \%$ & $15.04 \%$ & $5.33 \%$ & $3.80 \%$ \\
\hline Payroll tax rate & $5.80 \%$ & $9.26 \%$ & $7.00 \%$ & $8.31 \%$ & $20.85 \%$ & $33.35 \%$ \\
\hline Corporate tax rate & $4.33 \%$ & $2.27 \%$ & & & & \\
\hline Estate and wealth tax rate & $0.65 \%$ & $0.36 \%$ & $1.06 \%$ & $0.34 \%$ & $0.26 \%$ & $0.70 \%$ \\
\hline Total tax rate (included in the study) & $23.30 \%$ & $23.36 \%$ & $25.12 \%$ & $23.69 \%$ & $26.44 \%$ & $37.85 \%$ \\
\hline \multicolumn{7}{|l|}{ B. Average tax rates from $O E C D$ statistics } \\
\hline Year & 1970 & 2003 & 1970 & 2000 & 1970 & 2003 \\
\hline Individual income tax rate & $14.34 \%$ & $13.72 \%$ & $16.66 \%$ & $14.88 \%$ & $5.93 \%$ & $4.01 \%$ \\
\hline Payroll tax rate & $6.30 \%$ & $10.26 \%$ & $9.71 \%$ & $8.59 \%$ & $20.73 \%$ & $29.14 \%$ \\
\hline Estate and wealth tax rate & $0.66 \%$ & $0.39 \%$ & $1.06 \%$ & $0.32 \%$ & $0.40 \%$ & $0.81 \%$ \\
\hline Corporate tax rate & $5.18 \%$ & $3.13 \%$ & $4.68 \%$ & $4.94 \%$ & $3.53 \%$ & $3.30 \%$ \\
\hline Consumption tax rate (excise, sales, and value added te & $7.82 \%$ & $7.07 \%$ & $15.21 \%$ & $16.26 \%$ & $21.09 \%$ & $14.65 \%$ \\
\hline Property tax rate (excluding estate and individual wealtr & $4.89 \%$ & $4.31 \%$ & $5.53 \%$ & $5.51 \%$ & $2.25 \%$ & $3.39 \%$ \\
\hline Other taxes & $0.00 \%$ & $0.00 \%$ & $0.00 \%$ & $0.00 \%$ & $1.38 \%$ & $2.05 \%$ \\
\hline Total tax rate (including all taxes) & $39.18 \%$ & $38.89 \%$ & $52.85 \%$ & $50.50 \%$ & $55.30 \%$ & $57.35 \%$ \\
\hline Fraction of all taxes included in the study & $59.48 \%$ & $60.07 \%$ & $47.53 \%$ & $46.91 \%$ & $47.80 \%$ & $66.00 \%$ \\
\hline
\end{tabular}

Notes: Computations are based on tax statistics and author's computations.

OECD tax statistics are based on OECD (2005), Revenue Statistics, 1965-2004.

Nominal taxes reported in the OECD publication are divided by total nominal personal income estimated in the study.

Tax units in the United States and France are based on families. Tax units in the United Kingdom are based on families in 1970 and on individual adults in 2000.

Nominal incomes are reported in Millions of dollars for the US, Millions of pounds for the UK, and Millions of Euros for France.

Individual income in all three countries includes all payroll taxes. Realized capital gains are included in France and the US but not the UK.

Corporate income taxes are not included in income or tax computations in France and the United Kingdom.

In the United States, OECD tax statistics include federal, state, and local taxes while study includes only federal taxes.

In France, individual income tax includes only the progressive individual income tax. The flat income tax (CSG and RDS) is included in payroll taxes. 
Table A5. Income and Tax Rate Statistics for France

\begin{tabular}{|c|c|c|c|c|c|c|c|c|}
\hline \multirow[b]{2}{*}{$\begin{array}{c}\text { Income Groups } \\
\text { (1) } \\
\end{array}$} & \multirow[b]{2}{*}{$\begin{array}{c}\text { Average } \\
\text { Income (pre } \\
\text { tax) in real } \\
2005 \text { Euros } \\
(2)\end{array}$} & \multicolumn{5}{|c|}{ Average tax rates (percent) } & \multicolumn{2}{|c|}{ Income shares } \\
\hline & & $\begin{array}{c}\text { Individual } \\
\text { Income } \\
\text { Tax } \\
(3) \\
\end{array}$ & $\begin{array}{c}\text { Payroll } \\
\text { Taxes } \\
(4) \\
\end{array}$ & $\begin{array}{c}\text { Estate } \\
\text { Tax } \\
(5) \\
\end{array}$ & $\begin{array}{c}\text { Progressive } \\
\text { Wealth Tax } \\
(6)\end{array}$ & $\begin{array}{c}\text { Total } \\
\text { Direct } \\
\text { Taxes } \\
(7) \\
\end{array}$ & $\begin{array}{c}\text { Pre-tax } \\
\text { income } \\
\text { share } \\
(8) \\
\end{array}$ & $\begin{array}{c}\text { Post-tax } \\
\text { income } \\
\text { share } \\
(9) \\
\end{array}$ \\
\hline \multicolumn{9}{|l|}{ A. Year 1970} \\
\hline \multicolumn{9}{|l|}{ (21.0 million families) } \\
\hline P0-90 & $€ 17,020$ & 2.3 & 24.0 & 0.0 & 0.0 & 26.3 & 69.30 & 69.39 \\
\hline P90-95 & $€ 47,073$ & 6.4 & 17.6 & 0.2 & 0.0 & 24.2 & 10.65 & 10.97 \\
\hline P95-99 & $€ 69,144$ & 10.6 & 14.1 & 0.4 & 0.0 & 25.1 & 12.51 & 12.74 \\
\hline P99-99.5 & $€ 114,374$ & 16.8 & 10.6 & 0.8 & 0.0 & 28.2 & 2.59 & 2.52 \\
\hline P99.5-99.9 & $€ 170,477$ & 21.9 & 7.4 & 1.9 & 0.0 & 31.2 & 3.09 & 2.88 \\
\hline P99.9-99.99 & $€ 335,622$ & 30.2 & 4.2 & 4.2 & 0.0 & 38.6 & 1.37 & 1.14 \\
\hline P99.99-100 & $€ 1,095,678$ & 40.1 & 1.7 & 6.9 & 0.0 & 48.8 & 0.50 & 0.35 \\
\hline \multicolumn{9}{|l|}{ B. Year 2005} \\
\hline $\begin{array}{c}\text { Full Population } \\
\text { (36.8 million families) }\end{array}$ & $€ 38,665$ & 3.8 & 33.3 & 0.5 & 0.2 & 37.8 & 100.0 & 100.0 \\
\hline P0-90 & $€ 29,612$ & 1.8 & 34.8 & 0.1 & 0.0 & 36.7 & 68.93 & 70.19 \\
\hline P90-95 & $€ 89,486$ & 4.5 & 33.7 & 0.6 & 0.0 & 38.8 & 11.57 & 11.39 \\
\hline P95-99 & $€ 124,156$ & 7.0 & 31.4 & 1.4 & 0.0 & 39.8 & 12.84 & 12.44 \\
\hline P99-99.5 & $€ 182,681$ & 11.6 & 26.5 & 2.1 & 0.1 & 40.3 & 2.36 & 2.27 \\
\hline P99.5-99.9 & $€ 258,371$ & 16.4 & 21.4 & 3.0 & 2.1 & 43.0 & 2.67 & 2.45 \\
\hline P99.9-99.99 & $€ 512,979$ & 22.3 & 16.5 & 4.8 & 4.1 & 47.8 & 1.19 & 1.00 \\
\hline P99.99-100 & $€ 1,645,885$ & 28.8 & 8.5 & 7.6 & 16.6 & 61.5 & 0.43 & 0.26 \\
\hline
\end{tabular}

Notes: Computations are based on income tax return statistics analyzed in Piketty (2001).

Year 2005 computations are based on incomes from 1998 adjusted for growth and using 2005 tax law.

Families are ranked based on market income excluding realized capital gains.

Average income includes realized capital gains and imputed payroll taxes. Tax rates are estimated

relative to income including realized capital gains and imputed payroll taxes. 


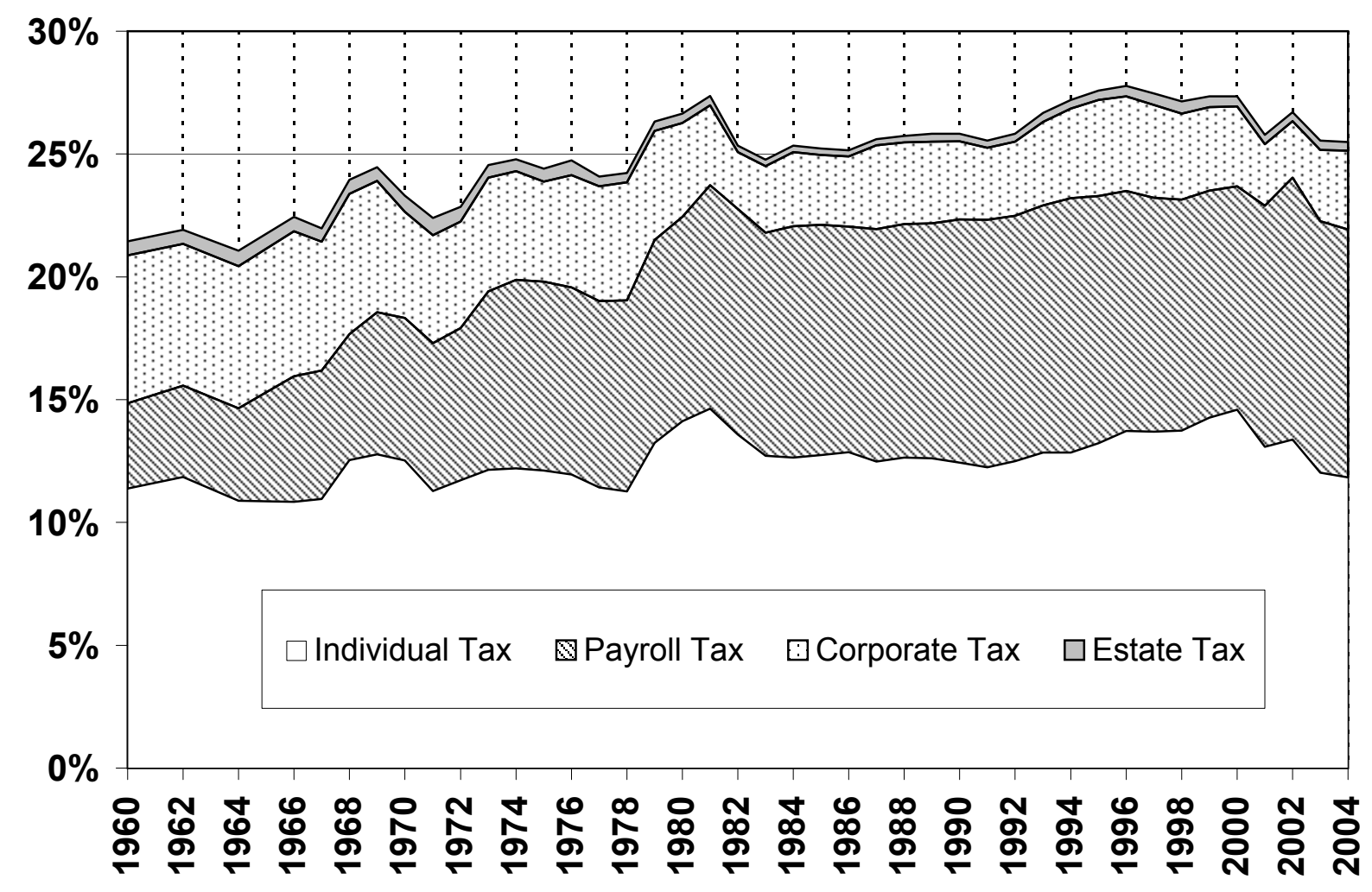

FIGURE A1

Average tax rates, 1960-2004

Figure displays the average tax rate for each of the 4 federal taxes for the full population.

Realized capital gains and corporate tax are added back to income when computing tax rates

Payroll taxes include employer+employee Social Security and Medicare taxes 


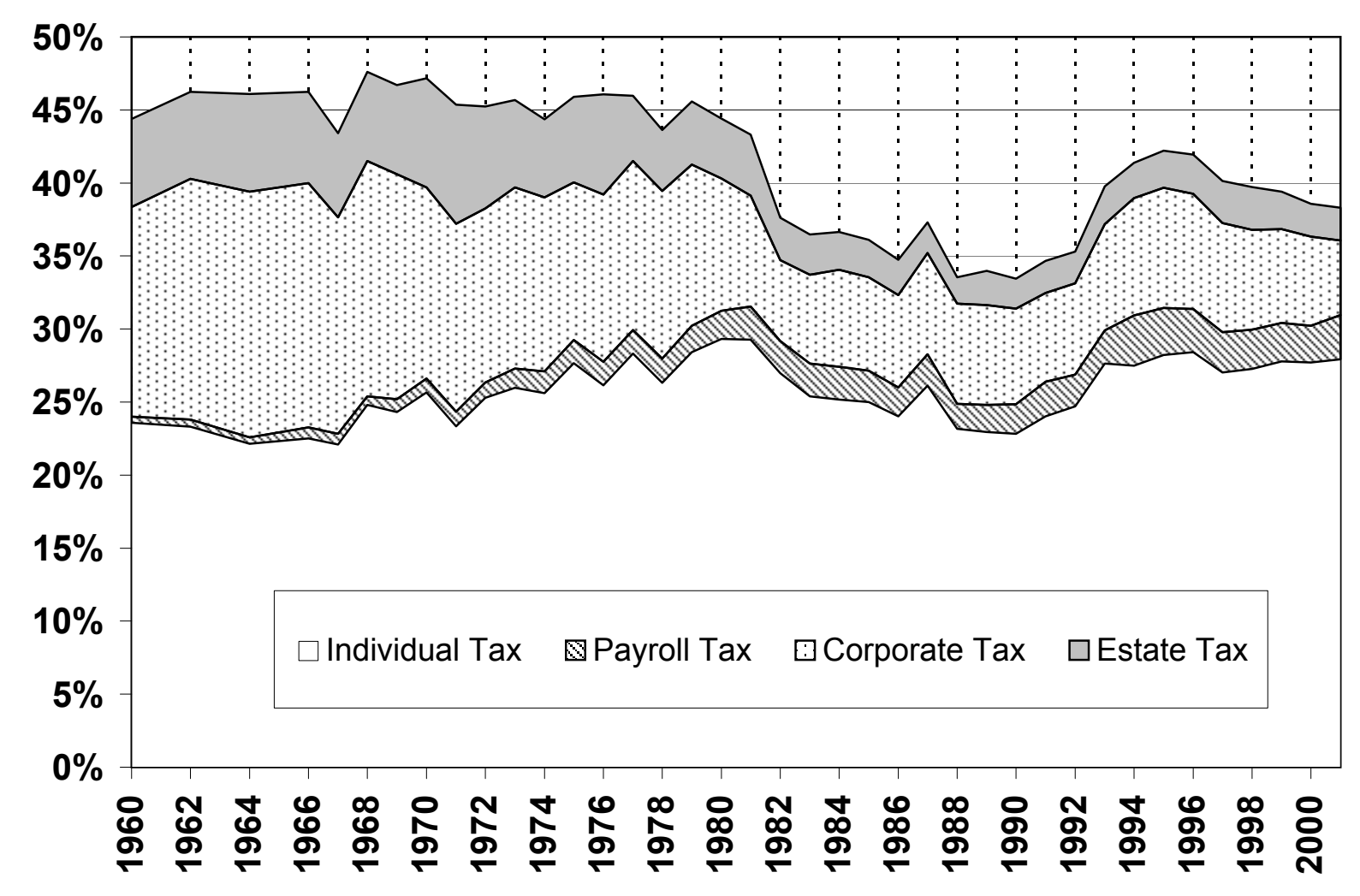

FIGURE A2

The Top 1\% tax rates, 1960-2001

Source: Table A3 


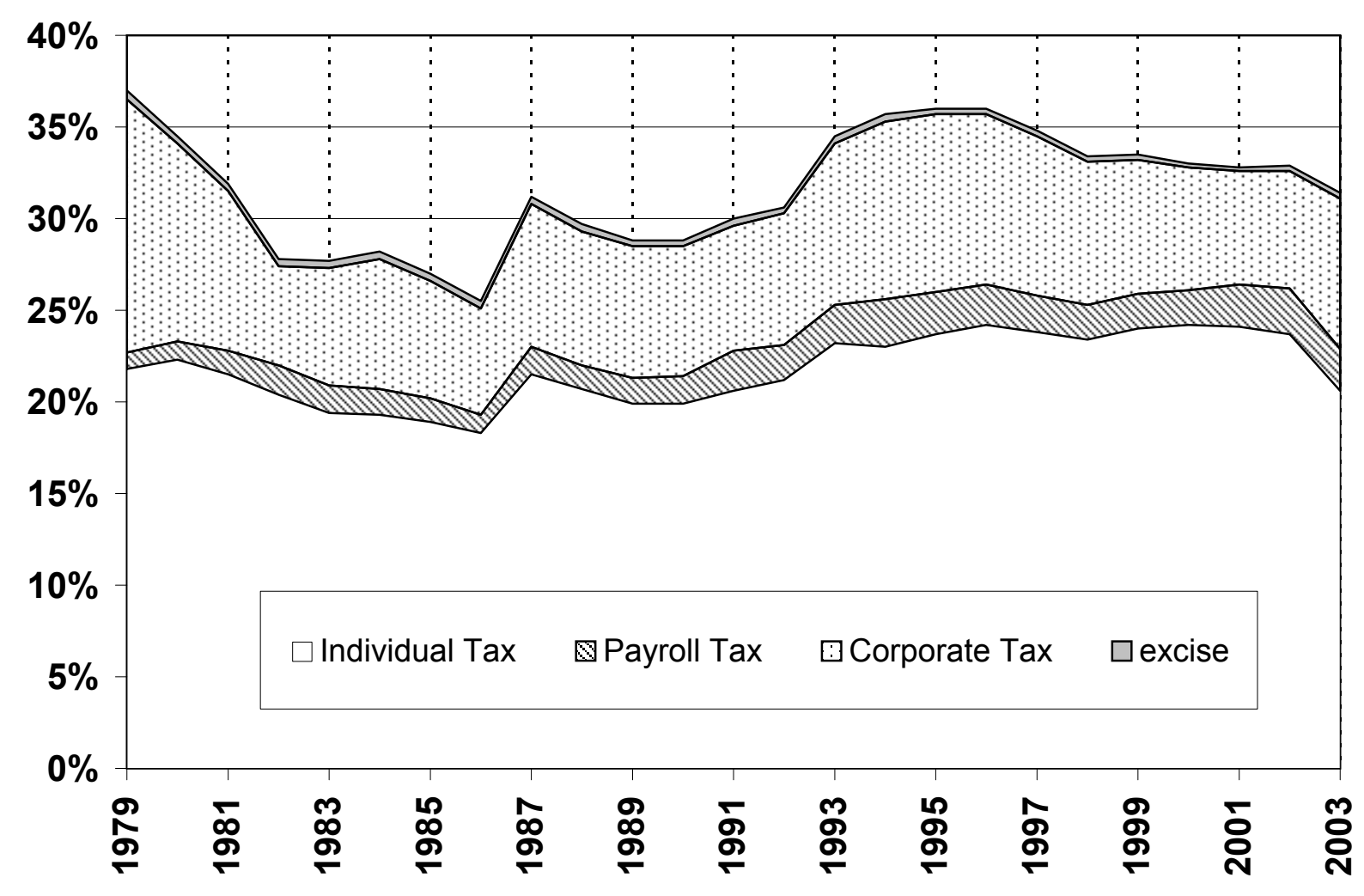

FIGURE A3

The Top $1 \%$ tax rates, CBO estimates, 1979-2003

Source: CBO (2001) updated to 2003 